\title{
MÉTODO CONCILIADO PARA AVALIAR OS EFEITOS DA COLONIZAÇÃO DE COLMOS DE CANA-DE-AÇÚCAR POR Clavibacter xyli subsp. xyli NA FUNCIONALIDADE DO XILEMA
}

\author{
ÉDER ANTÔNIO GIGLIOTI \\ Engenheiro Agrônomo
}

ORIENTADOR: Professor Dr. HASIME TOKESHI

Tese apresentada à Escola Superior de Agricultura "Luiz de Queiroz", Universidade de São Paulo, para obtenção do, título de Doutor em Agronomia, Área de Concentração: Fitopatologia.

PIR A C I C A B A

Estado de São Paulo - Brasil

Novembro - 1997 
Dados Internacionais de Catalogação na Publicação (CIP) DIVISĀO DE BIBLIOTECA E DOCUMENTAÇĀO - Campus "Luiz de Queiroz"/USP

Giglioti, Éder Antônio

Método conciliado para avaliar os efeitos da colonização de colmos de cana-deaçucar por Clavibacter xyli subsp. xyli na funcionalidade do xilema / Éder Antônio Giglioti. - - Piracicaba, 1997.

134 p. : il.

Tese (doutorado) - - Escola Superior de Agricultura Luiz de Queiroz, 1997. Bibliografia.

1. Bacteria fitopatogênica 2. Cana-de-açúcar 3. Colonização de planta 4. Raquitismo-das-soqueiras-da-cana 5. Resistência a doença 6. Xilema I. Titulo

CDD 633.61 


\section{MÉTODO CONCILIADO PARA AVALIAR OS EFEITOS DA COLONIZAÇÃO DE COLMOS DE CANA-DE-AÇÚCAR POR Clavibacter $x y l i$ subsp. $x y l i$ NA FUNCIONALIDADE DO XILEMA}

\section{ÉDER ANTÔNIO GIGLIOTI}

Aprovada em: 15.12.1997

Comissão julgadora:

Prof. Dr. Hasime Tokeshi

ESALQ/USP

Prof. Dr. Modesto Barreto

FCAV/UNESP

Prof. Dr. Sérgio Florentino Pascholati

ESALQ/USP

Prof. Dr. Sizuo Matsuoka

CCA/UFSCar

Dr. Álvaro Sanguino

COPERSUCAR

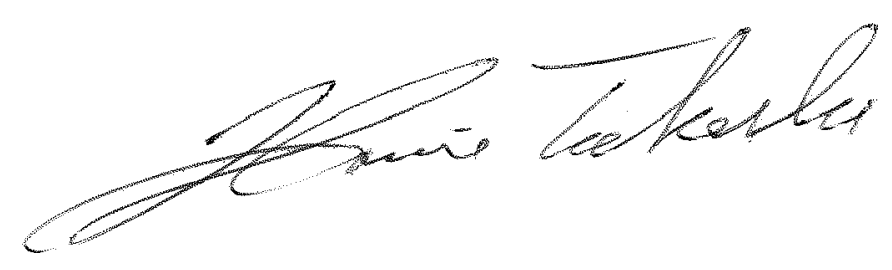

Prof. Dr. HASIME TOKESHI

ORIENTADOR 
À memória de minha mãe; ao meu pai e irmãos

Dedico. 


\section{AGRADECIMENTOS}

A todos que colaboraram na realização deste trabalho, e em especial:

- Ao Prof. Dr. Hasime Tokeshi, pela orientação, estímulo e sobretudo amizade;

- Aos professores do Departamento de Fitopatologia da ESALQ/USP, pelos ensinamentos;

- Ao Programa de Melhoramento Genético da Cana-de-açúcar do Centro de Ciências Agrárias/UFSCar, pela liberação para a realização do curso de Pósgraduação e pelo suporte financeiro às tarefas executadas nos EUA;

- Aos Drs. Jack C. Comstock (USDA-ARS, Sugarcane Field Station, Canal Point, FL), Michael J. Davis (University of Florida, Tropical Research and Education Center, Homestead, FL) e Michael P. Grisham (USDA-ARS, U.S. Sugarcane Research Unit, Houma, LA), que tornaram possível a realização deste trabalho. 
- Aos Professores Dr. Sizuo Matsuoka e Dr. Yodiro Masuda do Centro de Ciências Agrárias da UFSCar, Araras, SP, por suas sugestões e auxílio durante a execução deste trabalho;

- Ao colega Engenheiro Agrônomo Antonio Augusto Franco Garcia pelas sugestões e auxílio nas análises estatísticas; e

- Aos colegas e funcionários dos Departamentos de Fitopatologia da ESALQ/USP e de Biotecnologia Vegetal do CCA/UFSCar, pelo constante estímulo no decorrer do curso de doutorado. 


\section{SUMÁRIO}

Página

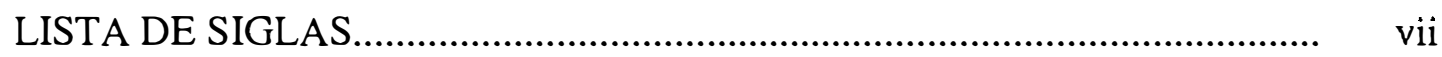

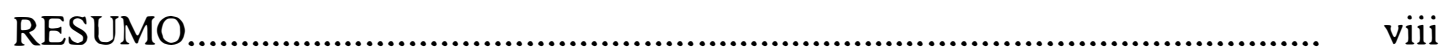

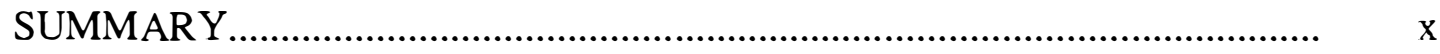

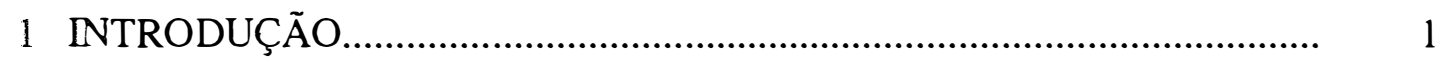

2 REVIS ÃO DE LITERATURA............................................................ 5

2.1 História e importância do Raquitismo-da-soqueira (RS)..................... 5

$2.2 \quad$ Etiologia.......................................................................... 7

2.3 Sintomas e fatores que afetam sua expressão....................................... 8

$2.4 \quad$ Métodos de diagnose do RS ............................................................ 10

2.5 Menor eficiência no transporte de água e sais minerais: alteração fisiológica no hospedeiro induzida por $C$. $x$. subsp. $x y l i \ldots \ldots \ldots \ldots \ldots \ldots \ldots . . . . . . . . . .12$

2.6 Ciclo das relações Clavibacter xyli subsp. xyli-cana-de-açúcar........... 15

2.6.1 Sobrevivência...................................................................................... 15

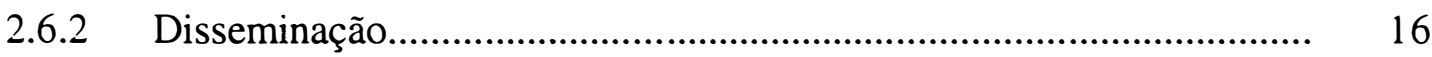

2.6.3 Infecção, colonização e reprodução....................................................... 19

$2.7 \quad$ Medidas de controle do RS................................................................ 20

2.7.1 Descontaminação de ferramentas.......................................................... 21

2.7.2 Produção de mudas sadias................................................................. 22

2.7.3 Uso de cultivares resistentes.......................................................... 25

2.8 Métodos utilizados para a identificação de genótipos resistentes ou

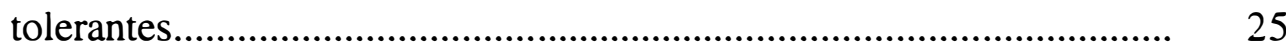

2.8.1 Diferença de produção entre parcelas sadias e doentes e resistência ao RS (Dados de Produção = DP) ....................................................... 27

2.8.2 Anatomia vascular como fator determinante da resistência................. 30

2.8.3 Funcionalidade dos vasos do xilema e resistência ao RS..................... 32 
2.8.4 Resistência de cana-de-açúcar à infecção por $C . \quad x$. subsp. xyli.

2.8.5 Resistência de cana-de-açúcar à colonização por $C$. $x$. subsp. xyli.

3 MATERIAL E MÉTODOS.

3.1 Padronização de método para avaliar a colonização de colmos de cana-de-açúcar por $C$. $x$. subsp. xyli e o respectivo efeito na funcionalidade dos vasos do xilema

3.1.1 Método conciliado MCVX/TBIA........................................................ 43

3.1.1.1 Protocolo MCVX/TBIA................................................................ 43

3.1.1.2 Influência da safranina $O$ na deteç̧ão de vasos colonizados pelo método conciliado MCVX/TBIA.

3.1.1.3 Repetibilidade dos resultados obtidos pelo método conciliado

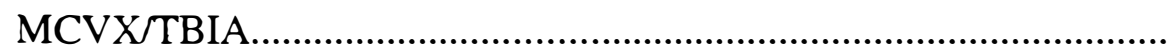

3.1.2 Tamanho da amostra para avaliar a severidade do RS em seç̧ões transversais de colmos de cana-de-açúcar.

3.1.3 Parâmetro que melhor representa a severidade do RS em colmos de cana-de-açúcar.

3.2 Efeitos da colonização de colmos de cana-de-açúcar por $C$. $x$. subsp. xyli na funcionalidade dos vasos do xilema de cultivares diferindo em suscetibilidade ao RS

3.2.1 Padrão de colonização de feixes vasculares por $C$. $x$. subsp. xyli em secções transversais de colmos de cana-de-açúcar.

3.2.2 Relação entre colonização e entupimento dos vasos do xilema de colmos de cana-de-açúcar por $C . x$. subsp. xyli.

3.3 Eficácia dos métodos MCVX e TBIA para identificação de genótipos de cana-de-açúcar resistentes ou tolerantes ao RS...

3.3.1 Identificação de genótipos de cana-de-açúcar resistentes ao RS..........

3.3.2 Identificação de genótipos de cana-de-açúcar tolerantes ao RS 
4.1 Padronização de método para avaliar a colonização de colmos de cana-de-açúcar por $C$. $x$. subsp. xyli e o respectivo efeito na funcionalidade dos vasos do xilema.

4.1.1 Método conciliado MCVX/TBIA........................................................ 54

4.1.1.1 Protocolo MCVX/TBIA ......................................................................... 54

4.1.1.2 Influência da safranina $O$ na detecção de vasos colonizados pelo método conciliado MCVX/TBIA

4.1.1.3 Repetibilidade dos resultados obtidos pelo método conciliado MCVX/TBIA

4.1.2 Tamanho da amostra para avaliar a severidade do RS em secções transversais de colmos de cana-de-açúcar.

4.1.3 Parâmetro que melhor representa a severidade do RS em colmos de cana-de-açúcar.

4.2 Efeitos da colonização de colmos de cana-de-açúcar por C. $x$. subsp. xyli na funcionalidade dos vasos do xilema de cultivares diferindo em suscetibilidade ao RS

4.2.1 Padrão de colonização de feixes vasculares por $C$. $x$. subsp. xyli em secções transversais de colmos de cana-de-açúcar.

4.2.2 Relação entre colonização e entupimento dos vasos do xilema de colmos de cana-de-açúcar por $C$. $x$. subsp. $x y l i$

4.3 Eficácia dos métodos MCVX e TBIA para identificação de genótipos de cana-de-açúcar resistentes ou tolerantes ao RS.

4.3.1 Identificação de genótipos de cana-de-açúcar resistentes ao RS.......... 66

4.3.2 Identificação de genótipos de cana-de-açúcar tolerantes ao RS........... 71

5 DISCUSS ÃO GERAL......................................................................

6 CONCLUSÕES 
7 REFERÊNCIAS BIBLIOGRÁFICAS

ANEXO: FIGURAS E TABELAS. 


\section{LISTA DE SIGLAS}

1. $\mathrm{DP}=$ Dados de Produção

2. MCVX $=$ Método de Coloração dos Vasos do Xilema

3. RS $=$ Raquitismo-da-soqueira

4. TBIA $=$ "Tissue Blot Enzyme Immunoassay"

5. $\mathrm{TT}=$ Tratamento Térmico

6. $\mathrm{TV}=$ Total de Vasos amostrados

7. $\quad$ VC $=$ Vasos Colonizados por Clavibacter $x y l i$ subsp. $x y l i$

8. $\% \mathrm{VC}=$ Porcentagem de Vasos Colonizados por Clavibacter xyli subsp. $x y l i$

9. $\quad$ VNF $=$ Vasos Não Funcionais

10. $\% \mathrm{VNF}=$ Porcentagem de Vasos Não Funcionais 


\title{
MÉTODO CONCILIADO PARA AVALIAR OS EFEITOS DA COLONIZAÇÃO DE COLMOS DE CANA-DE-AÇÚCAR POR Clavibacter $x y l i$ subsp. $x y l i$ NA FUNCIONALIDADE DO XILEMA
}

\author{
Autor: Éder Antônio Giglioti \\ Orientador: Prof. Dr. Hasime Tokeshi
}

\section{RESUMO}

Diagnose do Raquitismo-da-soqueira (RS) pelo método de coloração dos vasos do xilema (MCVX) e por "tissue blot enzyme immunoassay" (TBIA) foram efetuadas para se estudar a colonização de colmos de cana-de-açúcar pela bactéria Clavibacter xyli subsp. xyli e seu efeito na absorção e transporte de água pelo xilema de distintos genótipos.

MCVX coloriu os feixes vasculares funcionais, mas não os entupidos (VNF), enquanto TBIA coloriu aqueles colonizados (VC). MCVX/TBIA consiste num modelo para avaliar alterações fisiológicas induzidas no hospedeiro por bactérias habitantes do xilema. Tanto TBIA como MCVX determinaram que a distribuição de VC era mais freqüente nos tecidos do meio da secção transversal dos internódios, diminuindo progressivamente nos tecidos próximos da epiderme. Em Canal Point, Flórida (EUA), alta correlação entre VNF e VC foi obtida em um grupo de nove genótipos moderadamente resistentes $(r=0,987)$. Em um segundo experimento, usando 19 genótipos com uma gama maior de reação ao RS, a correlação entre os dois parâmetros foi menor $(\mathrm{r}=0,40)$. A razão principal para este fato foi que alguns genótipos tinham baixa \%VNF apesar de suportarem alta \%VC. Nestes genótipos, embora o patógeno estivesse presente no xilema, o transporte de água não foi completamente evitado. 
Um terceiro experimento foi conduzido em Houma, Louisiana (EUA), para verificar se os resultados do segundo experimento poderiam indicar tolerância ao RS. A correlação entre $\% \mathrm{VC}$ e $\% \mathrm{VNF}$ foi $\mathrm{r}=0,68$, mas nenhum deles esteve correlacionado com danos em produção, devido à existência de diferentes níveis de tolerância ao RS. A presença de vasos funcionais, apesar de colonizados por $C$. $x$. subsp. $x y l i$, não foi suficiente para explicar a tolerância observada em diferentes genótipos. Outros fatores além da mera prevenção no transporte de água podem contribuir para a ocorrência de danos em produção. Por outro lado, processos inatos da planta que regulam a taxa de transpiração (perda de água) e sensibilidade à prevenção no transporte de seiva bruta podem estar agindo como mecanismos de tolerância ao RS.

A alta correlação entre \%VC e \%VNF em genótipos moderadamente resistentes faz com que tanto TBIA como MCVX sejam adequados para selecionar genótipos de cana-de-açúcar resistentes ao RS nas fases iniciais de seleção. MCVX mostra-se como um método alternativo para países ainda em desenvolvimento, onde a mão de obra é mais barata e os equipamentos e reagentes requeridos pelo TBIA não são facilmente obtidos. No entanto, caso genótipos intermediários não sejam descartados nas fases iniciais da seleção, experimentos comparando a produção de parcelas sadias e doentes são necessários para determinar o nível de tolerância de cada um deles.

O conhecimento do nível de resistência e tolerância de cada genótipo, antes de sua liberação, é de capital importância para orientar a tomada de medidas fitossanitárias complementares para reduzir o inóculo das mudas (Xo) e a evolução da doença ao longo das soqueiras (r) daqueles genótipos que suportam um potencial epidêmico elevado. 


\title{
METHOD TO EVALUATE THE EFFECTS OF SUGARCANE STALKS COLONIZATION BY Clavibacter xyli subsp. xyli ON THE XYLEM FUNCTIONALITY
}

\author{
Author: Éder Antônio Giglioti \\ Adviser: Prof. Dr. Hasime Tokeshi
}

\section{SUMMARY}

Ratoon stunting disease (RSD) diagnosis by the staining by transpiration method (MCVX) and tissue blot immunoassay (TBIA) were carried out to study the colonization of sugarcane stalks by Clavibacter xyli subsp. xyli and its effects on water uptake through the xylem vessels of distinct genotypes.

MCVX stained the functional vascular bundles of the stalks but not the non-functional ones (NFVB), while TBIA stained the colonized vascular bundles (CVB). MCVX/TBIA jointed method consists in an interesting model for measuring physiological changes induced in the host by xylem inhabitant bacteria. Either TBIA or MCVX determined that colonized vascular bundles were most frequent in the inner tissues of sugarcane internodes, decreasing progressively as the tissues approximated the epidermis. At Canal Point, Florida, a good correlation between NFVB and CVB was obtained in a group of nine moderately resistant genotypes ( $r=0.987)$. In a second trial, using 19 genotypes that had a wider range of RSD reaction, the correlation between the two methods was just $r=0.40$. The main reason for the lower correlation was that some genotypes had a lower percentage of NFVB despite having a high percentage of CVB. In these genotypes, although the pathogen was present in the xylem, water uptake was not completely prevented.

A third experiment was conducted at Houma, Louisiana, to verify if the results from the second experiment could indicate tolerance to RSD. The correlation 
between \%CVB and \%NFVB was $r=0.68$, but none of them was correlated with yield damage (reduced cane yield) due to different levels of RSD tolerance. Functional xylem vessels despite being colonized by $C$. $x$. subsp. $x y l i$ was not sufficient to explain the tolerance observed in different genotypes. Other factors than mere water uptake prevention might be determining yield damage. In the other hand, innate processes of the plant which regulate the transpiration rate (water loss) and sensibility to water and nutrient transport prevention might be acting as mechanisms of tolerance to RSD.

The high correlation between \%CVB and \%NFVB in moderately resistant genotypes makes the TBIA and MCVX techniques suitable for screening sugarcane genotypes for resistance to RSD in the early stages of selection. MCVX appears to be an alternative method for development of resistant genotypes in developing countries, where labor is less costly and equipment as well as reagents required for TBIA are not easily obtained. However, in case of intermediate genotypes are not discarded earlier in the breeding program, yield data trials comparing production of healthy and diseased plots are recommended to determine levels of tolerance.

The knowledge of the resistance and tolerance level of each genotype before its release is essential for advising the use of complementary phytossanitary measures to reduce seed inoculum (Xo) and disease increasing in each stubble (r), only for genotypes where an epidemic potential had been observed. 


\section{INTRODUÇÃO}

A exploração da cultura canavieira em solos brasileiros é de grande importância socioeconômica, quer seja pela grande arrecadação financeira ou pela geração de empregos para grande parte da população. Como enfatiza Gheller (1995), nestas duas décadas finais do século XX, o setor sucroalcooleiro assumiu importância econômica e estratégica superior àquela que já apresentou por ocasião do Brasil colônia. A participação de seus produtos e subprodutos na economia nacional, notadamente o açúcar tradicional e o álcool como integrante definitivo da matriz energética nacional, ao lado da crescente alcoolquímica, vêm acompanhadas de abertura de novas frentes de desenvolvimento tecnológico para todos os elos da cadeia dessa agroindústria.

No setor agrícola, os fatores de produção da cultura devem estar bem ajustados para fornecer matéria prima em quantidade e qualidade para suprir as necessidades do parque industrial. Neste particular, área superior a 4 milhões de hectares é manejada anualmente, fato que classifica o Brasil como maior produtor mundial de cana-de-açúcar. Portanto, grande empenho deve ser carreado para o controle de fatores adversos que afetam negativamente o bom desempenho das lavouras, dentre os quais a ocorrência de doenças.

No Brasil, os primeiros danos na produtividade agrícola decorrentes de doenças foram observados há mais de 130 anos (Almeida, 1994). Após a detecção da gomose na Bahia, em 1863, a cana Caiana teve que ser substituída em virtude da severidade atingida pela doença naquele cultivar. A partir de então, a substituição de genótipos ocorreu e ainda ocorre de tempos em tempos, devido ao aparecimento de novas doenças como o Mosaico, o Carvão, o Raquitismo-da-soqueira e a Ferrugem nos anos 1924, 1946, 1956, 1986, respectivamente.

O Raquitismo-da-soqueira, causado pela bactéria corineforme Clavibacter xyli subsp. xyli (Davis et al., 1984), é considerado a doença mais importante da cana-de-açúcar, causando danos às principais regiões do mundo onde a agroindústria 
sucroalcooleira está presente (Gillaspie Jr. \& Davis, 1992; Davis et al, 1994). Somente no Estado da Flórida (EUA), Dean \& Davis (1989) estimaram perdas da ordem de 36,8 milhões de dólares, o que equivale a U\$ 206 por hectare (5 a 15\% da produção). Estas cifras podem atingir valores muito superiores no Brasil, onde acima de quatro milhões de hectares são cultivados com cana-de-açúcar, dos quais $90 \%$ apresentavam-se infectados pela bactéria do RS na década de 80 (Sanguino, 1987). Esta ocorrência generalizada se deve à ausência de genótipos imunes, à sobrevivência de algumas bactérias após o tratamento térmico, que não é de total eficiência na inativação de $C$. $x$. subsp. xyli, à alta infectividade do caldo contaminado e à não utilização da descontaminação de ferramentas por ocasião do plantio e colheita (Gillaspie Jr. \& Teakle, 1989).

Apesar desta situação alarmante, a ausência de sintomas característicos e falta de métodos de diagnose precisos e rápidos têm dificultado o melhor entendimento

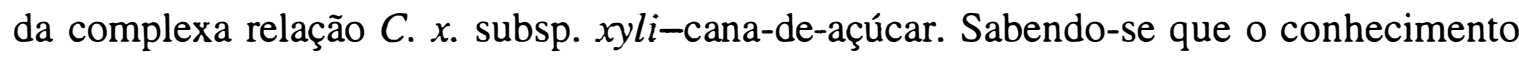
dos eventos que caracterizam o ciclo das relações patógeno-hospedeiro (sobrevivência, disseminação, infecção, colonização e reprodução do patógeno) é de capital importância para definir a melhor estratégia de controle (Zadocks \& Schein, 1979), vários pesquisadores dedicaram-se nos últimos anos na busca de métodos rápidos e precisos para quantificar a severidade do RS em colmos de cana-de-açúcar e, conseqüentemente, identificar os possíveis pontos críticos para o desenvolvimento da doença sobre cada genótipo em particular. Embora antes mesmo do conhecimento do agente causal do RS, a sobrevivência (Benda, 1975; Matsuoka, 1972; Welhburg, 1956) e disseminação (Hughes \& Steindl, 1955; Steib et al., 1957; Welhburg, 1956) do patógeno já fossem estudadas, somente após o desenvolvimento das técnicas de observação de células de $C$. $x$. subsp. xyli em microscópio de contraste de fase (Gillaspie Jr. et al., 1973) e de técnicas serológicas (Harrison \& Davis, 1990), esses dois eventos (Damann Jr., 1992; Damann Jr. \& Hollier, 1991; Taylor et al., 1988), mais a infecção (Harrison \& Davis, 1986) e colonização (Harrison \& Davis, 1988) começaram a ser melhor dimensionados em diferentes genótipos. 
"Tissue blot enzyme immunoassay" (TBIA), um método de diagnóstico sorológico, permitiu a avaliação da severidade do RS com base na quantificação do número de feixes vasculares colonizados por $C$. $x$. subsp. xyli (VC) em secções transversais de colmos de cana-de-açúcar (Harrison \& Davis, 1988). Assumindo que o número de VC apresenta boa correlação com danos na produção de cana-de-açúcar (Davis et al., 1994; Harrison \& Davis, 1988), TBIA tem sido sugerido como um método de diagnose para estimar a incidência (porcentagem de colmos afetados) e severidade (número médio de feixes vasculares colonizados) do RS, visando a identificação e seleção de genótipos resistentes. Porém, TBIA não pode ser aplicado no campo e requer equipamentos e reagentes muitas vezes aquém da realidade financeira de muitos países, principalmente daqueles ainda em desenvolvimento, o que tem sido um empecilho para sua ampla utilização. Por este motivo, foi desenvolvido um método baseado na utilização do fluxo transpiratório da planta como bomba natural de suç̧ão para coloração dos vasos do xilema (MCVX), o que permite estimar a severidade do RS pela porcentagem de vasos não funcionais (Chagas, 1986; Chagas, 1996; Chagas \& Tokeshi, 1994ab; Iamauti, 1990; Iamauti \& Tokeshi, 1994). O uso do MCVX tem sido sugerido por assumir existência de correlação entre diferença no fluxo de água através de internódios afetados e porcentagem de vasos funcionais e danos em produção (Cruz, 1983; Douglas, 1981; Valarini, 1978).

Embora tanto MCVX como TBIA estimem a severidade do RS em colmos de cana-de-açúcar, o primeiro é um método que avalia os efeitos do RS pela porcentagem de vasos não funcionais, não fornecendo nenhuma informação a respeito da colonização dos vasos por $C$. $x$. subsp. xyli. Esta informação, no entanto, é dada pelo TBIA, que detecta sorologicamente o número de vasos colonizados pela bactéria. Portanto, pelo menos no ponto de vista da fisiologia do parasitismo, os métodos parecem complementares, pois juntos poderiam avaliar a presença e os efeitos do patógeno no interior do hospedeiro. Então, o presente trabalho se propôs a conciliar TBIA e MCVX para estudar a colonização de colmos de cana-de-açúcar por $C$. $x$. subsp. xyli e os respectivos efeitos na funcionalidade dos vasos do xilema de genótipos diferindo em 
suscetibilidade e tolerância ao RS, objetivando determinar: (i) o padrão de colonização de $C$. $x$. subsp. xyli em secções transversais de colmos de cana-de-açúcar, (ii) a relação entre o número de vasos colonizados e o de vasos não funcionais, (iii) a confiabilidade do MCVX para identificar genótipos resistentes ao RS, (iv) a aplicabilidade do MCVX e TBLA para identificação de genótipos tolerantes, em ensaios de avaliação de danos causados pelo RS, (v) a relação entre aspectos fisiológicos do entupimento dos vasos do xilema e tolerância de genótipos de cana-de-açúcar ao RS e, conseqüentemente, (vi) as implicações do conhecimento do ciclo das relações $C$. $x$. subsp. $x y l i$-cana-de-açúcar no controle integrado do RS. 


\section{REVISÃO DE LITERATURA}

\subsection{História e importância do Raquistismo-da-soqueira (RS)}

No verão de 1944-45, na Austrália, pela primeira vez se tinha notícia da ocorrência do Raquitismo-da-soqueira (RS) que, na época, foi chamado de "Q 28 trouble" ou "Q 28 disease". Após uma primavera bastante seca, alguns canaviais do então novo e promissor cultivar Q 28 apresentavam soqueiras subdesenvolvidas. Embora nada tivesse sido observado em cana-planta, a mesma anomalia ocorria nas socas dos viveiros que deram origem a esses canaviais, sugerindo que já em 1942 a anomalia incidia sobre o viveiro da Q 28 e, a partir daí, tenha sido disseminado para canaviais comerciais (Steindl, 1961). Em 1949, a natureza infecciosa do RS foi comprovada, através de estudos de reprodução de sintomas a partir de inoculações artificiais com caldo extraído de colmos afetados (Steindl, 1949). Estes estudos determinaram também que o principal agente transmissor da doença era o próprio homem com suas ferramentas de trabalho, como as máquinas de plantio e facões utilizados na colheita. Posteriormente, o RS foi descrito a maioria dos produtores de cana-de-açúcar do mundo, sendo esta ampla distribuição atribuída à troca de germoplasma contaminado, em virtude da ausência de sintomas característicos da doença (Gillaspie Jr. \& Teakle, 1989), inclusive para o Brasil (Veiga, 1956).

Inicialmente se acreditava que o RS fosse causado por um vírus, principalmente pelo fato de que não se conseguia cultivar o patógeno em cultura axênica, sendo filtrado e transmitido mecanicamente (Steindl, 1961). Isto estimulou a realização de estudos para caracterizar um possível vírus associado à doença (Gillaspie Jr. et al., 1966; Matsuoka, 1972). No entanto, mais tarde, três diferentes grupos de pesquisadores, trabalhando independentemente, reportaram a descoberta de uma bactéria habitante do xilema como agente causal do RS (Gillaspie Jr. et al., 1973; Maramoroch et al., 1973; Teakle et al., 1973). Com esta informação, Liu et al. (1974) e Tokeshi et al. (1974) 
tentaram identificar e classificar a bactéria do RS como Xanthomonas vasculorum (causador da gomose) e Xanthomonas albilineans (agente causal da escaldadura das folhas), respectivamente. Porém, somente em meados da década seguinte, o Dr. Michael J. Davis, na época trabalhando como bacteriologista no "Ft. Lauderdale Research and Education Center" da Universidade da Flórida, comandava uma equipe que foi capaz de isolar a bactéria em cultura axênica e confirmar sua patogenicidade através dos postulados de Koch (Davis et al.,1984). Classificaram-na como Clavibacter xyli subsp. $x y l i$, ao mesmo tempo em que efetuaram uma reclassificação de todas as bactérias pertencentes ao gênero Corynebacterium.

Os efeitos do RS na produtividade de cana-de-açúcar têm sido amplamente estudados. De acordo com Hughes (1974), os prejuízos causados pelo RS são classificados em indiretos (emergência e perfilhamento deficientes, cultivos extras nas canas-planta e soca, maior custo de colheita devido à menor produtividade agrícola $\mathrm{e}$ à presença de plantas daninhas e menor longevidade das lavouras) e diretos (menor produtividade dos canaviais, menor número de cortes e custos advindos do emprego de medidas de controle da doença). O RS afeta tanto cana-planta como soca, embora soqueiras são, geralmente, mais severamente prejudicadas. Esta observação foi feita há muito tempo, quando a cana-planta do genótipo Q 28 apresentava danos entre 17 a 37\%, enquanto que nas soqueiras esse valor ultrapassou os $60 \%$. A redução em produção é devido à presença de colmos mais finos e pequenos e não à diminuição do número de colmos, embora durante períodos secos o "stand" é também afetado, podendo ser observadas falhas nas linhas da cultura (Steindl, 1961).

Considerando que genótipos altamente suscetíveis não são mais cultivados nos dias de hoje, os danos causados pelo RS variam freqüentemente de $5 \%$ a $30 \%$, dependendo do genótipo de cana-de-açúcar (nível de resistência e tolerância), da quantidade de água disponível no solo (regime de chuvas e capacidade de retenção de água do solo), da presença de outras doenças (efeitos sinergísticos e aditivos) e do ciclo da cultura, como duração e época de cultivo (Dean \& Davis, 1989; Gillaspie Jr. \& Davis, 1992). Efeito sinergístico levando a uma redução de produtividade acentuada foi 
observada quando a cultura estava infectada com o vírus do mosaico, segundo Koike (1974; 1982) e Steib $(1972 ; 1974)$. Solos infestados com nematóide também agravam o problema, tendo uma interação aditiva com RS (Matsuoka \& Aguillera, 1981).

A exemplo de outros países, a canavicultura brasileira é alvo dos danos causados pelo RS. A estimativa de queda de produtividade atingiu valores da ordem de $16 \%$ a $37 \%$ para os genótipos CB41-76, CB49-260 e IAC52-326 (Matsuoka, 1976; 1984). Os danos podem ter sido ainda maiores ao ser considerado que, por ocasião da década de $80,90 \%$ dos canaviais brasileiros estavam infectados pela bactéria do RS, em diferentes intensidades, e que os danos podiam chegar até 60\% (Sanguino, 1987). Nesta década de 90, o problema ainda persiste, pois muitas unidades produtoras desativaram o sistema de tratamento térmico para a produção de mudas sadias que era largamente utilizado na década de 80 (Ruas et al., 1987), alegando necessidade de redução de custos de produção. Esta decisão administrativa pode ter um efeito ilusório, pois o potencial de danos é de $22,8 \%$ e $9,5 \%$, respectivamente, quando a doença incide em $95 \%$ dos colmos dos genótipos SP70-1284 e 69\% dos colmos da SP70-1 143 (Sanguino, 1993), genótipos que ainda ocupam expressivas áreas de cultivo no estado de São Paulo (Gheller, 1996). Por outro lado, aquela decisão seria aceitável para o cultivar mais plantado no Brasil, RB72454, que, segundo Chagas (1996), apresenta tendência a tolerar os efeitos do RS.

\subsection{Etiologia}

Desde 1949, após a confirmação da natureza infecciosa do RS (Steindl, 1949), a identificação e classificação de seu agente causal percorreu um árduo e longo caminho. A dificuldade de isolamento do microrganismo, só pôde ser entendida 35 anos mais tarde, quando a natureza fastidiosa da bactéria associada ao RS foi comprovada (Davis et al., 1984). Com esta publicação, os pesquisadores caracterizaram um novo gênero contendo algumas bactérias fitopatogênicas corineformes, incluindo Clavibacter $x y l i$ subsp. xyli, agente causal do RS. 
C. $x$. subsp. xyli é gram-positiva, corineforme, não móvel e aeróbica obrigatória. As células bacterianas são bastonetes pleomórficos de 0,25-0,5 $\mu \mathrm{m}$ por 1-4 $\mu \mathrm{m}$, com forma reta ou levemente curva e ocasionalmente inchada na ponta ou no meio (Teakle et al., 1979). As colônias apresentam aspecto não pigmentado e circular, com um diâmetro variando de 0,1 a 0,3 mm, quando crescidas em meio SC (Davis et al., 1984). A exemplo de outros membros do gênero Clavibacter, o patógeno do RS não forma esporos e é caracterizado pela presença do ácido 2,4 diaminobutírico em sua parede celular, ausência de ácidos micolíticos e predominância de metaquinonas com 9 ou 10 cadeias de carbono (Davis et al., 1984; Davis, 1986; Young et al., 1992).

O conteúdo de $\mathrm{G}+\mathrm{C}$ de $C$. $x$. subsp. xyli é $66 \mathrm{~mol} \%$. O extrato de ácidos graxos totais possui de 17 a 24,5 a 14 e 62 a $72 \%$ dos ácidos 15:0 anteiso, 16:0 iso e 17:0 anteiso, respectivamente (Gillaspie Jr. \& Davis, 1992). Variação em patogenicidade e virulência entre isolados de $C$. $x$. subsp. $x y l i$ não têm sido identificados, sendo os isolados de diferentes regiões do mundo muito similares quando comparados quanto à morfologia, sorologia e bioquímica (Davis et al., 1980; Davis et al., 1984).

\subsection{Sintomas e fatores que afetam sua expressão}

Como o próprio nome diz, colmos atrofiados e plantas de cana-de-açúcar subdesenvolvidas no campo consistem a forma de manifestação externa do RS. Quando infectados, genótipos suscetíveis têm seu crescimento retardado e, em condições extremas. apresenta um aspecto de murcha, necrose nas pontas e bordas das folhas e subsequiente morte de toda a touceira (Steindl, 1961). Como resultado do crescimento lento, a competição com plantas daninhas se agrava, acentuando os sintomas descritos acima (Gillaspie Jr. \& Davis, 1992).

Os sintomas externos do RS podem ser tanto aumentados como mascarados pela disponibilidade de água para a planta. Por isso, alguns genótipos, sob condições de umidade apropriada, podem suportar alta densidade populacional da bactéria, sem mostrar qualquer sintoma visível. Até mesmo as touceiras de um canavial 
totalmente infectado podem apresentar graus de subdesenvolvimento variáveis, indicando desuniformidade de manifestação dos efeitos da doença (aspecto de "altos e baixos") e, conseqüentemente, dá suporte à natureza não confiável dos sintomas externos como ferramenta de diagnose (Sivanesan \& Waller, 1986; Gillaspie Jr. \& Teakle, 1989; Gillaspie Jr. \& Davis, 1992). Complicando ainda mais, a presença e a intensidade dos sintomas causados pelo RS são determinadas pelo genótipo e idade da cultura, além de condições climáticas. Assim, alguns genótipos sofrem severamente, enquanto outros se mostram, comparativamente, não afetados (Steindl, 1961). Quando presentes, os sintomas podem estar associados com outros fatores, como ano agrícola com pluviosidade desfavorável e/ou práticas culturais inadequadas, que determinariam à planta uma condição de estresse (presença de plantas daninhas, compactação do solo, acúmulo ou falta de adubos, corretivos e herbicidas, ocorrência de outras doenças, etc.).

Alternativamente aos sintomas externos, dois tipos de descoloração interna dos tecidos de colmos doentes podem ser encontrados. Colmos mais maduros apresentam pontuações ou vírgulas avermelhadas como conseqüência da deposição de gomas e/ou tiloses nos feixes vasculares do xilema, enquanto que uma coloração rosa generalizada é observada na região nodal ou abaixo do meristema apical de canas bem jovens (Hughes \& Steindl, 1955; Steindl, 1961). Embora essa descrição tenha sido importante para que o RS passasse a ser descrito em diferentes países do mundo (Gillaspie Jr. \& Teakle, 1989), este sintoma não é específico da doença, sendo também decorrente de danos mecânicos, ataque de pragas e patógenos como Fusarium moniliforme, Colletotrichum falcatum, Xanthomonas albilineans, Xanthomonas camperstris pv. vasculorum, Erwinia herbicola e agentes de Estrias cloróticas (Ricaud, 1974; Tokeshi, 1980); além de alguns clones nunca desenvolverem este sintoma. Além disso, a descoloração interna é difícil de ser observada após a secagem e escurecimento normais dos tecidos (Gillaspie Jr. \& Davis, 1992).

Diante do exposto, o RS inclui-se entre as doenças de difícil diagnose através de sintomas, fato que não passou desapercebido aos olhos aguçados de fitopatologistas e/ou melhoristas. Atentos ao problema, esses pesquisadores driblaram 
muitos obstáculos com o objetivo de entregar ao setor canavieiro um método rápido, eficiente e barato para diagnosticar a doença.

\subsection{Métodos de diagnose do RS}

A diagnose baseada em sintomas internos ou externos tem sido muito variável dependendo do genótipo em estudo, condições ambientais e presença de outras doenças (Ricaud, 1974). Por este motivo, várias técnicas foram desenvolvidas para a diagnose e, em alguns casos, para quantificar $C$. $x$. subsp. xyli em colmos de cana-deaçúcar. Dentre elas, plantas indicadoras com uma resposta conhecida ao RS foram inicialmente propostas (Matsuoka, 1972; Ricaud, 1974; Steindl \& Teakle, 1974). Contudo, esta técnica demanda muito tempo, sendo seu uso também limitado pela inespecificidade dos sintomas (Betti et al., 1980).

A diagnose do RS através do isolamento da bactéria causal em cultura axênica (Davis et al., 1980; Gillaspie Jr. and Teakle, 1988) é dificultada pelo lento crescimento de $C$. $x$. subsp. xyli, pela complexidade do meio de cultura exigido e pela 3contaminação com outros microorganismos (Harrison \& Davis, 1990).

Após a associação do RS com uma bactéria (Gillaspie Jr. et al., 1973; Maramorosch et al., 1973; Teakle et al., 1973), diagnose confiável começou a ser implementada com a técnica de observação de células do patógeno em microscópio de contraste de fase (Gillaspie Jr. et al., 1973) e eletrônico (Kao \& Damann Jr., 1980; Teakle et al., 1975b; Teakle et al., 1979; Worley \& Gillaspie Jr., 1975). Estas técnicas, contudo, levam à diagnose incorreta (falso negativo) quando a população bacteriana é baixa (Davis \& Dean, 1984). Por outro lado o uso do microscópio de epifluorescência para detectar feixes vasculares colonizados por $C$. $x$. subsp. xyli (Damann Jr., 1988) é também passível de erro pelo risco de detectar falsos positivos. A técnica se baseia na fluorescência das paredes secundárias do metaxilema infectado, quando este é tratado com Tris $0,1 \mathrm{M}$ (tris [hydroxymethyl] aminomethane), $\mathrm{pH} 10$. Portanto, o método pode 
detectar um fenômeno associado com condições de estresse por outras causas além de RS (Gillaspie Jr. \& Davis, 1992).

Métodos sorológicos têm sido usados para implementar a especificidade e sensibilidade da diagnose do RS (Gillaspie Jr., 1978). Gillaspie Jr. \& Harris (1979) examinaram a possibilidade de usar a técnica "enzyme-linked immunosorbent assay (ELISA)"; contudo, a reação cruzada com outras bactérias limitou seu uso. As técnicas "Fluorescent-antibody staining" e "fluorescent-antibody-direct-count (FADC)" em filtros ou lâminas foram desenvolvidas para estimar a população da bactéria em cultura pura ou em amostras de suco de cana-de-açúcar (Harris \& Gillaspie Jr., 1978; Davis, 1985). A sensibilidade estimada da FADC foi de $10^{4}$ células/ml. Portanto, 10 vezes mais sensitiva que a simples contagem em microscópio de contraste de fase (Davis, 1985). Na tentativa de tornar a sorologia mais prática, foram desenvolvidos os métodos "dot-blot enzyme immunoassay" (Harrison \& Davis, 1980) e "tissue blot enzyme immunoassay - TBIA" (Harrison \& Davis, 1988), para determinar a presença da bactéria em extratos da planta e o número de feixes vasculares colonizados por $C$. $x$. subsp. $x y l i$ em secções transversais de colmos de cana-de-açúcar, respectivamente. Embora ambos os métodos tenham sido menos sensitivos que FADC, sendo o limite de deteç̧ão da ordem de $10^{6}$ células $/ \mathrm{ml}$ (Harrison \& Davis, 1990), o TBIA é capaz de detectar pelo menos 7,07 x 10 células $/ \mathrm{mm}^{2}$ de superfície de membrana de nitrocelulose, ou seja, para detectar a deposição de células na área equivalente à área do tamanho da seç̧ão transversal do metaxilema (aproximadamente a $0,006 \mathrm{~mm}^{2}$ ), apenas 46 células devem estar presentes na membrana. Depósitos coloridos de dimensões similares à de um metaxilema individualizado foram observadas em membranas processadas por Harrison \& Davis (1988). Esta sensibilidade é, pelo menos, igual à obtida pela diagnose da presença de $C$. $x$. subsp. $x y l i$ em extratos de xilema através de "polymerase chain reaction - PCR" (Astua-Monge, 1995).

TBIA consiste basicamente em amostrar cilindros de tecido da região central dos internódios de colmos de cana-de-açúcar. Este tecido é centrifugado de maneira a coletar o suco de cada feixe vascular em membrana de nitrocelulose. Após 
processamento sorológico, feixes vasculares colonizados por $C$. $x$. subsp. xyyli são identificados na membrana pela coloração azulada, quando observados através de microscópio estereoscópico (Harrison \& Davis, 1988). Esta característica, associada à capacidade de processar amostras múltiplas e praticidade da técnica, faz com que TBIA seja uma excelente ferramenta para estimar incidência (\% de colmos infectados) e severidade (número médio de feixes vasculares colonizados) do RS em amostras de colmos de cana-de-açúcar (Comstock et al, 1996ab; Davis et al., 1994; Harrison \& Davis, 1988; Miller et al., 1995).

Alternativamente, como a maioria dos métodos de diagnose não apresentam praticidade e aplicabilidade no campo e são caros, o método MCVX (staining by transpiration method) foi desenvolvido no Brasil (Chagas, 1986, Chagas \& Tokeshi, 1994a). Usando o mecanismo de transpiração da planta como uma bomba de sucção natural, MCVX colore com uma solução vermelha à base de safranina $\mathrm{O}$ os vasos do xilema funcionais, mas não os entupidos pela ação de $C$. $x$. subsp. xyli. Contudo, apesar de sua eficiência comparada com o método de diagnose pela observação da bactéria em microscópio de contraste de fase (Iamauti \& Tokeshi, 1994), uma questão permanece: o entupimento está relacionado com a presença da bactéria nos vasos do xilema? Isso pode ter sido uma das causas da não utilização do MCVX em larga escala. Portanto, a aplicação deste método conciliado com o TBIA em muito contribuiria para responder tal questão.

\subsection{Menor eficiência no transporte de água e sais minerais: alteração} fisiológica no hospedeiro induzida por $C$. $x$. subsp. $x y l i$

Muito antes de se conhecer a verdadeira causa do RS, foi observado que plantas inoculadas com caldo bruto extraído de colmos com sintomas da doença sofriam mais os efeitos do déficit hídrico, nas horas mais quentes do dia (Hughes \& Steindl, 1955). Estimulado em acreditar que a doença afetava o transporte de água da planta, Steindl (1961) começou a investigar a razão para tal fato, através de análises 
microscópicas de cortes histológicos de colmos de plantas afetadas. Nestes cortes, observou-se a presença de substâncias gomosas em muitos feixes vasculares que apresentavam-se obstruídos e com uma coloração avermelhada. Baseado nestes fatos, o autor sugeriu a aceitação de sua hipótese inicial: "O RS afeta o transporte de água e sais minerais através da obstrução dos feixes vasculares do xilema". Porém, a menor condutividade hidráulica em colmos de cana-de-açúcar com RS só foi demostrada no final da década de 70 (Valarini \& Tokeshi, 1981), sendo os resultados obtidos por estes autores confirmados em trabalhos posteriores que exploraram a mesma linha de pesquisa (Chagas, 1986; Chagas, 1996; Chagas \& Tokeshi, 1994ab; Cruz, 1983; Davis \& Harrison, 1987; Douglas, 1981; Iamauti \& Tokeshi, 1994).

Embora os processos envolvidos no entupimento do xilema não estejam claramente elucidados, a ação de $C$. $x$. subsp. xyli parece ser de natureza tanto física como bioquímica. A parede secundária dos vasos do xilema ficam recobertas pelas células deste patógeno, entupindo os poros laterais e, consequentemente, impedindo a comunicação entre vasos. A partir da parede secundária, a bactéria cresce em direção ao lúmen, agindo como barreira física ao transporte de água através do xilema (Kao \& Damann Jr., 1980). Estando esta bactéria freqüentemente associada a uma matriz amorfa (Kamiunten \& Wakimoto, 1976; Kao \& Damann Jr., 1980; Weaver et al.,1977; Worley \& Gillaspie Jr., 1975), também o entupimento por reações bioquímicas do patógeno e/ou hospedeiro podem estar envolvidas. Embora experimentos envolvendo colorações indicaram a natureza pectinosa da matriz, tratamentos com pectinase não degradaram este material. Um material semelhante a gel, presumivelmente originário da parede dos vasos, envolve as células bacterianas e cobre a parede secundária dos vasos, entupindo os poros laterais do xilema. Além disso, a presença de gomas no lúmem dos vasos pode também contribuir para a redução no fluxo de água em colmos infectados (Steindl, 1961; Weaver et al., 1977).

Apesar de ser sugerida a hipótese de que $C$. $x$. subsp. xyli usa atividade enzimática para transpassar barreiras naturais dentro do xilema (Gillaspie Jr. \& Davis 1992) e criar buracos na membrana entre vasos, permitindo que a bactéria se mova 
através da planta (Weaver et al., 1977; Worley \& Gillaspie Jr., 1975), a integridade física das células do xilema é mantida, mesmo em estágios avançados de colonização (Kao \& Damman, 1980). A maioria dos patógenos vasculares rapidamente preenchem o lúmem dos vasos infectados e rompem a parede celular pela pressão bacteriana interna, dissolução da parede ou pelo movimento dentro de células adjacentes ou espaços intercelulares (Nelson \& Dickey, 1970). Isso geralmente resulta em necrose dos tecidos vasculares e murcha, o que não é observado em cana-de-açúcar infectada por $C$. $x$. subsp. xyli.

A formação de géis é considerada ser um mecanismo de defesa da planta para localizar o patógeno no sistema vascular, sendo esta substância originada, provavelmente, a partir de constituintes da lamela média (VanderMolen et al., 1977). Contudo, a presença de géis não foi um mecanismo eficiente para defender o cultivar L62-96 contra a invasão da bactéria do RS (Kao \& Damman, 1980). Estes autores examinaram muitas seç̧ões de colmos infectados, concluindo que a distribuição de $C$. $x$. subsp. xyli não tinha sido retardada pela presença de géis. O entupimento físico do xilema pela célula bacteriana, gomas e géis foi considerado a principal causa das perdas causadas pelo RS. Isto sugere que os géis desempenham um papel destrutivo e não defensivo no desenvolvimento dessa doença. Porém, como a taxa de transpiração de plantas com RS não foi significativamente reduzida (Kao \& Damman, 1980), parece que outros fatores, além do mero entupimento dos vasos, são responsáveis pelas perdas. Portanto, a relação entre colonização, entupimento dos vasos e perdas permanece indefinida, sugerindo que estudos nesta área em muito contribuiria para melhor entender a complexa interação $C$. $x$. subsp. xyli - cana-de-açúcar. Neste particular, a aplicação conjunta dos métodos TBIA e MCVX, avaliando a colonização e respectivos efeitos na funcionalidade dos vasos, respectivamente, é um estudo necessário. 


\subsection{Ciclo das relações Clavibacter xyli subsp. xyli - cana-de-açúcar}

De acordo com Amorim (1995), o desenvolvimento de doenças infecciosas é caracterizado pela ocorrência de uma série de eventos sucessivos e ordenados, incluindo a sobrevivência, disseminação, infecção, colonização e reprodução do patógeno. Trata-se de um processo cíclico designado ciclo das relações patógeno hospedeiro. O conhecimento deste processo é necessário para definir a melhor estratégia visando diminuir as perdas causadas por agentes fitopatogênicos. Isto porque, os princípios gerais de controle de doenças foram enunciados como passos sequenciais lógicos, levando em conta o ciclo das relações patógeno-hospedeiro sob os efeitos do ambiente (Kimati \& Bergamin Fo., 1995). Assim, a exclusão interfere na fase de disseminação; a erradicação, na sobrevivência; a proteção, na subfase chegada do inóculo e penetração; a imunização na infecção e colonização; a terapia, na fase pósinfecção; a regulação, na mudança do ambiente; e a evasão na escolha de época e local de plantio. Neste particular, o entendimento do ciclo das relações $C$. $x$. subsp. $x y l i$-canade-açúcar pode trazer grandes benefícios para um controle mais racional e econômico do RS.

\subsubsection{Sobrevivência}

Para que uma planta de cana-de-açúcar seja infectada por Clavibacter $x$. subsp. xyli é necessário que células do patógeno sejam mantidas ativas (sobrevivência) entre os diferentes ciclos da cultura (renovação do canavial, cana-planta e socas) em algum lugar (fonte de inóculo) e, posteriormente, sejam transportadas para dentro do tecido suscetível dos colmos (transmissão).

Não existem relatos da sobrevivência de $C . x$. subsp. xyli em sementes verdadeiras de cana-de-açúcar ou em insetos vetores. Embora o solo possa atuar como fonte de inóculo (Autrey et al., 1991; Bailey \& Tough, 1991), na prática, a manutenção deste patógeno fica na dependência de plantas hospedeiras. Além da cana-de-açúcar, 
milho, sorgo e várias outras espécies de gramíneas comumente encontradas em canaviais podem permitir o crescimento da bactéria após inoculação (Gillaspie Jr. \& Teakle, 1989; Matsuoka, 1972). Em Cuba a doença foi transmitida para sorgo, resultando em raquitismo (Wehlburg, 1956). Na Louisiana, o híbrido sorghum-sudangrass mostrou murcha característica (Benda, 1975).

Embora muitas gramíneas tenham sido artificialmente inoculadas com a bactéria do RS, nenhuma tem sido encontrada naturalmente infectada, dentro ou nas proximidades de canaviais, descartando a hipótese de que hospedeiros alternativos naturais poderiam constituir uma estratégia de sobrevivência de $C$. $x$. subsp. xyli. Este patógeno conta sempre com a presença de seu hospedeiro natural, pois a exploração econômica da cana-de-açúcar é caracterizada pela monocultura (continuidade espacial) e sobreposição de cultivos (continuidade sequencial). Sendo assim, a bactéria sobrevive durante todo o ciclo da cultura colonizando sistematicamente os vasos do xilema e do floema dos colmos de cana-de-açúcar. Durante a entressafra, a sobrevivência é garantida pela presença de bactérias na coroa das soqueiras que permanecem no solo após o corte da cana. Quando um canavial é reformado, mudas infectadas suprem o inóculo necessário para o início da doença na nova cana-planta. Caso mudas sadias sejam utilizadas no plantio, a sobreposição de cultivos, ou seja, a presença de canaviais infectados nas proximidades se encarrega de assegurar a sobrevivência de $C$. $x$. subsp. $x y l i$ para sua posterior introdução na área reformada, através de equipamentos de plantio e colheita contaminados.

\subsubsection{Disseminação}

Dentro das relações patógeno-hospedeiro, a disseminação é o processo responsável pelo incremento da doença no espaço e no tempo, englobando a remoção do patógeno de uma planta infectada, o seu transporte e a sua deposição no hospedeiro (Amorim, 1995). Embora tenha sido mencionado que alguns animais tais como ratos poderiam transmitir $C$. $x$. subsp. xyli pela alimentação em planta doente e sadia, 
respectivamente (Welhburg, 1956), o Homem, através de seus instrumentos de corte, constitui-se no principal agente disseminador desta bactéria. As principais maneiras de disseminação são através de facas, equipamentos de plantio, cultivo e colheita.

A introdução do RS num canavial pode ocorrer através do plantio de mudas contaminadas ou pelo uso de equipamentos de plantio e colheita que transportam a bactéria $C$. $x$. subsp. $x y l i$ de uma área previamente infectada para introduzi-la dentro do xilema dos colmos de uma nova área (Gillaspie Jr. \& Teakle, 1989). A ausência de sintomas característicos e de métodos rápidos e eficientes para diagnosticar o RS fez com que a doença fosse levada para as principais regiões produtoras de cana-de-açúcar do mundo, através da troca de germoplasmas infectados. Porém, a implantação da lavoura com mudas sadias não é garantia de que a cultura permanecerá livre da doença durante todo seu ciclo. Apesar da disponibilidade de métodos de tratamento térmico para o controle do RS, o nível de doença em viveiros, na Louisiana, em 1986, foi estimado em 33\% (Damann Jr. \& Hollier, 1991). Isto ocorre devido à alta eficiência da transmissão mecânica a longa distância promovida pelos equipamentos de plantio, tratos culturais e colheita, carregando a bactéria ativa de campos infectados para lavouras recém implantadas com mudas tratadas termicamente.

Através do uso de mudas contaminadas, o aumento da quantidade de plantas infectadas dentro de um canavial é inicialmente proporcionado por instrumentos de corte durante o plantio. Neste caso, durante a picação das mudas no sulco de plantio, o inóculo originado no viveiro de mudas serve para infectar toletes anteriormente sadios. Este tipo de transmissão foi notada logo nas primeiras investigações com a Q. 28, em Queensland. Quando canas doentes foram colocadas espaçadamente entre várias canas sadias, durante a instalação de ensaios de produção, a máquina de plantio carregou a infecção para 60 plantas consecutivas (Hughes \& Steindl, 1955).

Após a introdução de $C$. $x$. subsp. xyli numa nova área, a doença evolui rapidamente para as soqueiras subsequentes, através da transmissão por equipamentos de corte (podões, lâminas de colheitadeiras, etc.), durante a colheita. Segundo Steib et al. (1957), na Louisiana da década de 50, ocorreu alta taxa de aumento de incidência de 
colmos infectados de cana-planta (incidência $=16 \%$ ) para cana-soca (incidência $=$ 47\%). Em média, analisando-se diversos genótipos, pode-se considerar um taxa de $10 \%$ de incremento anual na incidência de colmos infectados, durante cinco anos após o tratamento térmico (Damann Jr. \& Hollier, 1991). Porém, deve-se ter em mente que a transmissão do RS entre colmos da cana-planta para primeira soca e desta para a segunda soca é afetada pela suscetibilidade do cultivar e pela quantidade de inóculo na forma de plantas doentes (Comstock et al., 1996b; Damann Jr., 1992).

Dois principais fatores, ambos relacionados ao genótipo, provavelmente afetam a eficiência de disseminação do RS na colheita: a concentração de bactéria necessária para infectar 50\% das plantas inoculadas (ED50) e a quantidade de bactéria presente nos colmos (reservatório de inóculo). Estes parâmetros são determinados pela habilidade da bactéria infectar e colonizar os tecidos de colmos de cada genótipo de cana-de-açúcar.

A relação entre a população de $C$. $x$. subsp. xyli em plantas infectadas e a ED50 para a inoculação de um cultivar parece estar relacionada com a disseminação da doença. Neste particular, Damann Jr. (1992), especulando os efeitos da suscetibilidade de genótipos na disseminação por colheita mecânica, sugeriu que quando a população do patógeno é pequena, e um alto título (ED50) são necessários, pouca disseminação pode ser esperada, como ocorreu com o genótipo L60-25 (nenhuma disseminação foi encontrada). Quando a população do patógeno excede por várias vezes a ordem de magnitude da ED50 para inoculação, então significativa disseminação é esperada, como aconteceu com a L62-96. Sobre genótipos que se enquadram neste ultimo caso a disseminação pode ser tão eficiente, a ponto de a bactéria ser transmitida até 35 touceiras da fonte de inóculo (Taylor et al. 1988). Este parâmetro pode ser útil para estabelecer limites de tolerância de sanidade de mudas, projetando a evolução da doença para pelo menos 5 ciclos de cultura, no caso do Brasil. 


\subsubsection{Infecção, colonização e reprodução}

Para a maioria dos patógenos, o processo de infecção engloba os mecanismos de pré-penetração, penetração e estabelecimento das relações parasitárias (Amorim, 1995). No caso da interação $C$. x. subsp. xyli - cana-de-açúcar, pré-penetração é desconsiderada, pois, na prática, não existe evidências de que a bactéria permaneça na superfície do hospedeiro, antes da penetração. Esta é então conseguida passivamente via ferimentos por equipamentos de corte, através dos quais a bactéria é introduzida no interior do hospedeiro.

A densidade populacional de $C$. $x$. subsp. xyli necessária para a ocorrência de infecções é dependente do genótipo em questão. Tanto maior é a densidade requerida quanto mais resistente for o genótipo. Genótipos resistentes apresentaram valores de ED50 (concentração de bactéria necessária para infectar 50\% das plantas inoculadas) na ordem de $10^{8}$ células $/ \mathrm{ml}$, enquanto as suscetíveis em torno de $10^{4}$ células $/ \mathrm{ml}$. Após a infecção, marcada pelo estabelecimento das relações parasitárias, a bactéria do RS se distribui dentro dos tecidos do hospedeiro, colonizando diferentes órgãos da planta. Pesquisas a esse respeito começaram a tomar impulso após se conseguir associar uma bactéria com o RS (Gillaspie Jr. et al., 1973; Maramorosch et al., 1973; Teakle et al., 1973). Estudos in situ demostraram que a reprodução de $C$. $x$. subsp. $x y l i$ é limitada aos vasos, traqueídios, parênquima e lacunas do xilema (Kamiunten \& Wakimoto, 1976; Kao \& Damann Jr., 1980; Worley \& Gillaspie Jr., 1975; Weaver et al., 1977). Tanto raízes como folhas e colmos (Damann Jr. \& Hollier, 1991; Damann Jr., 1992; Gillaspie Jr. \& Davis, 1992) podem ser colonizados. No entanto, é muito importante ressaltar que a bactéria do RS nunca foi encontrada nas gemas e nos embriões de cana-de-açúcar (Gillaspie Jr. \& Davis, 1992).

Com relação às folhas, tem sido reportado que aquelas mais velhas, na parte inferior da planta, tem maior nível populacional que aquelas da parte superior (Teakle et al., 1975a). No entanto, folhas do cartucho, pontos de crescimento, lâmina foliar, nervuras centrais das folhas e bainhas tem menor concentração comparada com 
colmos (Bailey, 1977). Portanto, em termos epidemiológicos, o colmo é o ponto crítico para o desenvolvimento do RS, pois ele, ao abrigar a infecção, colonização e reprodução de $C$. $x$. subsp. $x y l i$, consiste na principal fonte de inóculo para a disseminação do patógeno. Nos colmos, foi encontrada maior concentração da bactéria na região nodal que nos internódios (Bailey, 1977). Além disso, maior densidade populacional foi observada em suco extraído dos internódios basais, ou seja, nos internódios mais maduros do colmo, sendo que esta densidade populacional aumentava à medida que a planta atingia a maturidade (Davis et al., 1988a). De maneira similar, o número de feixes vasculares colonizados pela bactéria do RS aumentava do ápice para a base dos colmos e à medida que estes ficavam mais velhos. Analisando-se a distribuição transversal de vasos infectados, a colonização do xilema foi maior nos tecidos centrais em relação aqueles próximos à epiderme (Harrison \& Davis, 1988).

Tanto a concentração da bactéria (Gillaspie Jr. et al., 1976; Iamauti, 1990) como a intensidade de colonização (Comstock et al., 1996ab; Davis et al., 1994; Harrison \& Davis, 1988; Miller et al., 1995) tende a ser maior em colmos de cana-deaçúcar de genótipos suscetíveis. No primeiro caso, a densidade populacional em genótipos suscetíveis foi na ordem de $10^{8}$ células $/ \mathrm{ml}$, enquanto que nos resistentes foi de $10^{6}$ células/ml. Com relação à colonização, acima de cinco vasos colonizados já é suficiente para classificar genótipos como suscetíveis (Comstock, 1997).

\subsection{Medidas de controle do RS}

O controle do RS é dificultado pela facilidade de disseminação mecânica (via ferimento) que ocorre durante as operações de plantio e colheita, em função do alto grau de infectividade do suco de colmos contendo células bacterianas de $C$. $x$. susp. $x y l i$ (Steindl, 1961). Como consequiência, as estratégias de controle da doença são, quase que exclusivamente, baseadas nos princípios de exclusão, terapia e imunização, através da descontaminação de equipamentos de plantio e colheita, da formação de viveiros para produção de mudas sadias e do uso de genótipos resistentes, respectivamente. 


\subsubsection{Descontaminação de ferramentas}

Sabendo-se que a ação do homem, através de seus instrumentos de corte, proporcionando o contato do suco de plantas doentes com tecidos sadios de outras plantas, é o ponto crítico para a disseminação de C. $x$. subsp. xyli (Steindl, 1949), a descontaminação de ferramentas é empregada para limitar a evolução espacial e temporal do RS. No primeiro caso, como a incidência de RS pode variar de um canavial para outro, a descontaminação de equipamentos, no momento da transferência das frentes de plantio ou corte, limita a quantidade de propágulos efetivos do patógeno que chega numa nova área, diminuindo a quantidade de inóculo inicial ou, até mesmo, evitando a introdução da doença num canavial. No caso de evolução temporal, a descontaminação periódica dos equipamentos durante a colheita, embora menos usual, diminui a freqüência de ocorrência de infecções de novas soqueiras decorrentes de colmos doentes e, consequentemente, limita a velocidade de crescimento da doença dentro de um canavial (taxa aparente de infecção $=r$ ). Quanto menor a taxa $r$, maior o tempo necessário para a quantidade de doença atingir nível epidêmico (Vanderplank, 1963; Zadocks \& Schein, 1979) e, consequientemente, maior a longevidade do canavial. Porém, esta estratégia de controle é ineficiente se, no momento da colheita, o canavial possuir sua sanidade já comprometida (alto inóculo inicial para infecção das soqueiras).,

Todas as ferramentas utilizadas, principalmente na colheita, como podões, facas e lâminas de colheitadeiras devem ser descontaminadas. A inativação da alta infectividade do caldo que fica depositado nos instrumentos de corte era realizada, grosseiramente, esfregando-se os facões na terra (Abbott, 1958). Hoje, o uso do calor, através de água fervente ou flambagem, consiste no método mais prático para descontaminar ferramentas pequenas, principalmente podões. Por outro lado, no caso de máquinas de plantio ou colheita justifica-se a pulverização de produtos químicos. Estes devem permanecer por pelo menos cinco minutos nas superfícies das máquinas que entrarão em contato com a planta, para uma completa descontaminação (Steindl, 1961; Teakle, 1983; Gillaspie Jr. \& Teakle, 1989). São recomendados vários químicos, como 
solução de Lysol 5-15\% (uma solução de ácido "cresylic"), Deltol 1\% (mistura que inclui óleo de pinho e para-clorometaxilenol), etanol 50\%, e compostos de amônia quaternária a $1 \%)$.

\subsubsection{Produção de mudas sadias}

A produção de mudas com baixa incidência de RS tem sido conseguida através do tratamento térmico de toletes infectados. Este é o mais velho e amplamente usado método para tratamento de mudas de cana-de-açúcar (Benda, 1978; Gillaspie Jr. \& Davis, 1992).

O tratamento térmico, também chamado de termoterapia, é utilizado para inativar talos bacterianos de $C$. $x$. subsp. xyli em mudas destinadas à formação de viveiros sadios. Assim, a cana-planta de viveiros de mudas tratadas apresenta poucos colmos infectados, ou seja, baixo inóculo inicial (Xo). Em termos epidemiológicos, esta redução no inóculo inicial pode impedir ou retardar o início da epidemia, contribuindo para o controle da doença (Vanderplank, 1963; 1984; Zadocks \& Schein, 1979). Esta medida é bastante eficiente para diminuir a quantidade de RS, podendo um canavial permanecer sadio durante boa parte de seu ciclo, quando a ela se associa descontaminação de ferramentas por ocasião do plantio e colheita. Como o tratamento térmico não apresenta 100\% de eficiência (Lopez-Rosa \& Adsuar, 1970; Matsuoka, 1971), sem esta medida complementar a reinfecção proporcionada por talos bacterianos que resistem ao efeito da temperatura é tão eficiente, a ponto de as plantas apresentarem, após cinco multiplicações sucessivas, o mesmo nível de doença que uma planta de canade-açúcar não tratada (Matsuoka, 1984). Neste caso, o sucesso do tratamento térmico fica comprometido.

A significativa contribuição dada pela redução do Xo ao controle do RS se deve, em grande parte, ao fato de que a disseminação do patógeno é altamente dependente da ação do homem, através de seus instrumentos de corte. Diminuindo a ação deste fator crítico, através da descontaminação de equipamentos de plantio e 
colheita, a velocidade de crescimento da doença (taxa aparente de infecção $=r$ ) de um ano para outro (caráter poliético da epidemia, segundo as definições de Vanderplank (1963)) se torna altamente dependente do Xo proporcionado pelas mudas em canaplanta. Por este motivo, uma redução drástica no Xo pelo uso de mudas garantidamente sadias representa também uma diminuição considerável na quantidade final de doença. Consequentemente, evita-se que a quantidade de doença atinja nível epidêmico durante ou ao longo das soqueiras, aumentando a longevidade do canavial.

Embora se tenha notícia da eficiência do uso de ar ou vapor quente, o tratamento com água aquecida a $50,5^{\circ} \mathrm{C}$ por 2 horas é a via preferível, devido à possibilidade de melhor controle de temperatura (Antoine, 1957). No entanto, atualmente tem se utilizado também $52^{\circ} \mathrm{C}$ por 30 minutos, visando maior rapidez ao processo (Sanguino, 1989). Apenas a Louisiana-EUA utilizava o ar quente e tentava-se utilizar o vapor quente (Matsuoka, 1984). Porém, tais sistemas foram abandonados pelas dificuldades operacionais e ineficiência que apresentavam. A água possui grande capacidade de aquecimento por unidade de volume, sendo mais eficiente para a cura de doenças na termoterapia. Além disso, o colmo atinge mais rapidamente a temperatura especificada para o controle e menor tempo de tratamento é necessário (Benda \& Ricaud, 1978).

A utilização de tanques de tratamento térmico nos países canavieiros, e principalmente no Brasil, só foi possível com a construção particular de equipamentos que reproduzissem os padrões básicos requeridos para a inativação do agente causal do RS. Desse modo muitas estações experimentais de cana-de-açúcar e algumas empresas canavieiras construiram seus próprios equipamentos com os recursos então disponíveis (Brieger, 1967; Dodson, 1973). As dificuldades para construir-se um bom equipamento são evidentes e com isso a termoterapia era usada em pequena escala no Brasil.

Atentos ao problema, surgiram dois sistemas de tratamento térmico no Brasil: tratamento térmico de gemas isoladas (Silva. 1974) e de toletes (Tokeshi et al., 1983). Os dois sistemas utilizados apresentam a mesma eficiência, sendo que nenhum deles proporcionou a cura absoluta (Gheller, 1986). Por este motivo, a fim de eliminar 
parte das bactérias que escapam aos efeitos da temperatura, bem como as reinfecções que decorrem a partir desta fonte de inóculo, vários ciclos de tratamento térmico são recomendados (Chagas \& Tokeshi, 1988; Matsuoka, 1984; Tokeshi, 1980). No que se refere ao retorno proporcionado pela termoterapia, mencione-se que parcelas formadas com mudas tratadas produziram 14 a $32 \%$ a mais que parcelas não tratadas, quando foram estudados os genótipos CB41-76, CB49-260 e NA56-79 (Matsuoka, 1976; Gheller, 1986).

A redução da germinação, dada pela sensibilidade das gemas à alta temperatura e ataque subsequente de fungos de solo, tem sido outro problema que pode estar constantemente associado ao processo (Antoine \& Ricaud, 1964). Porém, isto tem sido, na maioria dos casos, contornado através de um rigoroso controle de temperatura nos tanques de tratamento, do uso de fungicidas durante ou após o tratamento térmico, pelo cuidado no manuseio da cana tratada, e resfriamento das gemas logo após o tratamento. O conhecimento da capacidade de brotação de cada genótipo (sensibilidade ao tratamento térmico) é de grande valia para estimar a quantidade de gemas necessárias para a formação de um hectare de muda.

Apesar da eficiência do tratamento térmico cíclico e desinfecção de ferramentas para reduzir a incidência de RS em viveiros e canaviais comerciais, o patógeno ainda prevalece na maioria dos países onde programas de controle baseados nestas medidas existem há muitos anos (Chu \& Lee, 1968; Roach, 1992; Damann Jr. \& Hollier, 1991; Damann Jr. et al., 1984). A dificuldade de manter viveiros e campos comerciais livres do RS tem sido atribuída à relutância dos produtores para praticar a termoterapia regularmente, à rápida disseminação do patógeno a partir do resíduo da termoterapia, à não descontaminação de equipamentos de plantio e colheita, do contínuo uso de genótipos suscetíveis (Comstock et al., 1996b) e, numa escala menor, à possível sobrevivência de C. $x$. subsp. xyli no solo (Autrey et al. 1991; Bailey \& Tough, 1991). Pontanto, o uso da produção de mudas sadias deve ser racionalmente integrado à descontaminação de ferramentas e ao uso de genótipos resistentes para efetivamente 
retardar ou impedir a evolução da epidemia (diminuição do Xo e r) e, consequentemente, reduzir as perdas causadas pelo RS a um nível economicamente aceitável.

\subsubsection{Uso de genótipos resistentes}

A integração do uso de genótipos resistentes à produção de mudas sadias e descontaminação de instrumentos de corte é sugerida porque o tratamento térmico de toletes não é $100 \%$ eficiente, persistindo um residual de bactérias ativas dentro dos colmos tratados (Gillaspie Jr. \& Teakle, 1989). A partir deste residual, devido à alta infectividade do caldo de colmos doentes, a doença apresentará uma rápida evolução para áreas vizinhas (evolução espacial), ou dentro do talhão, para as soqueiras subsequentes (evolução temporal). Além disso, muitas vezes, essas medidas de controle não são devidamente conduzidas ou sequer utilizadas. Nestes casos, o uso de genótipos com a capacidade de limitar a freqüência de infecções, a intensidade da colonização de seu tecidos por $C$. $x$. subsp. $x y l i \mathrm{e}$ as perdas decorrentes deste ataque consiste na única maneira de controlar eficientemente o RS. Portanto, a maioria dos programas de melhoramento genético da cana-de-açúcar estão, se não envolvidos, pelo menos preocupados com a execução de atividades de rotina para a obtenção de genótipos resistentes ou tolerantes ao RS.

\subsection{Métodos utilizados para a identificação de genótipos resistentes ou} tolerantes

Inicialmente, o patógeno do RS não era visto, nem sequer conhecido, sendo sua presença reconhecida pela descoloração de tecidos e pelos efeitos indiretos na produção de colmos. Naquela época, a seleção de genótipos resistentes ou tolerantes ao RS era, essencialmente, baseada nos efeitos da doença na produtividade e nas alterações fisiológicas observadas no hospedeiro. Neste último caso, a freqüência de ocorrência de infecções era avaliada com base na presença de pontuações avermelhas na região nodal 
correspondentes à descoloração dos vasos do xilema colonizados pelo patógeno, até então, desconhecido. Relatou-se então a possibilidade de ocorrência de três tipos de resistência ao RS: tolerância, resistência de campo e imunidade. Os genótipos CP29-116, CP52-68 e Q 50 se comportaram como "tolerantes", podendo ser infectados, mas geralmente não apresentando danos significativos; por outro lado, Q 44 e Badila pareciam ter "resistência de campo", ou seja, embora apresentassem pouco desenvolvimento quando inoculadas artificialmente, não apresentavam infecção no campo (Steindl, 1961). Imunidade foi atribuída ao fato de não se conseguir infecção com RS no genótipo H60-6909 (Wismer, 1971). A partir destas informações, Steindl (1974) sugeriu o controle do RS com genótipos resistentes e/ou tolerantes, desde que se estivesse preparado para conviver com a doença e na dependência de tais materiais.

Logo após a associação do RS a uma bactéria habitante dos vasos do xilema (Gillaspie Jr. et al., 1973; Maramorosch et al., 1973; Teakle et al., 1973), a possível correlação entre anatomia vascular e resistência à doença foi relatada, sugerindo a maior ramificação dos vasos do xilema na região nodal como um mecanismo de resistência estrutural pré-formada em genótipos que não sofriam perdas (Teakle et al., 1975b; 1978). Estimado indiretamente pelo fluxo de água através de nós de colmos sadios, esse mecanismo não era, contudo, suficiente para justificar o nível de resistência de diferentes genótipos (Davis \& Harrison, 1987; Valarini \& Tokeshi, 1981). O grupo do professor Dr. Hasime Tokeshi iniciou então um trabalho, que perdurou por um tempo equivalente à realização de cinco dissertações de mestrado (Chagas, 1986; Cruz, 1983; Douglas, 1981; Iamauti, 1990; Valarini, 1978) e uma tese de doutorado (Chagas, 1996), para selecionar genótipos com base na obstrução dos vasos do xilema e conseqüente diminuição no fluxo de água e fluxo transpiratório, ou seja, medição indireta de alterações fisiológicas induzidas pela bactéria do RS em colmos de cana-de-açúcar. Paralelamente, principalmente com o isolamento (Davis et al., 1980) e classificação do patógeno do RS como C. $x$. subsp. xyli (Davis et al., 1984), surgiram métodos de diagnose mais específicos e precisos (Gillaspie Jr. et al., 1973; Harrison \& Davis, 1990), possibilitando que a seleção de genótipos resistentes possa também ser orientada por 
parâmetros epidemiológicos relacionados ao ciclo das relações patógeno-hospedeiro, como taxa de infecção (Harrison \& Davis, 1986; Sanguino, 1993), eficiência da disseminação (Damann Jr., 1992; Comstock et al., 1996b) e intensidade de colonização de colmos de cana-de-açúcar (Comstock et al., 1996a; Davis et al., 1994; Miller et al., 1995).

\subsubsection{Diferença de produção entre parcelas sadias e doentes e} resistência ao RS (Dados de Produção = DP)

Após a descoberta do RS no genótipo Q 28, em 1944-45, na Austrália, essa doença passou a ser responsabilizada pelo gradual declínio de produção de alguns genótipos cultivados na época, e pelo descarte de muitos clones promissores selecionados nas fases iniciais dos programas de melhoramento, que perdiam o vigor antes de serem liberados comercialmente (King \& Steindl, 1953). Diante deste fato, testes de comparação da produção entre parcelas sadias e inoculadas com caldo de plantas doentes, visando avaliar a resistência e/ou tolerância de genótipos ao RS receberam a atenção dos pesquisadores. Pioneiros no uso desta técnica, Hughes \& Steindl (1955) observaram que o RS acentuava os efeitos do déficit hídrico, nas horas mais quentes do dia. A partir destas informações, dois experimentos foram montados nas Ilhas Maurício para estimar a reação de genótipos ao RS (Antoine, 1959), utilizando o método da comparação da produção de plantas sadias (tratadas termicamente) e doentes (inoculadas) (DP). Nove genótipos foram incluídos nos testes, onde a parcela experimental correspondia a quatro sulcos com 24 touceiras de cana cada, sendo o número de repetições igual a três. Este método foi consagrado na Louisiana, EUA, onde existia uma rotina de teste de novos genótipos utilizando pequenas parcelas de campo com dois genótipos controles e quatro ou cinco repetições. A performance da produção era estendida para a primeira soca e a performance de seis a oito novos genótipos era avaliada a cada ano (Abbott \& Zummo, 1962; Steib, 1974). De maneira semelhante, professores da "Louisiana State University" determinaram que o RS contribuiu em 
grande parte para o declínio de produtividade de genótipos cultivados naquele estado, de 1930 a 1950, ao avaliarem o ganho de produção proporcionado pelo tratamento das mudas destes genótipos com ar quente (Steib \& Chilton, 1968). A mesma estratégia foi adotada para avaliar a resistência ou tolerância ao RS de novos genótipos em Queensland (Hughes \& Steindl, 1971) e na África do Sul (Bechet, 1976).

A aceitação plena do método, apesar de sua eficiência no que diz respeito à seleção dos materiais resistentes ou tolerantes, esbarrava no considerável custo operacional e na exigência em mão-de-obra e espaço de terra para a instalação dos ensaios. Este fato fez com que Wismer (1971), no Havaí, modificasse o delineamento experimental, utilizando uma única planta como parcela, a qual era repetida 20 vezes. Este procedimento permitiu o autor avaliar a resistência ou tolerância ao RS de 34 genótipos havaianos, em fases preliminares do programa de melhoramento daquele estado. Da mesma forma, sete genótipos resistentes ou tolerantes foram identificados entre 16 genótipos testados, na "Sugarcane Field Station", Canal Point - Flórida (Dean, 1983). Para tanto, o Dr. Jack L. Dean montou dois ensaios denominados "Single-Stool Plots": um em maio de 1978 (11 genótipos testados: 20 repetições) e outro em junho de 1979 (21 repetições para cada um dos nove genótipos testados).

No Brasil, embora sob consultoria do havaiano Dr. Chester A. Wismer de 1971 a 1977, o Dr. Sizuo Matsuoka, fitopatologista do então jovem programa de melhoramento genético da cana-de-açúcar do IAA/Planalsucar (hoje Centro de Ciências Agrárias da Universidade Federal de São Carlos), desconhecia o uso de "Single-Stool Plots" para "screening" visando resistência ou tolerância ao RS (Matsuoka, 1997, comunicação pessoal). No entanto, baseando-se em informações de outros patossistemas (Briggs \& Shebeski, 1971; Frey, 1965; Jensen \& Robinson, 1969), utilizou microparcelas para comparar a produção de plantas sadias e doentes (Matsuoka, 1980). O método consiste em plantar gemas isoladas de mudas sadias e com RS, obtidas de viveiros pré-formados, em sacos plásticos contendo solo. Posteriormente, as plântulas obtidas são transplantadas para microparcelas demarcadas no campo. Após a colheita, através de análises estatísticas, compara-se a produtividade das subparcelas sadias e 
doentes para cada cultivar. Utilizando o desenho experimental de parcelas subdivididas, Matsuoka (1980) apresentou os resultados de dois experimentos para comparar a produção de sub-parcelas (quatro plantas) sadias e doentes. Cada genótipo (17 e 21 genótipos nos experimentos I e II, respectivamente) foi repetido quatro vezes. Um terceiro ensaio com sub-parcelas constituídas por dois sulcos de $6,7 \mathrm{~m}$ foi instalado para comparar os resultados do microparcelas com o sistema comercial de plantio (toletes de três gemas). Após análises estatísticas, foi possível classificar os genótipos em quatro classes: altamente suscetíveis, moderadamente suscetíveis, tolerantes e altamente tolerantes. A performance dos genótipos CB41-14, CB41-76, IAC52-326 e NA56-79, comuns aos testes I e/ou II e III, foi semelhante, mostrando ter havido uma boa correlação entre os níveis de tolerância ao RS estimados pelo microparcelas (parcelas espaçadas) e pelo plantio comercial em alta densidade.

A vantagem do microparcelas em relação ao "Single-Stool Plots" é que o primeiro possui parcelas maiores (quatro plantas) e, como conseqüência, o erro experimental e a interferência entre parcelas são diminuídos, possibilitando o uso de poucas repetições (quatro). Assim, microparcelas constitui-se numa técnica de considerável valor para a determinação da resistência ou tolerância ao RS, onde o probema de espaço e trabalho é crítico. A importância do uso de parcelas reduzidas fica ainda mais evidente, ao se considerar que o dano causado pelo RS em um genótipo específico é influenciado pelas condições do solo como tipo, fertilidade (Wang, 1966) e umidade (Rossler, 1974; Steindl, 1961; Wang, 1966), levando à necessidade de conduzir pelo menos dois experimentos em diferentes anos e/ou locais para obtenção de resultados confiáveis. Esta atividade seria dificilmente praticada com parcelas grandes que requerem muito mais área e trabalho.

A versatilidade do microparcelas sugere seu uso para que se conheça o nível de resistência ou tolerância de genótipos promissores, antes da liberação dos mesmos para cultivo comercial, principalmente em programas de melhoramento onde muitos deles atingem potencial de liberação a cada ano (Matsuoka, 1980). Neste caso, o número de genótipos a serem testados pode ser dividido em grupos pequenos, sendo 
estes testados em locais e/ou anos distintos. Através de comparações estatísticas, a resistência ou tolerância relativa de genótipos melhorados em anos diferentes pode ser comparada, incluindo os mesmos genótipos padrões em todos os testes. Porém, a necessidade de realização de vários testes para dar credibilidade aos resultados tem, até certo ponto, incentivado os pesquisadores na busca de alternativas mais rápidas e eficientes para selecionar genótipos que não apresentem danos pelo RS. Além disso, DP não separa resistência de tolerância, podendo a produção de um genótipo não ser afetada por este tolerar o RS (tolerância) ou por limitar o sucesso das relações patógenohospedeiro que caracterizam o processo de doença (resistência). Esta confusão pode trazer complicações, quando há interesse em integrar o uso de tratamento térmico, testes de sanidade de viveiros e descontaminação de ferramentas de corte de mudas com genótipos tolerantes, visando manejar a cultura canavieira para melhor controlar o RS. Para maior racionalidade das operações, estas medidas deveriam ser aplicadas para reduzir a infecção em canaviais implantados com genótipos tolerantes ou suscetíveis, sendo desnecessárias quando se utilizar genótipos resistentes. Portanto, microparcelas ou qualquer outro método que utiliza o princípio da comparação de produção de parcelas sadias e doentes deve ser aplicado conjuntamente com técnicas que avaliam o grau de infecção e/ou colonização da planta pelo patógeno para possibilitar a separação de genótipos resistentes daqueles tolerantes.

\subsubsection{Anatomia vascular como fator determinante da resistência}

A hipótese da possível correlação entre anatomia vascular e resistência ao RS foi testada por Teakle et al. (1975b). Para tanto, os autores utilizaram um método que determinou a resistência ao movimento de água pela região nodal de 11 genótipos de cana-de-açúcar com diferentes reações de imunidade, tolerância e suscetibilidade. $\mathrm{O}$ método consistia em medir o fluxo de água que atravessava nós isolados sadios (com respectivas partes dos entrenós) quando se aplicava uma pressão de vácuo de $27 \mathrm{~mm}$ de 
$\mathrm{Hg}$ (método do fluxômetro). De maneira similar, porém utilizando dois nós, media-se a habilidade da tinta da índia (suspensão coloidal de partículas de carbono) de atravessar os vasos, avaliando-se o número de feixes vasculares escurecidos pela passagem do corante. Resultados dos dois testes demonstraram ocorrer a correlação entre resistência ao movimento de água através dos feixes vasculares e resistência à bactéria, sugerindo que estudos sobre a anatomia vascular poderiam elucidar os mecanismos envolvidos. Um resultado interessante obtido pelos autores foi que não havia correlação entre diâmetro dos colmos dos genótipos estudados e fluxo de água. Concluíram então que a utilização do método do fluxômetro para identificação de genótipos resistentes ao RS seria interessante, uma vez que, como foi relatado por Cho et al. (1973), a resistência baseada em caracteres morfológicos (como anatomia vascular) é muito valiosa, por ser extremamente estável.

Em estudos sobre as bases anatômicas envolvidas na resistência ao RS em cana-de-açúcar, Teakle et al. (1978) utilizaram o método do fluxômetro para verificar os efeitos do diâmetro dos colmos e de outras doenças (podridão vermelha causada por Physalospora tucumanensis) na taxa de fluxo de água em diferentes genótipos. Realizaram investigações sobre a anatomia dos feixes vasculares do xilema em microscópio ótico comum e utilizaram o microscópio eletrônico na implementação desses estudos. Verificaram que os genótipos resistentes (que possuíam fluxo de água lento) apresentavam maior ramificação nos vasos do metaxilema na região nodal se comparados aos clones suscetíveis. Para os autores, era plenamente compreensível que tal fenômeno ocorresse, pois os vasos ramificados tinham diâmetro e poros pequenos, o que determinava uma menor vazão de água. Concluíram então que características intrínsecas da anatomia vascular na região nodal dos colmos estariam envolvidas como mecanismos de resistência restringindo a distribuição do patógeno ao longo do xilema. Porém, o menor poro existente nas células do metaxilema era maior que a bactéria do RS, de maneira que apenas diferenças anatômicas não eram suficientes para explicar a imunidade freqüentemente apresentada pela H60-6909 (um dos clones testados), sendo possível que a produção de gomas e tiloses, estivessem também envolvidas na 
resistência ao RS. Mais tarde, Valarini (1978) e Davis (1985) verificaram que, na comparação da diferença na condução de água em plantas infectadas e não infectadas com RS de distintos genótipos, a correlação com resistência a essa doença não é verdadeira. Somente comparação dentro do mesmo genótipo ("sadio" e "doente") foi diretamente correlacionada com resistência ao RS. Portanto, a maior ramificação dos vasos do xilema na região do nó, caracterizada pelo menor fluxo de água através dos nós sadios, não é um bom parâmetro para seleção de genótipos resistentes a $C$. $x$. subsp. xyli. Além disso, consiste num método bastante trabalhoso, impossibilitando testes que envolvam grande número de genótipos.

\subsubsection{Funcionalidade dos vasos do xilema e resistência ao RS}

Os estudos de Teakle et al. (1975b; 1978) serviram como base para o desenvolvimento de outra estratégia para selecionar genótipos de cana-de-açúcar resistentes ao RS: quantificação dos efeitos diretos da colonização dos vasos do xilema por $C$. $x$. subsp. xyli na funcionalidade deste vasos e, consequentemente, no fluxo transpiratório da planta (Chagas, 1986; Chagas, 1996; Chagas \& Tokeshi, 1994ab; Cruz, 1983; Douglas, 1981; Iamauti, 1990; Iamauti \& Tokeshi, 1994; Valarini, 1978).

O método do fluxômetro (Teakle, 1975b) foi adaptado, de maneira a permitir a avaliação da vazão de água através dos colmos de parcelas sadias e inoculadas com RS (Valarini, 1978). Através da diferença de vazão entre os dois tratamentos (sadio e RS), genótipos foram classificados em diferentes níveis de resistência à doença. Genótipos resistentes apresentaram pequena diferença de vazão, sendo que o oposto ocorria para os genótipos suscetíveis. Além disso, através da contagem de vasos funcionais enegrecidos pela substituição da água por tinta nanquin, Valarini (1978) demonstrou que a vazão de água nos colmos foi diretamente proporcional ao número de vasos funcionais do xilema, ou seja, o método foi capaz de avaliar a interferência de $C$. $x$. subsp. xyli no transporte de seiva bruta na planta. Genótipos tolerantes apresentaram 
menor perda na sua capacidade de transporte de água, enquanto nas suscetíveis a perda era grande.

A eficácia do método do fluxômetro foi comprovada pela boa correlação entre a resistência ao RS identificada pelo mesmo e aquela determinada por resultados de medidas de produção, também chamados de dados de produção - DP (Douglas, 1981). Para tanto, foram realizadas pesagens de canas de segundo corte originadas de tratamento térmico (sadia) e outras inoculadas com caldo bruto de plantas com sintomas da doença (RS). A diferença de produção foi então comparada com a diferença de vazão de água através do fluxômetro, para cada genótipo estudado. Posteriormente, substituindo a água e nanquin por uma solução corante (água + safranina O), foi demonstrada mais uma vez a boa correlação entre vazão de água e número de vasos funcionais (Cruz, 1983).

Com o objetivo de se ter maior praticidade, Davis \& Harrison (1987) propuseram uma modificação no método do fluxômetro, utilizando pressão hidrostática para avaliar a diferença de vazão entre parcelas sadias e doentes, em vez da bomba de vácuo. Comparam os resultados com danos na produção relatada anteriormente por Dean (1983), sendo demonstrada a correlação positiva entre resistência à condução de água e tolerância ao RS. Porém, não existem outros relatos a respeito do desenvolvimento do método da condutividade hidráulica que comprovassem a maior praticidade sugerida pelos autores.

Diante do exposto, o método do fluxômetro foi considerado eficiente, seguro e exeqüível em programas de melhoramento, visando a identificação de genótipos resistentes ao RS. Porém, a aplicação do método exigia grande atenção, devido aos vários fatores que interferiam nos resultados, entre os quais a pressão de vácuo, o período de armazenamento dos colmos, as doenças vasculares, a broca do colmo (Diatraea saccharalis), a idade dos colmos, a distribuição da doença dentro da touceira (Valarini \& Tokeshi, 1981), a umidade do solo (Douglas, 1981), e a ocorrência de Escaldadura-das-folhas (Cruz, 1983). 
Em função das dificuldades do uso do fluxômetro em testes de rotina em programas de melhoramento da cana-de-açúcar, onde grande volume de material devia ser manuseado, Chagas (1986) desenvolveu o método de coloração do xilema (MCVX), substituindo a bomba de vácuo pelo fluxo transpiratório da própria planta funcionando como "bomba de sucção" de água. A coloração dos vasos do xilema foi feita por uma solução corante (Safranina O a 2,5\% em ethanol 95\%, diluída em água na proporção $1: 10)$ a qual era succionada pelo fluxo transpiratório natural promovido pelas folhas da cana-de-açúcar. Para isso, colmos inteiros e com folhas, colhidos pela manhã, após serem novamente cortados entre o terceiro e quarto nó, eram imediatamente introduzidos em recipientes contendo a solução corante, onde permaneciam durante 60 minutos. Posteriormente, os colmos eram retirados da solução e a avaliação era realizada observando-se a quantidade de vasos funcionais (coloridos de vermelho), comparando com uma escala desenvolvida pelo próprio autor. Desta forma, era conhecido o índice de contaminação (IC) pelo RS (\% de vasos não funcionais), parâmetro que apresentou correlação positiva com vazão de água em colmos oriundos de mudas tratadas termicamente (sadios) e de mudas inoculadas (doentes).

A evolução dos métodos para avaliar a interferência de RS no fluxo transpiratório, eliminando o uso da bomba de vácuo, transformou a avaliação de RS pelo fluxômetro num método mais eficiente, econômico e prático, sem perder a precisão. Estes resultados permitiram Chagas (1986) prever a utilização do MCVX para a seleção de genótipos resistentes.

Utilizando o método de Chagas (1986), Iamauti (1990) determinou a resistência de genótipos de cana-de-açúcar ao RS, através da diferença entre o índice de contaminação de parcelas sadias e doentes. Para tanto, quatro genótipos padrões possuíam duas linhas de 20 metros de comprimento com colmos sadios e outras duas de igual tamanho com colmos doentes, enquanto os sete genótipos-teste tinham apenas uma linha de cada tratamento (sadio e doente). A unidade experimental era representada por cada touceira de cana-de-açúcar existente na linha, sendo coletados colmos de touceiras diferentes de cada um dos tratamentos. Diante desse delineamento experimental, 
nenhum método estatístico paramétrico pôde ser aplicado e, por este motivo, foi utilizado o teste do sinal, apropriado à análise de dados pareados e descrito por Campos (1983), para testar a hipótese Ho: $X=Y$, ou seja, verificar se ocorria ou não diferença de IC entre as parcelas sadias e doentes. Ausência de diferença caracterizava genótipos resistentes, enquanto diferença significativa indicava suscetibilidade. Os resultados obtidos pela autora demonstraram a capacidade do método da coloração do xilema para identificar resistência, quando se comparavam parcelas sadias e doentes para cada genótipo. Porém, genótipos com resistência intermediária ao RS não foram facilmente identificados pela coloração do xilema. Por este motivo, comparado com o método de detecção da presença de $C$. $x$. subsp. xyli nos colmos pela contagem da bactéria em microscópio de contraste de fase (Gillaspie Jr. et al., 1973), o método de coloração foi considerado de menor sensitividade. A observação da bactéria permitiu a detecção da suscetibilidade de genótipos ainda na fase inicial do processo patológico.

Embora o IC seja uma medida de severidade da doença, Iamauti (1990) não pôde se valer desse caráter quantitativo, pois o delineamento experimental utilizado por ela não permitia uma gradação de níveis de resistênica pela comparação entre genótipos, ou seja, apenas resistencia e suscetibilidade era avaliada pela comparação entre parcelas sadias e doentes de cada genótipo. Para tanto, Chagas (1996) modificou o delineamento experimental de Iamauti (1990), montando um experimento com parcelas subdivididas ("sadias" = tratadas termicamente, e "doentes" = inoculadas com RS) distribuídas em blocos casualizados com seis repetições, permitindo análise estatística paramétrica dos resultados. Além de quantificar o IC, o autor estimou os danos em produtividade agro-industrial a fim de avaliar também a tolerância dos genótipos testados. Porém, devido a possíveis problemas com o tratamento térmico e/ou baixa eficiência da inoculação, parcelas sadias e doentes apresentavam níveis de IC muito próximos.

Nos 10 genótipos estudados em cana-planta, a amplitude da diferença de IC entre doente e sadia (IC da doente - IC da sadia) foi de 1,00 a 6,69\%, sendo que o IC variou desde 9,58 a $19,21 \%$ e 11,13 a $23,60 \%$ nas parcelas tratadas termicamente 
(sadias) e inoculadas com RS (doente), respectivamente. Por este motivo, não foi possível a gradação de níveis de resistência através da comparação de IC entre genótipos. Mais uma vez recorreu-se à diferença de IC e de produtividade entre parcelas sadias e doentes dentro de cada genótipo. Utilizando-se deste recurso, foi demonstrada a sensibilidade do método de coloração de xilema pelo fluxo transpiratório para identificar genótipos com suscetibilidade, resistência, tolerância e intolerância, em função da diferença de IC e produtividade entre parcelas sadias e doentes. A credibilidade do método foi assim implementada, pois tendências de danos de produtividade agroindustriais puderam ser expressas em função do IC, através de modelos de regressões lineares para sete dos 10 genótipos estudados em cana-soca (70\% do total), embora o desenho experimental não fosse adequado para tal estudo (os diferentes níveis de doença de cada genótipo foram obtidos casualmente, pois o modelo só previa dois níveis, a saber: inoculado e tratado termicamente)

Diante do exposto, o método de coloração do xilema, quando aliado à medida de produtividade agro-industrial, contitui-se numa excelente ferramenta à disposição de melhoristas e/ou fitopatologistas para a eliminação de clones suscetíveis e intolerantes ao RS. Com relação à diagnose em si, trata-se de um método eficiente, econômico e prático, comparado aos processos existentes. Porém, a identificação de genótipos resistentes demanda trabalho e custo duplo por exigir parcelas sadias e doentes, além de ser, até certo ponto, qualitativa, ou seja, sem gradação de níveis, separando apenas as resistentes e suscetíveis (estatística aplicada dentro de genótipos). Outro aspecto negativo é que trata-se de um método indireto de diagnose não dando nenhuma informação a respeito da colonização dos vasos por $C$. $x$. subsp. $x y l i$. Surge então a hipótese de que uma genótipo classificado como resistente pelo MCVX (baixo IC = muitos vasos funcionais) possa, na verdade, suportar intensa colonização de seus vasos pela bactéria do RS sem, contudo, ter o fluxo transpiratório afetado na mesma proporção. 


\subsubsection{Resistência de cana-de-açúcar à infecção por $C$. $x$. subsp. xyli}

Logo após a constatação do RS na Austrália, em 1944-45, a porcentagem de colmos infectados passou a ser avaliada pela relação entre colmos com sintomas de descoloração dos vasos do xilema na região nodal e colmos sem sintomas (Steindl, 1961; Wismer, 1971). Embora este tipo de diagnóstico tenha sido utilizado para relatar a doença em diferentes partes do mundo, os sintomas internos em colmos maduros são inespecíficos e, em alguns casos, ausentes. Portanto, somente após o surgimento de métodos de diagnose mais precisos, a taxa de infecção pôde ser avaliada em diferentes genótipos. A resistência de cana-de-açúcar à infeç̧ão por $C$. $x$. subsp. xyli foi então avaliada por Harrison \& Davis (1986), com base na diagnose pelo microscópio de contraste de fase (Gillaspie Jr. et al., 1973). Genótipos resistentes apresentaram valores de ED50 (concentração de bactéria necessária para infectar 50\% das plantas inoculadas) da ordem de $10^{8}$ células $/ \mathrm{ml}$, enquanto, as suscetíveis, em torno de $10^{4}$ células $/ \mathrm{ml}$. Estes valores foram estimados através de regressões matemáticas entre a concentração de bactérias e a porcentagem de plantas infectadas. Para tanto, foi necessário um experimento trabalhoso ("infectivity titration experiment") envolvendo inoculações de toletes com suspenções bacterianas a diferentes concentrações $\left(10^{9}, 10^{7}, 10^{5}, 10^{3}, 10^{1} \mathrm{e}\right.$ zero células/ml), avaliando-se a porcentagem de plantas infectadas em cada tratamento (Harrison \& Davis, 1986).

No Brasil, Sanguino (1993) utilizou a microscopia de contraste de fase para avaliar resistência de 10 genótipos de cana-de-açúcar ao RS, com base na porcentagem de colmos infectados. Na média de três corte, esse parâmetro variou desde 24 a 98\%, demonstrando que todos os genótipos testados apresentavam certo grau de infecção por $C$. $x$. subsp. $x y l i$. Dois genótipos se comportaram como mais resistentes, e oito como suscetíveis. Comparando a infecção com a diferença de peso entre parcelas sadias e doentes expressa em porcentagem, foi também estimado o nível de tolerância de cada genótipo. SP70-1423 e SP71-1406 mostraram-se tolerantes ao RS, pois 
apresentaram alta incidência de doença ( $98 \%$ e $86 \%$, respectivamente) sem que houvesse danos em produtividade devido à ocorrência da doença.

Diante do exposto, o método de contagem da bactéria em microscópio de contraste de fase, aliado à medida de produtividade de parcelas sadias e doentes, permitiu a identificação de genótipos suscetíveis, tolerantes e resistentes. Porém, a intensidade do RS expressa pela incidência (porcentagem de colmos infectados) é um parâmetro qualitativo, não dando nenhuma informação a respeito do nível de colonização dos tecidos do xilema de cada genótipo estudado. Portanto, não fica cientificamente descartada a hipótese de que os genótipos identificados por Sanguino (1993) como tolerantes sejam, na verdade, resistentes à colonização da bactéria. Neste caso, menor densidade populacional no suco extraído dos vasos dos xilema determinaria menor número de vasos colonizados e, consequentemente, menor dano causado pelo RS (Davis et al., 1988b). Portanto, torna-se necessária a quantificação da severidade do RS, definida aqui como o nível populacional da bactéria no suco extraído dos colmos ou a intensidade da colonização dos tecidos do hospedeiro por $C$. $x$. subsp. $x y l i$.

\subsubsection{Resistência de cana-de-açúcar à colonização por $C$. $x$. subsp.}

xyli

Depois de Plavsic-Banjac \& Maramorosch (1972) terem observado bactérias nos vasos do xilema de colmos de cana-de-açúcar com sintomas de RS, através de exames em microscópio eletrônico e eletromicrografia, vários trabalhos têm demonstrado ser a resistência de genótipos de cana-de-açúcar ao RS devido à menor densidade populacional da bactéria em colmos infectados (Bailey, 1977; Davis et al., 1988a; Gillaspie Jr. et al., 1976; Koike et al., 1982).

$\mathrm{Na}$ tentativa de desenvolver um método de identificação de genótipos resistentes com base na densidade populacional da bactéria do RS, Gillaspie Jr. et al. (1973) estimaram a quantidade de células bacterianas em suco extraído de colmos dos genótipos CP44-101, CP65-367, L62-96 e L65-69. A extração foi feita através da 
moagem dos colmos com seis meses de idade e a contagem de talos bacterianos no suco obtido com o auxílio de microscópio de contraste de fase. Esses autores sugeriram o uso desse método e concluíram que a parte basal (principalmente os nós) dos colmos continha mais bactérias, que as amostras poderiam ser conservadas em baixas temperaturas até duas semanas, e que a observação não necessitava ser imediatamente após a extração. O número de bactérias não foi igual nos diferentes genótipos e entre as plantas do mesmo genótipo, sendo que canas apresentando sintomas conspícuos do RS continham mais bactérias do que aqueles com sintomas indistintos.

Mais tarde, Gillaspie Jr. et al. (1976) estudando clones resistentes e suscetíveis inoculados com RS comprovaram que o caldo bruto dos clones suscetíveis apresentavam um maior número de bactéria, em relação ao caldo dos clones resistentes. Desta forma, os autores afirmaram que a correlação negativa entre nível de resistência ao RS e o número de bactéria no suco do xilema indicava que a contagem da densidade populacional da bactéria, através de microscopia de contraste de fase, poderia se constituir num vantajoso método para identificação de genótipos resistentes ao RS. O método consiste em extrair o caldo dos colmos ou suco dos vasos do xilema, colocar algumas gotas sobre uma lâmina de microscopia, cobrir com lamínula e observar em microscópio de contraste de fase com aumento de 1000 a 1200 vezes. A presença de movimento browniano devido ao reduzido tamanho da bactéria do RS facilita a observação do microrganismo com o uso do microscópio de contraste de fase. Porém, é preciso atentar para alguns detalhes, como idade dos colmos amostrados e condições de crescimento das plantas. A maior variação nos trabalhos está no método de extração do suco do xilema ou caldo dos colmos e na sua purificação. Extração do suco vascular do entrenó de colmos de cana mediante bomba de vácuo, centrifugação a $3.000 \mathrm{rpm}$ por uma hora, suspensão do pellet em água destilada estéril e observação em aumento de 1.250 vezes foi o método empregado por Steindl (1976), que modificou a extração utilizada por Gillaspie Jr. et al. (1973).

Teakle et al. (1975a) propuseram outra alteração no método de extração, onde os colmos eram lavados, descontaminados superficialmente, descascados e finas 
secções dos nós e entrenós eram retiradas assepticamente e deixadas em $25 \mathrm{ml}$ de água destiladas estéril por duas horas. Após este período, a água contendo as bactérias era filtrada e centrifugada a $14.000 \mathrm{~g}$ por 30 minutos a $5^{\circ} \mathrm{C}$ para manter a assepsia, os pellets ressuspendidos em água estéril, eram observados em microscópio de contraste de fase com aumento de 1.000 vezes. Com esta técnica foi possível eliminar bactérias saprófitas e outros habitantes do sistema vascular dos colmos de cana-de-açúcar concomitante à obtenção de uma adequada concentração da bactéria associada ao RS.

A utilidade do microscópio de contraste de fase foi demonstrada mais tarde por Bailey (1977) ao descrever a existência de uma relação direta entre severidade de reações dos genótipos afetados pelo RS e o número de bactérias observadas em preparação de tecidos de todas as partes das plantas. Entretanto, devido ao baixo número de bactérias observadas em tecidos da parte apical do colmo e em tecidos de colmos jovens, torna-se necessário o uso de secções de colmos maduros, para uma maior segurança na determinação da densidade populacional da bactéria do RS.

$\mathrm{Na}$ tentativa de tornar o método aplicável em larga escala para avaliar resistência de clones ao RS, Koike et al. (1982) avaliaram a possível correlação entre produção e contagem de bactérias em microscópio de contraste de fase, durante três anos. Verificaram então que a correlação ocorria para os genótipos resistentes (que não sofreram perdas de produção e apresentaram pequeno número de bactérias) e para genótipos suscetíveis (perda de produção e grande número de bactérias). Para genótipos intermediários os resultados não se mostraram consistentes, e os dados de produção sugeriram que dentro do grupo dos intermediários existem genótipos resistentes e suscetíveis. A contagem se mostrou eficiente para identificar genótipos extremamente resistentes ou suscetíveis, e, apesar desta limitação quanto à sensibilidade do método, os autores consideraram-na útil para identificação de genótipos resistentes ao RS. Um detalhe interessante observado na metodologia de extração e contagem de bactérias é que amostras congeladas para observação posterior e amostras frescas apresentavam os mesmos resultados. 
A identificação e contagem das células da bactéria do RS pelo método do microscópio de contraste de fase seria muito trabalhosa em programas que manuseiam grande volume de genótipos, a cada ano. Por esse motivo, após o isolamento e classificação da bactéria do RS, foi desenvolvida a técnica de contagem direta de anticorpo fluorescente (fluorescent-antibody-direct-count = FADC) em filtros (Davis, 1985). A reação específica do antissoro com $C$. $x$. subsp. $x y l i$ possibilita a contagem de células bacterianas que ficam fluorescentes (avermelhadas) sob o microscópio de epifluorescência. Desta forma, a técnic a detecta pelo menos $10^{4}$ células $/ \mathrm{ml}$, sendo 10 vezes mais sensitiva que o microscópio de contraste de fase.

FADC foi utilizada para estudar a distribuição e variabilidade quantitativa de populações de $C$. $x$. subsp. $x y l i$ em colmos de genótipos de cana-de-açúcar diferindo quanto à resistência ao RS (Davis et al., 1988ab). Tanto a velocidade de crescimento como a quantidade máxima da população do patógeno atingiram valores mais elevados nos suscetíveis, quando um total de nove genótipos foram amostrados em três épocas sucessivas. Internódios maduros apresentaram maior densidade populacional em relação aos mais jovens, sugerindo a necessidade de se testar genótipos em fases mais adiantadas do ciclo de crescimento da planta. À medida em que os tecidos ficavam maduros melhor correlação entre densidade populacional de $C . x$. subsp. xyli e danos na produção era observada. Estas informações animaram o Dr. Davis na sua busca por um método eficaz para identificar genótipos resistentes ao RS. Em 1988, sob sua orientação, o Dr. Harrison conclui seus trabalhos de Pós-doutoramento apresentando a técnica que hoje é de grande utilidade em programas de melhoramento de cana-de-açúcar para quantificar a colonização de tecidos vasculares por $C$. $x$. subsp. xyli: "Tissue-blot enzyme immunoassay"-TBIA (Harrison \& Davis, 1988).

O processo TBIA é constituído por diversas etapas. Primeiramente, cilindros de tecido da região central dos entrenós de colmos de cana-de-açúcar são amostrados. Este tecido é centrifugado de maneira a coletar o suco de cada feixe vascular em membrana de nitrocelulose. Após processamento serológico, feixes vasculares colonizados por $C$. $x$. subsp. xyli são identificados na membrana pela coloração azulada, 
quando observados através de microscópio estereoscópico. Depósitos coloridos de dimensões similares à de um metaxilema individualizado podem ser observados em membranas processadas.

Com o TBIA foi demonstrado que a resistência de genótipos de cana-deaçúcar estava associada com uma redução na colonização dos tecidos vasculares do colmo por C. $x$. subsp. xyli (Harrison \& Davis, 1988). Nesse mesmo trabalho, os autores obtiveram excelente correlação $(r=0,97)$ entre o número de vasos colonizados $(\mathrm{VC})$ e a densidade populacional do patógeno determinada pela técnica FADC. Além disso, comparação de dados históricos de danos na produção de cana por parcela com VC indicaram certa similaridade no nível de resistência obtido pelos dois parâmetros, o que foi demonstrado mais tarde por Davis et al. (1994). Este fato, aliado à sensibilidade, praticidade e capacidade de processar amostras múltiplas, fez com que o TBIA fosse adotado pelo programa de melhoramento genético da cana-de-açúcar do Estado da Flórida (Comstock et al., 1996a) para estimar incidência (\% de colmos infectados) e severidade (número médio de feixes vasculares colonizados) do RS, visando a identificação e seleção de genótipos resistentes.

Nas estações de melhoramento de Canal Point (FL) e Houma (LO) a técnica tem sido utilizada com sucesso (Comstock et al., 1996a). Porém, Grisham \& Comstock (Informações pessoais) têm alertado para a possibilidade da não correlação absoluta entre VC e danos de produtividade pelo RS, tendo como exemplo o genótipo CP79-318 cujo elevado número de VC não tem repercutido em danos significativos. A existência de genótipos tolerantes levanta a hipótese de que vasos colonizados podem, por vezes, permanecerem funcionais sem comprometer o transporte de água e sais minerais. Neste particular, a associação do TBIA (Harrison \& Davis, 1988) para determinar o número de vasos colonizados e MCVX (Chagas, 1986) para verificar a funcionalidade destes parece, à primeira vista, muito interessante. 


\section{MATERIAL E MÉTODOS}

\subsection{Padronização de método para avaliar a colonização de colmos de cana-de- açúcar por $C$. $x$. subsp. xyli e o respectivo efeito na funcionalidade dos vasos do xilema}

\subsubsection{Método conciliado MCVX/TBIA}

$\mathrm{Na}$ estação de campo do programa de melhoramento genético da cana-deaçúcar de Canal Point (USDA-ARS Sugarcane Field Station), Flórida - EUA, plantas com nove meses de idade dos genótipos CP72-2086, CB41-76 e CP53-1, representado níveis de severidade de RS baixo (Comstock et al., 1997), médio (Douglas, 1981) e alto (Comstock et al, 1996a), respectivamente, foram amostradas. O tamanho da amostra foi de 10 colmos para cada genótipo. Estes colmos foram então utilizados para conciliar TBIA com MCVX, ou seja, tomar ambos passíveis de aplicação num mesmo colmo de cana-de-açúcar, permitindo avaliar a colonização por $C$. $x$. subsp. xyli e seus efeitos na funcionalidade dos vasos do xilema, numa única amostra. Além disso, os colmos foram utilizados para determinar a influência da safranina $O$ no TBIA e analisar a repetibilidade dos resultados obtidos pelo protocolo conciliado MCVX/TBIA.

\subsubsection{Protocolo MCVX/TBIA}

Os métodos MCVX (Chagas, 1986) e TBIA (Harrison \& Davis, 1988) foram conciliados para quantificar a porcentagem de feixes vasculares colonizados por $C$. $x$. subsp. $x y l i(\% \mathrm{VC})$ e a porcentagem de feixes vasculares não funcionais (\%VNF), numa mesma amostra de internódios de colmos de cana-de-açúcar.

A coloração dos xilemas funcionais foi conduzida com pequenas modificações feitas no processo desenvolvido por Chagas (1986). Uma solução corante de safranina 0 em etanol $(2,25 \% \mathrm{p} / \mathrm{v})$ foi diluída na proporção de 1:10 em água. Seis litros da diluição final foram distribuídos em três baldes plásticos com capacidade total 
de oito litros. Posteriormente, 10 colmos de cada genótipo foram limpos (despalhados) e colhidos próximo ao nível do solo, mantendo suas folhas fisiológicamente ativas. Não mais que cinco minutos depois, os colmos foram cortados novamente, na metade do segundo internódio basal, visando eliminar o efeito da cavitação pelo descarte do primeiro nó basal, e imediatamente imersos na solução corante. Após uma hora de coloração, processo resultante da absorção da solução corante pelos vasos do xilema através do fluxo transpiratório da planta, os colmos foram removidos dos baldes e uma secção transversal de $10 \mathrm{~mm}$ de diâmetro e $10 \mathrm{~mm}$ de altura (cilindro) foi amostrada de cada um deles, no centro do terceiro internódio basal. Posteriormente, os cilindros foram acondicionados dentro de poços individuais em placas plásticas, com uma das superfícies do corte transversal do colmo sobre uma membrana de nitrocelulose. A membrana tinha sido colocada sobre camada de papel Whatman de três milímetros de espessura com uma subcamada de papel toalha absorvente e suporte de plástico no fundo. As placas foram então centrifugadas a $1.700 \mathrm{~g}$ por 15 minutos para forçar a saída da seiva do xilema, formando um "pellet" de bactérias sobre a membrana de nitrocelulose diretamente abaixo dos feixes vasculares colonizados pela bactéria do RS. Subsequentemente, os cilindros foram removidos da placa e, no dia seguinte, já secos, foram observados em um estereomicroscópio para se contar tanto o número feixes vasculares funcionais como o de não funcionais, os quais foram identificados pela coloração vermelha e branca, respectivamente. Cada vaso, após sua contagem, foi marcado com uma caneta esferográfica, para evitar sobreposição de contagem. Com estes resultados, calculou-se a porcentagem de vasos não funcionais (\%VNF). As membranas foram então secas em estufa por uma hora a $80^{\circ} \mathrm{C}$ e estocadas, por no máximo uma semana, até serem sujeitadas a um procedimento serológico para detectar os tecidos vasculares infectados por $C$. $x$. subsp. $x y l i$, de acordo com o processo desenvolvido por Harrison \& Davis (1988) e modificado por Davis et al. (1994).

$\mathrm{O}$ processo serológico foi conduzido em um agitador rotatório a $60 \mathrm{rpm}$. As membranas foram bloqueadas durante 30 minutos em tampão Tris $(100 \mathrm{mM}$ Tris- $\mathrm{HCl}$, $150 \mathrm{mM} \mathrm{NaCl}, \mathrm{pH}$ 7,5) mais reagente bloqueador (Boehringer Mannheim) na concentração de $0,5 \%$ (p/v) e lavadas em tampão Tris por 1 minuto. As membranas 
foram então incubadas por uma hora em antissoro contra o strain F-1 de $C$. $x$. subsp. xyli fornecido pelo Dr. M.J. Davis ("Department of Plant Pathology, University of Florida, Homestead") diluído na proporção 1:8.000 em tampão Tris e lavadas três vezes, com o mesmo tampão, durante cinco minutos cada. Após a lavagem, as membranas foram incubadas por uma hora em antissoro de cabra contra IgG de coelho conjugado com fosfatase alcalina (Sigma Chemical Co.) diluído 1:1.000 em tampão Tris e lavadas duas vezes com o mesmo tampão. Subsequentemente, as membranas foram incubadas em solução substrato, no escuro, por 20-30 minutos, até que manchas azul-escuras apareceram nas membranas onde a bactéria do RS de feixes vasculares infectados havia sido depositada. Após incubação na solução substrato, as membranas foram lavadas em solução $1,05 \%$ de hipoclorito de sódio para remover a coloração marrom amarelada distribuída por toda a membrana, seguida de lavagem em água e secagem entre folhas de papel mata-borrão. Após o procedimento serológico, impressões azuladas dos feixes vasculares colonizados (VC) puderam ser vistas e contadas na membranas com o auxílio de um estereomicroscópio. Isto permitiu a quantificação da severidade do RS com base no parâmetro \%VC.

A solução substrato foi preparada pela adição de $30 \mathrm{mg}$ de "napthol AS phosphate" (Sigma Chemical Co.) em $5 \mathrm{ml}$ de "N,N-dimethylformamide" (Sigma Chemical Co.) para $100 \mathrm{ml}$ de 0,2 $\mathrm{M}$ de tampão Tris (tampão substrato Tris, pH 9,1), para colorir $100-\mathrm{cm}^{2}$ de membrana de nitrocelulose. Imediatamente antes do uso, o "working substrate" foi preparado adicionando-se $0,1 \mathrm{~g}$ de "Fast Blue BB Salt" e 0,5 ml de solução $0,1 \mathrm{M}$ de cloreto de magnésio foram adicionados a $100 \mathrm{ml}$ de solução substrato.

\subsubsection{Influência da safranina $O$ na detecção de vasos colonizados pelo método conciliado MCVX/TBIA}

Para o estudo do método conciliado MCVX/TBIA (item 3.1.1), os colmos foram cortados na metade do segundo internódio basal, imediatamente antes de serem imersos nos baldes, visando eliminar a cavitação no xilema. A metade basal 
desse internódio, normalmente descartada, foi aqui amostrada e submetida ao TBIA para se ter a \%VC em amostras não coloridas pela safranina O do MCVX. Estas amostras constituíram o tratamento sem safranina O denominado CONTROLE. As amostras extraídas da outra metade desse internódio haviam sido submetidas ao MCVX $\mathrm{e}$, como continham a solução vermelha corante à base de safranina $\mathrm{O}$ constituíram o tratamento COLORIDO (Figura 1a). Os cilindros amostrados nesses dois tratamentos foram acondicionados em placas plásticas separadas para evitar manchas nas membranas que foram processadas com amostras do tratamento CONTROLE. A partir daí, o processo de identificação e contagem de vasos colonizados seguiu como descrito no item 3.1.1.1.

Caso a safranina $O$ não interferisse marcadamente nas avaliações, a \%VC na metade do segundo internódio basal submetida ao processo conciliado MCVX/TBIA (COLORIDO) seria semelhante àquela observada nas amostras padrões (CONTROLE). Para avaliar o grau dessa semelhança, foram realizadas análises de regressão linear com intercepto fixo em zero e correlação entre a \%VC nos tratamentos CONTROLE e COLORIDO. Fazendo-se uma analogia com o estudo de validação de escalas diagramáticas para avaliar severidade de doenças, a precisão $\left(\mathbf{R}^{\mathbf{2}}\right)$ e acurácia (a) foram utilizadas como parâmetros para determinar a influência da safranina $O$ no TBIA. Precisão foi representada pelo coeficiente de determinação dos ajustes $\left(\mathbf{R}^{2}\right)$ e a acurácia pela inclinação (a) da reta de regressão linear com intercepto fixo em zero, conforme sugeriu Bernhard Hau ("Tropeninstitut, University of Giessen, West Germany") numa apresentação oral no "1979 International Workshop on Botanical Epidemiology" realizado na "Pennsylvania State University" (Campbel \& Madden, 1990). Valores máximos de precisão e acurácia são alcançados quando $\mathbf{R}^{\mathbf{2}}$ e a forem iguais a 1,00. A severidade de doença é superestimada quando a for maior que 1,00; caso contrário, ela é subestimada. Segundo Amorim (1995), uma estimativa é precisa quando é feita com rigor e refinamento e acurada, quando apresenta exatidão sem erros sistemáticos. Cabe relembrar, que incidência e severidade são os dois parâmetros freqüentemente utilizados para expressar intensidade de doenças. Incidência é a porcentagem (frequiência) de plantas doentes ou partes doentes da planta em uma 
amostra ou população. Severidade é a porcentagem de área ou volume de tecido coberto por sintomas. No caso do RS, incidência e severidade são expressas pela porcentagem de colmos infectados e pelo grau da colonização dos feixes vasculares do colmo (VC, $\% \mathrm{VC}, \mathrm{VNF}$ e $\% \mathrm{VNF}$ ).

\subsubsection{Repetibilidade dos resultados obtidos pelo método conciliado MCVX/TBIA}

Com o objetivo de se determinar a repetibilidade dos resultados obtidos pelo método conciliado MCVX/TBIA, duas secções transversais de $10 \mathrm{~mm}$ de diâmetro e $10 \mathrm{~mm}$ de altura (cilindro) foram amostradas no terceiro internódio basal de cada colmo amostrado, logo após a coloração dos vasos do xilema pelo MCVX (Figura la). Na primeira (SEÇÃO 1) e na segunda amostra (SECÇÃO 2), a \%VC e \%VNF foram quantificadas através do protocolo MCVX/TBIA (item 3.1.1.1). Fazendo-se um analogia ao estudo de validação de escalas diagramáticas (item 3.1.2), a quantidade de doença avaliada na SEÇÃO 1 e SECÇÃO 2 representaram a severidade real e estimada, respectivamente. Assim, através de regressão linear com intercepto fixo em zero entre severidade real e estimada, tanto para \% VC como \% VNF, determinou-se a precisão $\left(\mathbf{R}^{2}\right)$ e acurácia (a) com que a segunda avaliação (SECÇÃO 2 = estimada) estimava os resultados obtidos na primeira (SECÇÃO 1 = real).

\subsubsection{Tamanho da amostra para avaliar a severidade do RS em seções transversais de colmos de cana-de-açúcar}

Para se determinar o tamanho da amostra representativa da secção transversal do colmo de cana-de-açúcar, a extensão da colonização dos tecidos vasculares por $C$. $x$. subsp. $x y l i$ foi estudada em oito genótipos diferindo quanto ao grau de suscetibilidade ao RS. Para tanto, na coleção de genótipos do Programa de melhoramento genético da cana-de-açúcar de Canal Point, Flórida - EUA, foram amostrados 10 colmos de cada genótipo. Seguindo o protocolo MCVX/TBIA (item 
3.1.1.1), logo após a coloração do xilema, uma única secção transversal medindo $22 \mathrm{~mm}$ de diâmetro foi removida do terceiro internódio de cada colmo, correspondendo à amostra GRANDE (Figura lb). Para colmos finos, menores que $22 \mathrm{~mm}$, toda a seção transversal, sem casca, foi amostrada. No centro da amostra GRANDE, com o auxílio de vasadores de rolhas, foram demarcadas as amostras MÉDIA e PEQUENA que possuíam 16 e $10 \mathrm{~mm}$ de diâmetro, respectivamente. Como as secções transversais das amostras PEQUENA, MÉDIA e GRANDE eram circulares (área $=\pi \mathrm{r}^{2}$ ), suas áreas compreendiam $0,785,2,010$ e $3,799 \mathrm{~cm}^{2}$, respectivamente. O número total de feixes vasculares (TV) amostrados, a porcentagem de vasos colonizados (\%VC) e não funcionais $(\% \mathrm{VNF})$ foram quantificados para os três diferentes tamanhos de amostra. Análises de regressão linear e correlação entre a severidade do RS (\%VC e \%VNF) observada na amostra GRANDE e nas reduzidas (MÉDIA e PEQUENA) foram conduzidas para escolher o tamanho do diâmetro da secção transversal para representar o colmo todo. Da mesma forma, foi analisado o parâmetro TV.

\subsubsection{Parâmetro que melhor representa a severidade do RS em colmos de cana-de-açúcar}

De acordo com Amorim (1995), incidência é a porcentagem (frequência) de plantas doentes em uma amostra ou população, enquanto severidade é a porcentagem da área ou volume de tecido coberto por sintomas. Para o patossistema $C$. $x$. subsp. $x y l i$ cana-de-açúcar pode-se dizer que a porcentagem de colmos infectados representa a incidência, e o número de feixes vasculares afetados por colmo (VC), a severidade. Portanto, este último tende a ter melhor correlação com perdas e deve ser o parâmetro utilizado para classificar genótipos quanto ao nível de resistência à doença (Gillaspie \& Davis, 1992). No entanto, a porcentagem de vasos colonizados pela bactéria (\%VC) parece, à primeira vista, representar a severidade do RS melhor que a simples contagem do número de vasos afetados (VC), pois considera a variação do número total de vasos de cada genótipo. Para verificar a veracidade desta afirmação, foi conduzido um ensaio 
para estimar a correlação entre VC e \%VC. De maneira análoga, estudou-se a relação entre o número absoluto (VNF) e a porcentagem (\%VNF) de vasos não funcionais.

$\mathrm{Na}$ quarta soca da coleção de genótipos do programa de melhoramento genético da cana-de-açúcar de Canal Point ("USDA-ARS Sugarcane Field Station"), Flórida - EUA, foram escolhidos 19 genótipos com nove meses de idade e apresentando uma ampla gama de reação ao RS. Cada genótipo foi representado por 10 colmos, os quais foram submetidos ao protocolo MCVX/TBIA (item 3.1.1.1). Com os dados obtidos, foram conduzidas análises de regressão linear e correlação entre VC e $\%$ VC, e VNF e \%VNF. 
3.2 Efeitos da colonização de colmos de cana-de-açúcar por $C$. $x$. subsp. xyli na funcionalidade dos vasos do xilema de genótipos diferindo em suscetibilidade ao RS

\subsubsection{Padrão de colonização de feixes vasculares por $C$. $x$. subsp. xyli em seç̧ões transversais de colmos de cana-de-açúcar}

O método conciliado MCVX/TBIA (item 3.1.1) foi aplicado para determinar o padrão de colonização de feixes vasculares por $C$. $x$. subsp. xyli, em secções transversais de colmos de oito genótipos de cana-de-açúcar diferindo em suscetibilidade ao RS. Para tanto, nas mesmas amostras obtidas no item 3.1 .3 (secções tranversais de $22 \mathrm{~mm}$ de diâmetro e $10 \mathrm{~mm}$ de altura), com o auxílio de vazadores de rolhas, foram demarcados os feixes vasculares distribuídos no CENTRO, MEIO e PERIFERIA, ou seja, aqueles distanciados de zero a 10, 10 a 16 e 16 a $22 \mathrm{~mm}$ do ponto central do internódio (Figura lb). O número total de feixes vasculares (TV), vasos colonizados (VC) e entupidos (VNF) foram quantificados no CENTRO, MEIO e PERIFERIA dos internódios. Com os resultados obtidos, determinou-se a distribuição da bactéria e seus efeitos na secção transversal do colmo.

\subsubsection{Relação entre colonização e entupimento dos vasos do xilema de colmos de cana-de-açúcar por $C$. $x$. subsp. $x y l i$}

Num primeiro experimento, nove clones moderadamente resistentes foram selecionados de um teste de rotina do programa de melhoramento genético da cana-de-açúcar de Canal Point para identificação de genótipos resistentes ao RS que, em 1995, estava sendo conduzido em Belle Glade ("Everglades Research Area of the University of Florida - EUA") pelo Dr. J.C. Comstock ("USDA -ARS Sugarcane Field Station, Canal Point, FL”). Na instalação do campo, o material propagativo utilizado para o plantio foi inoculado imergindo-se os toletes de uma gema em suco extraído de colmos infectados da genótipo suscetível CP53-1 (Dean, 1983; Gillaspie et al., 1976; 
Koike et al., 1982) por 10 minutos. Após a inoculação, os toletes foram plantados em parcelas de $1,52 \mathrm{~m}$ (cinco pés) de comprimento, em 25 de janeiro de 1995, cada genótipo sendo representado por quatro repetições. Oito meses após o plantio, cinco colmos foram amostrados em cada parcela e submetidos ao protocolo MCVX/TBIA descrito no item 3.1.1.1.

Um segundo experimento incluindo 19 genótipos que tinha uma gama muito maior de reação ao RS foi conduzido na coleção de genótipos de Canal Point implantada em 9 de agosto de 1990. Como a coleção estava sendo conduzida sem medidas de controle do RS, as plantas estavam naturalmente infectadas por $C$. $x$. subsp. $x y l i$, sendo cada genótipo representado por uma única parcela constituída por um sulco de 1,82 m (seis pés) de comprimento. Em quarta soca, 10 colmos com nove meses de idade foram amostrados de cada parcela e submetidos ao protocolo MCVX/TBIA (item 3.1.1.1).

Para ambos os experimentos, análises de correlação e regressão linear foram utilizadas para determinar a relação entre a colonização dos feixes vasculares medida por VC e a sua influência na funcionalidade do xilema medida pelo número de VNF.

\subsection{Eficácia dos métodos MCVX e TBIA para identificação de genótipos de cana-de-açúcar resistentes ou tolerantes ao $\mathrm{RS}$}

O método conciliado MCVX/TBIA foi aplicado num terceiro experimento com o objetivo de comparar a eficácia do MCVX com a do TBIA quanto à capacidade de identificar genótipos de cana-de-açúcar resistentes ou tolerantes ao RS. O ensaio havia sido originalmente instalado em 1992 pelo Dr. M.P. Grisham ("USDA ARS Sugarcane Research Unit, Houma, LO"), e nos foi gentilmente cedido para o teste.

Segundo Dr. Grisham, o campo experimental foi delineado em blocos ao acaso com parcelas de cinco metros de comprimento, dois metros (três sulcos) de largura e replicadas quatro vezes para cada um dos 11 genótipos estudados. Os colmos para o plantio foram produzidos em um viveiro, no ano anterior à instalação do 
experimento, para que as mudas pudessem crescer no mesmo tipo de solo e tivessem a mesma idade. Para obter plantas doentes, toletes de uma gema de cada genótipo foram submergidos por 10 minutos em suco extraído de colmos de canas maduras infectadas pela bactéria do RS. Os toletes inoculados foram plantados em casa de vegetação, onde permaneceram por aproximadamente cinco meses, antes de serem transplantadas para o viveiro. Plantas sadias foram conseguidas de colmos não inoculados e tratados em água a $50^{\circ} \mathrm{C}$ por duas horas (Benda $\&$ Ricaud, 1977) os quais foram plantados diretamente no viveiro. Amostras dos tratamentos sadios e doentes de cada genótipo foram coletadas próximo à colheita das mudas e o número total de vasos colonizados (VC) foram identificados pelo TBIA. VC foram observados entre todas as amostras de plantas do tratamento inoculado, excetuando aquelas representando o genótipo resistente CP52-68, mas não em plantas do tratamento controle. Desta forma, foi assegurada a existência dos tratamentos RS e controle sadio no campo experimental.

Os colmos produzidos em cada parcela da cana-planta e primeira soca foram cortados com uma colheitadeira mecânica em 8 de novembro de 1993 e 31 de outubro de 1994, respectivamente. A base da colheitadeira era descontaminada com uma solução $15 \%$ de substância fenólica (Lysol cleaner, Lehn and Fink Products Division of Sterling Drug, Inc., Montvale, NJ), antes de mudar a máquina de uma parcela doente para uma controle. Essas medidas foram tomadas pela equipe do Dr. Grisham, para evitar contaminação das parcelas do tratamento controle sadio.

\subsubsection{Identificação de genótipos de cana-de-açúcar resistentes ao $\mathbf{R S}$}

Em setembro de 1995, na segunda soca do terceiro experimento (campo experimental do Dr. Grisham citado item 3.3), três repetições de cada tratamento foram utilizadas para determinar o nível de resistência ao RS de cada genótipo. com base nos parâmetros \%VC e \%VNF determinados pelo TBIA e MCVX, respectivamente. Para tanto, 10 colmos foram amostrados, de maneira casualizada, no sulco central de cada parcela, e submetidos ao processo conciliado MCVX/TBIA. As médias foram 
agrupadas pelo método de grupamento univariado proposto por Scott-Knott (1974), ajudando a classificar os genótipos em diferentes níveis de resistência ao RS. A performance desse método foi comparada com a do teste de variação múltipla proposto por Duncan (1955).

\subsubsection{Identificação de genótipos de cana-de-açúcar tolerantes ao RS}

Segundo Dr. Grisham, nove meses após o plantio, a cana-planta das parcelas do terceiro experimento haviam sido colhidas, queimadas para remover folhas mortas, e pesadas. Análises estatísticas com o parâmetro toneladas de cana por acre (tC/acre) foram realizadas para determinar os efeitos do RS na produtividade dos genótipos testados. Estes resultados foram comparados com aqueles obtidos no item 3.3.1, para determinar o nível de tolerância de cada genótipo. Genótipos que suportaram a colonização dos vasos sem diferença significativa entre produção de parcelas sadias e doentes foram classificadas como tolerantes ao RS. 


\section{RESULTADOS E DISCUSSÃO}

4.1 Padronização de método para avaliar a colonização de colmos de canade-açúcar por $C$. $x$. subsp. xyli e o respectivo efeito na funcionalidade dos vasos do xilema

\subsubsection{Método conciliado MCVX/TBIA}

\subsubsection{Protocolo MCVX/TBIA}

Foi perfeitamente possível conciliar MCVX e TBIA para estimar a colonização de feixes vasculares por $C$. $x$. subsp. xyli e os efeitos decorrentes da presença da bactéria na funcionalidade dos vasos do xilema, numa mesma amostra de colmos de cana-de-açúcar. MCVX coloriu os vasos do xilema funcionais mas não os não funcionais (VNF), detectando os efeitos do RS no transporte de água pela planta (Figura 2). Por outro lado, TBIA coloriu os vasos colonizados por C. $x$. subsp. $x y l i$ (VC), dando informação sobre a presença do patógeno no xilema (Figura 3).

Tanto a \%VNF como a \%VC obtidas pelo processo conciliado MCVX/TBIA confirmaram os níveis de severidade alto, médio e baixo esperados nos genótipos resistente (Comstock et al., 1996ab), suscetível (Douglas, 1981) e altamente suscetível (Comstock et al., 1996b): CP72-2086 (\%VNF = 6,42; \%VC = 7,55), CB41$76(\% \mathrm{VNF}=13,17 ; \% \mathrm{VC}=29,68)$ e $\mathrm{CP} 53-1(\% \mathrm{VNF}=40,19 ; \% \mathrm{VC}=69,12)$, respectivamente (Tabela 1). Como a \%VNF foi menor que a \%VC para os três genótipos estudados, o fluxo de água não foi completamente evitado em todos os vasos colonizados, sendo encontrados, na média, 19,93\% de VNF apesar dos 35,45\% colonizados pela bactéria do RS.

Presumivelmente, o número de VNF foi provavelmente subestimado devido à idade dos colmos no momento da amostragem: oito e nove meses de idade. A idade dos colmos e o período após a incubação da bactéria influenciou a intensidade de RS (Davis et al., 1988a; Harrison \& Davis, 1988; Gillaspie et al., 1976; Iamauti \& 
Tokeshi, 1994) e a equivalência entre o MCVX e o método da observação de $C$. $x$. subsp. xyli em microscópio de contraste de fase: "à medida que o dano no transporte de fluidos se intensifica, existe maior concordância entre os métodos" (Iamauti \& Tokeshi, 1994). Então, uma maior proporção de VNF seria esperada se colmos mais velhos fossem amostrados. Por este motivo, secções de tecidos foram retiradas do terceiro internódio basal, numa tentativa de minimizar a influência da idade dos colmos no MCVX. Isto consiste numa modificação do processo de amostragem do MCVX utilizado nos trabalhos de Chagas (1986), Chagas \& Tokeshi (1988; 1994ab), Iamauti (1990) e Iamauti \& Tokeshi (1994). Nesses trabalhos os três nós basais eram descartados para eliminar o efeito da cavitação nos vasos do xilema. Consequentemente, a \%VNF era estimada no quinto internódio basal o qual é menos maduro e menos infectado que o terceiro (Harrison \& Davis, 1988). No presente estudo, as amostras foram retiradas do terceiro internódio basal e a cavitação nos vasos do xilema prevenida colocando-se os colmos dentro dos baldes com a solução corante não mais que cinco minutos após a colheita, o que permitiu o descarte de apenas o primeiro nó basal.

Diante do exposto, a densidade populacional de $C$. $x$. subsp. $x y l i$ nos vasos colonizados, porém funcionais, parece não ter sido suficiente para evitar completamente o transporte de água pelo fluxo transpiratório da planta. Sabe-se que a prevenção no transporte de água é a principal atividade fisiológica da planta afetada pela bactéria do RS que conduz a danos em produção (Hughes \& Steindl, 1955; Steindl, 1961). A prevenção ocorre quando as células de $C$. $x$. subsp. xyli agem como barreiras físicas ao transporte de água pelos xilemas ou quando há produção de geis (Kao \& Damann, 1980) e gomas (Steindl, 1961; Weaver et al., 1977) que obstruem estes vasos em resposta à infecção e colonização (Steindl, 1961). Portanto, embora a identificação do responsável pela produção destas substâncias, hospedeiro ou patógeno, permaneça como um desafio para a fisiologia do parasitismo, o método conciliado MCVX/TBIA consiste numa ferramenta útil para estudar os efeitos da bactéria do RS no transporte de água de diferentes genótipos de cana-de-açúcar, podendo contribuir para o melhor entendimento dos mecanimos de resistência ou tolerância ao RS. 


\subsubsection{Influência da safranina $O$ na detecção dos vasos colonizados pelo método conciliado MCVX/TBIA}

A Figura 4 ilustra o gráfico construído plotando-se a \%VC observada nas membranas manchadas com safranina O (tratamento COLORIDO) em função da \%VC nas membranas padrões processadas com amostras de internódios que não haviam sido submetidos ao MCVX (tratamento CONTROLE). A regressão linear entre severidade nos tratamentos CONTROLE e COLORIDO indicou altos valores de precisão $\left(\mathbf{R}^{2}=\right.$ $0,931)$ e acurácia $(\mathbf{a}=0,882)$. Apesar de alguns feixes vasculares não serem detectados nas membranas manchadas pelo corante $(\mathbf{a}<1,00)$, alta correlação positiva $(\mathbf{r}=0,966)$ foi observada entre \%VC estimada nos tratamentos CONTROLE e COLORIDO. As manchas vermelhas causadas por safranina $\mathrm{O}$ foram, em grande parte, removidas das membranas de nitrocelulose quando estas foram tratadas com a solução $1,5 \%$ de hipoclorito de sódio, na penúltima etapa do TBIA. Assim, com auxílio do estereomicroscópio, foi possível observar nas membranas a nítida coloração azul dos VC para melhor identificação e contagem dos mesmos. Portanto, a substância vermelha safranina $\mathrm{O}$ não representa um problema ao processo serológico do TBIA.

\subsubsection{Repetibilidade dos resultados obtidos pelo método conciliado MCVX/TBIA}

As regressões lineares entre severidade real e estimada. os respectivos coeficientes de determinação $\left(\mathbf{R}^{2}\right)$ dos ajustes e inclinação da reta (a) estão apresentadas nos gráficos da Figura 5. Estes gráficos foram construídos plotando-se a severidade (\%VC e \%VNF) estimada (SECÇÃO 2) em função da real (SECÇÃO 1). A \%VNF na SECÇÃO 2 estimou a \%VNF na SECÇÃO 1 com excelente precisão $\left(R^{2}=0,98\right)$ e acurácia $(\mathrm{a}=1,007)$. Da mesma forma, excelente precisão $\left(\mathrm{R}^{2}=0,921\right)$ e acurácia $(\mathrm{a}=$ $1,009)$ foram obtidos quando a doença foi quantificada pela \%VC. 
Diante do exposto, quando duas amostras foram retiradas do mesmo internódio, o método conciliado MCVX/TBIA proporcionou praticamente os mesmos valores de severidade do RS, independentemente se a doença foi representada pela $\%$ VNF ou \%VC. Consequentemente, o método consiste numa excelente ferramenta para avaliar a resistência de genótipos de cana-de-açúcar ao RS, no que diz respeito à confiabilidade e repetibilidade dos resultados.

\subsubsection{Tamanho da amostra para avaliar a severidade do RS em seções transversais de colmos de cana-de-açúcar}

Diferenças entre genótipos foram encontradas na porcentagem de vasos colonizados por $C$. $x$. subsp. xyli e obstruídos pela ação desta bactéria no interior do hospedeiro, para as diferentes amostras avaliadas (Figura 6).

Análises de regressão linear entre a severidade do RS de amostras reduzidas (PEQUENA e MÉDIA) e GRANDE revelaram altos coeficientes de correlação (r), independentemente se a doença foi avaliada pelo TBIA ou MCVX. No caso da avaliação da colonização dos vasos (\%VC), r foi igual a 0,998 e 0,990 quando a amostra GRANDE foi relacionada com a MÉDIA e PEQUENA, respectivamete (Figura 7). Da mesma forma, $\mathbf{r}$ foi igual a 0,999 para correlação entre \%VNF na amostra MÉDIA e GRANDE e 0,988 entre PEQUENA e GRANDE (Figura 8). Isto indica que, mesmo reduzindo ao máximo $(\phi=10 \mathrm{~mm})$ o tamanho da amostra, houve alta correlação entre a severidade estimada e a severidade a real (amostra GRANDE) do colmo.

Na média dos oito genótipos estudados, a avaliação da severidade do RS na secção transversal PEQUENA (área de $0,785 \mathrm{~cm}^{2}$ ) extraída do centro do terceiro intemódio proporcionou uma superestimativa da quantidade real de doença observada na amostra GRANDE (área de 3,799 $\mathrm{cm}^{2}$ ). Para \%VC, a estimativa foi praticamente o dobro da severidade real, ou seja, 29,77 e 14,22\% para PEQUENA e GRANDE, respectivamente (Tabela 2). O mesmo efeito, porém mais intenso, foi observado para $\%$ VNF que teve a severidade no centro $(9,51 \%)$ aumentada em 2,52 vezes em relação à severidade na amostra GRANDE (3,78\%). Isto ocorre porque, aumentando o tamanho 
da amostra, o número total de vasos aumentava muito mais intensamente que o número de vasos colonizados (Figura 9), diminuindo a relação entre vasos doentes e sadios (Figura 6). Tal evento é explicável pois os feixes vasculares de colmos de cana-deaçúcar encontram-se distribuídos pelo tecido parenquimatoso, sendo mais numerosos nas proximidades da epiderme (Artschwager, 1925; Harrison \& Davis, 1988) e a colonização destes feixes vasculares por $C$. $x$. subsp. $x y l i$ é mais abundante nos tecidos do centro da secção transversal do internódio (Harrison \& Davis, 1988). No presente estudo, considerando os oito genótipos estudados, foram encontrados 39,94, 31,65 e 17,64 vasos colonizados nas amostras GRANDE, MÉDIA E PEQUENA, respectivamente, enquanto que os correspondentes valores de total de vasos (TV) foram iguais a $312,68,166,37$ e 60,49 . A alta correlação positiva $(\mathbf{r}=0,914)$ entre o número de vasos na amostra PEQUENA e GRANDE (Figura 10) indica que o descarte dos vasos próximos à periferia da seç̧ão transversal do internódio pouco interfere na diagnose, no que se refere à representatividade de uma amostra.

Os genótipos L60-25 e CB49-260 continham as menores quantidades de vasos amostrados no colmo, 277,60 e 278,44, respectivamente, contrastando com o valor de 361,90 vasos apresentado pela CP72-356 e 373,00 pela CP70-321 (Figura 11). Quando apenas o centro do internódio foi amostrado (secção transversal de $10 \mathrm{~mm}$ ), também houve variação quanto ao número de vasos amostrados nos diferentes genótipos estudados (Figura 12). Os genótipos CP53-1 e CP72-356 apresentaram o menor $(45,30)$ e o maior $(92,00)$ número de feixes vasculares na região central do internódio. Por este motivo, surge a dúvida quanto à validade de se avaliar a severidade do RS com base no número absoluto de vasos colonizados (VC), quando a intenção é comparar genótipos (Comstock et al., 1996ab; Miller et al., 1995). Hipoteticamente, imaginando-se dois genótipos com o mesmo número de vasos infectados, as perdas causadas pelo RS seriam maiores para aquele com menor número de vasos sadios, considerando níveis de tolerância semelhantes. Surge então a necessidade de se determinar a relação entre a severidade de RS medida pelo número absoluto de $\mathrm{VC}$ e pela porcentagem de colonização dos vasos (\%VC). 
Apesar de superestimar a severidade do RS em colmos de cana-deaçúcar, uma pequena amostra de $10 \mathrm{~mm}$ de diâmetro no centro do terceiro internódio basal (Comstock et al., 1996ab; Miller et al., 1995) pode ser utilizada para determinar a resistência de genótipos. Neste caso, apenas $0,785 \mathrm{~cm}^{2}$ de membrana é analizada pelo TBIA, valor este muito menor que os $3,799 \mathrm{~cm}^{2}$ da amostra GRANDE. Portanto, o uso da amostra PEQUENA permite uma grande economia de tempo e de reagentes, reduzindo os custos da avaliação da severidade do RS, vislumbrando o uso do TBIA e/ou MCVX em estudos para determinar os efeitos de medidas de controle e de condições ambientais sobre o desenvolvimento da doença e respectivas perdas, além de testes para identificar a resistência de genótipos.

\subsubsection{Parâmetro que melhor representa a severidade do RS em amostras de colmos de cana-de-açúcar}

As equações das retas de regressão linear entre número absoluto de vasos colonizados (VC), porcentagem de vasos colonizados (\%VC) e as respectivas taxas de correlação (r) estão representadas nos gráficos das Figuras 13 e 14. Estes gráficos foram construídos plotando-se VC em função da \%VC, considerando a média de 10 amostras para cada genótipo.

$\mathrm{Na}$ secção transversal amostrada $\left(0,785 \mathrm{~cm}^{2}\right)$, quando a severidade variou desde zero até $94,62 \%$ de vasos colonizados por $C$. $x$. subsp. $x y l i$, ou seja, para ampla gama de reação ao RS (Figura 13), os resultados obtidos pelo VC foram bastante semelhantes àqueles proporcionados pela $\% \mathrm{VC}(\mathbf{r}=0,925)$. Consequentemente, a simples contagem do número absoluto de vasos colonizados pode ser utilizada em testes para classificar genótipos de cana-de-açúcar nos três níveis básicos de resistência ao RS: resistentes, intermediários e suscetíveis. Porém, quando o genótipo altamente suscetível CP74-383 (\%VC = 94,62) e os resistentes CB40-13, CP68-1067, CP71-1086 e CP72-2086 (\%VC = zero) foram excluídos da análise (Figura 14), a correlação entre VC e \%VC diminuiu $(\mathbf{r}=0,775)$, comprometendo a classificação correta dos genótipos. Como exemplo, o genótipo CP63-588 apresentou VC menor $(18,8)$ que o CP79-318 
$(25,1)$ apesar de o primeiro ter \%VC muito maior que o segundo $(54,41$ e 27,21 , respectivamente). $\mathrm{O}$ fator determinante desta inversão, já discutida no item 4.1.2, consiste na diferença entre genótipos quanto ao número de vasos amostrados (TV), ou seja, o maior valor de TV $(92,6)$ foi observado na CP79-318, enquanto o menor $(33,9)$ na CP63-588 (Tabela 3).

De maneira similar, a L62-92 (TV $=56,4)$ apresentou VC semelhante $(29,4)$ mas \%VC muito maior $(52,27)$ que a CP79-318. Considerando que a primeira tem apresentado danos significativos devido à ocorrência do RS (Grisham, 1994; Koike et al., 1982 ), enquanto a segunda tem mostrado relativa tolerância (Grisham, 1994), não se pode esquecer o possível efeito da compensação da absorção de água e sais mineirais pelo excesso de feixes vasculares sadios. Fato muito semelhante a este já foi demonstrado para o Carvão da cana-de-açúcar (Ustilago scitaminea Syd.) cuja tolerância foi associada à compensação da produção de plantas doentes pelo excesso de perfilhamento dos genótipos NA56-79 (Giglioti et al., 1991, Tokeshi, 1986; Tokeshi et al., 1987) e RB785148 (Giglioti \& Tokeshi, 1993). Portanto, o VC não deve ser utilizado para classificação detalhada da reação de genótipos de cana-de-açúcar, principalmente se avaliações de danos e perdas estiverem envolvidas.

4.2 Efeitos da colonização de colmos de cana-de-açúcar por $C$. $x$. subsp. xyli na funcionalidade dos vasos do xilema de genótipos diferindo em suscetibilidade ao RS

\subsubsection{Padrão de colonização de feixes vasculares por $C$. $x$. subsp. $x y l i$ em seç̧ões transversais de colmos de cana-de-açúcar}

Diferenças entre genótipos foram encontradas no número total de feixes vasculares distribuídos no CENTRO, MEIO e PERIFERIA dos internódios e na porcentagem destes vasos contendo $C$. $x$. subsp. $x y l i$ ou obstruídos pela ação da bactéria no interior do hospedeiro. 
Secções transversais de internódios mostraram um arranjarmento de feixes vasculares parecido com aquele descrito por Artschwager (1925) e também observado por Harrison \& Davis (1988) para a cana-de-açúcar. Os feixes estavam distribuídos pelo tecido parenquimatoso, sendo mais numerosos nas proximidades da periferia dos internódios (Figura 15). Na média dos oitos genótipos, foram avaliados 312,68 vasos na amostragem total (22 $\mathrm{mm}$ ), estando 19,35\%, 33,86\% e 46,79\% distribuídos, respectivamente, no CENTRO, MEIO e PERIFERIA da secção transversal do internódio (Figura 16).

O método de diagnose direta TBIA detectou VC espalhados por toda a seç̧ão transversal do internódio. Porém, a freqüência de vasos colonizados por $C$. $x$. subsp. $x y y l i$, que era alta no centro de secções transversais de colmos de cana-de-açúcar, diminuía significativamente nos tecidos adjacentes à epiderme. Na média dos oito genótipos estudados, foram observados $29,77 \%, 15,49 \%$ e 6,69\% de VC no CENTRO, MEIO e PERIFERIA dos internódios, respectivamente (Figura 17). De maneira indireta, MCVX demonstrou o mesmo padrão de colonização (\%VNF = 9,51, 3,67 e 1,25 para CENTRO, MEIO e PERIFERIA, respectivamente), havendo alta correlação positiva ( $\mathbf{r}$ $=0,995)$ entre \%VC e \%VNF nos tecidos do CENTRO, MEIO e PERIFERIA dos internódios (Figura 18). MCVX detectou 9,51\%, 3,67\% e 1,25\% de vasos obstruídos pela ação de $C$. $x$. subsp. $x y l i$ no CENTRO, MEIO e PERIFERIA, respectivamente. Portanto, a exemplo do observado no item 4.1.1.1, nem todos os vasos infectados estavam obstruídos pela bactéria. Considerando todos os vasos do terceiro internódio basal, dos $32,09 \%$ de VC apenas $44,97 \%$ estavam entupidos, ou seja, a \%VNF foi igual a 14,43 .

O mesmo padrão de colonização vascular persistiu em todos os oito genótipos estudados em detalhe (Figura 19), estando os resultados em acordo com aqueles obtidos por Harrison \& Davis (1988). Estes autores, analisando três genótipos diferindo em suscetibilidade ao RS, sugeriram que o padrão de colonização de tecidos vasculares de cana-de-açúcar deva estar correlacionado com a maturidade dos tecidos do colmo. Segundo eles, geralmente, vasos infectados são mais numerosos e a 
população do patógeno maior em tecidos do centro dos internódios mais maduros da base do colmo, diminuindo nas proximidades da epiderme.

Poucos vasos infectados foram encontrados no CENTRO, MEIO e PERIFERIA das secções transversais do tecido do terceiro internódio dos genótipos L60-25 e CP70-1133, relativamente mais resistentes (Gillaspie et al., 1976; Harrison \& Davis, 1988). Em contraste, genótipos suscetíveis como a CP53-1 (Dean, 1983; Gillaspie et al., 1976; Koike et al., 1982) e CP74-383 (Grisham, 1991;1994) apresentaram altos índices de colonização dos vasos (Figura 19). Embora as bases responsáveis para a diferença de colonização de genótipos por $C$. $x$. subsp. xyli não tenha sido objetivo do presente estudo, pode-se supor que características intrínsecas da anatomia vascular na região nodal dos colmos podem estar envolvidas de maneira a restringir a distribuição do patógeno ao longo do xilema (Teakle et al., 1975b; 1978). Teakle et al. (1975b) demonstraram que, de 11 genótipos examinados, o número de feixes vasculares enegrecidos, após a passagem de corante da Índia (carvão coloidal) através da região nodal de colmos sadios de cana-de-açúcar, foi negativamente correlacionado com a resistência ao RS. Similarmente, a taxa de movimento de água através da região nodal de colmos sadios também apresentou correlação negativa com resistência ao RS (Teakle et al., 1975a; 1978). Tanto a redução no fluxo de água como a limitação na passagem de partículas do corante dentro do xilema foram atribuídas a uma maior ramificação dos vasos do metaxilema na região nodal, resultando em menos vasos que passaram diretamente através dos nós, ou seja, em genótipos resistentes (Teakle et al., 1978).

O presente estudo indica que a resistência de genótipos de cana-deaçúcar ao RS está associada com baixa taxa de colonização de colmos por $C$. $x$. subsp. $x y l i$, confirmando resultados prévios (Davis et al., 1994; Harrison \& Davis, 1988, Miller et al., 1995). A colonização de tecidos vasculares em secções transversais de colmos do genótipo CP70-1133, o menos suscetível dentre os três estudados, era significantemente menor que nos genótipos CP72-1210 e CP44-101; em contrapartida, a colonização foi mais abundante no genótipo CP72-1210, o mais suscetível. É interessante observar que a intensidade de colonização, medida pelo número de vasos colonizados no terceiro 
internódio basal de 10 genótipos, foi correlacionada positivamente $(\mathbf{r}=0,95)$ com a densidade populacional da bactéria em extratos vasculares destes tecidos (Harrison \& Davis, 1988). Além disso, a resistência à colonização foi também relacionada $(\mathbf{r}=0,93)$ com a disseminação do RS no campo, quando seis genótipos foram estudados (Comstock et al., 1996b). Tanto a densidade populacional (Davis et al., 1988b; Gillaspie et al., 1976; Koike et al., 1982) como a disseminação do RS no campo (Damann, 1992) apresentaram correlação direta com a suscetibilidade ao RS. Baseados nesses resultados, na alta herdabilidade da resistência de cana-de-açúcar ao RS (Miller et al., 1995) e na significativa relação $(\mathbf{r}=0,51$ a 0,84$)$ entre o número de VC e danos na produção (Davis et al., 1994), a intensidade da colonização medida pelo número de VC está sendo utilizada com sucesso como parâmetro para selecionar genótipos resistentes ao RS no Estado da Flórida (Comstock et al., 1996a). Portanto, como a \%VNF revelou indiretamente o mesmo padrão de colonização que a \%VC (Figuras $18 \mathrm{e}$ 19), ao medir os efeitos da presença de $C$. $x$. subsp. $x y l i$ na funcionalidade dos vasos do xilema, o método de diagnose MCVX pode ser uma alternativa àqueles que não dispõem dos equipamentos e reagentes requeridos pelo TBIA para quantificar a severidade do RS em colmos de cana-de-açúcar.

\subsubsection{Relação entre colonização e entupimento dos vasos do xilema} de colmos de cana-de-açúcar por $C$. $x$. subsp. xyli

O método conciliado MCVX/TBIA permitiu o estudo da reação de genótipos de cana-de-açúcar ao RS, com base na colonização dos colmos por $C$. $x$. subsp. $x y l i$ (VC) e seus respectivos efeitos (VNF) na funcionalidade dos vasos do xilema.

No primeiro experimento, restrita colonização de tecidos vasculares (VC) foi encontrada em seç̧ões transversais de colmos dos genótipos CP92-1238 (VC = 0), CP92-1980 (VC = 0), CP92-1062 (VC = 0,25), CP92-1150 (VC = 0,40), CP92-1880 $(\mathrm{VC}=0,40)$ e CP92-1883 ( $\mathrm{VC}=1,40)$, os mais resistentes dentre os nove estudados (Tabela 4). Para os genótipos que se posicionaram medianamente, CP92-1924 e CP92- 
1914, o número de VC foi igual a 3,10 e 5,60, respectivamente. Em contrapartida, VC foi igual a 11,30 para o genótipo menos resistente CP92-2246. Quando a severidade do RS foi avaliada pelo número de vasos não funcionais (VNF), a classificação dos genótipos no grupo dos mais resistentes, medianos e menos resistentes manteve a mesma ordem indicada pelo VC. O genótipo CP92-1914, que suportou a colonização mais intensa, também apresentou o maior valor de $\operatorname{VNF}(9,20)$; por outro lado, os mais resistentes CP92-1980 e CP92-1238 apresentaram VNF igual a 0,40 e 0,80, respectivamente, sendo estes os menores valores encontrados.

Análises de regressão com os valores médios de severidade do RS para cada um dos nove genótipos estudados no primeiro experimento revelaram alta correlação positiva $(\mathbf{r}=0,987)$ entre a média do número de VC e os correspondentes VNF (Figura 20). Portanto, nas condições deste ensaio, o entupimento dos vasos estava estreitamente relacionado com a presença de $C . x$. subsp. $x y l i$ nos vasos. Esta relação entre VC e VNF para genótipos moderadamente resistentes sugere que o MCVX, conduzido de acordo com as condições ambientais exigidas pelo método (Chagas \& Tokeshi, 1994b), permite a diagnose indireta da presença da bactéria do RS nos vasos, em casos de baixa severidade de doença. Porém, no segundo experimento, usando 19 genótipos que tinham uma gama muito maior de resistência ao RS, uma correlação positiva menor $(\mathbf{r}=0,40)$ foi obtida (Figura 21).

A razão primária para a menor correlação obtida no segundo experimento foi que três genótipos, CP70-321, CP79-318 e L62-96 tinham acima de 10 vezes mais VC que VNF (Figura 22). Nestes genótipos, o patógeno estava presente; contudo, o transporte de água não foi completamente evitado nos vasos colonizados. Tal comportamento, sugere que, para estes genótipos, a densidade populacional de $C$. $x$. subsp. xyli não foi suficiente para atuar como barreira física ao transporte de água pelo xilema nem para induzir a oclusão dos vasos do metaxilema pela produção de geis (Kao \& Damann, 1980) e gomas (Steindl, 1961; Weaver et al., 1977). Além disso, não se pode descartar a hipótese de que o movimento da solução corante de um entrenó para outro tenha sido favorecido nos genótipos CP70-321, CP79-318 e L62-96 devido, presumivelmente, à possível menor ramificação dos feixes vasculares na região nodal. 
A hipótese da correlação entre anatomia vascular, movimento de água pela região nodal e resistência ao RS foi testada por Teakle et al. (1975b;1978). Genótipos suscetíveis que possuíam fluxo de água acelerado também apresentavam menor ramificação dos vasos do metaxilema na região nodal de colmos sadios, se comparados aos genótipos resistentes (Teakle et al., 1978). Naquele estudo o genótipo resistente H60-6909 e os tolerantes CP29-116 e Q95 tinham 80 a 100\% de seus vasos com intensa ramificação; contrariamente, para os suscetíveis Q80, Q28 e Q89, os valores foram apenas 20, 30 e $70 \%$, respectivamente.

Os mecanismos fisiológicos que determinam o bom funcionamento dos vasos do xilema mesmo quando estes são colonizados por $C$. $x$. subsp. $x y l i$ podem estar, pelo menos à primeira vista, relacionados com a tolerância de genótipos de cana-deaçúcar ao RS, pois o transporte de água é conhecido como o principal processo fisiológico afetado pela bactéria do RS que induz a danos na produção de cana-deaçúcar (Steindl, 1961; Gillaspie \& Teakle, 1989). Em suporte a esta hipótese, o genótipo CP79-318, com poucos vasos entupidos apesar de intensa colonização (Figura 22 ) tem se mostrado tolerante ao RS (Grisham, 1994). Além disso, análises de regressão linear entre a severidade obtida no segundo experimento e dados históricos de danos causados pela doença (Tabela 5) indicaram que o número de VNF está melhor correlacionado com danos em produção $(r=0,742)$ que o de VC $(r=0.514)$, quando quatorze genótipos foram analizados (Figura 23). Portanto, seria muito interessante o confronto do método conciliado MCVX/TBIA com dados de produção (YDT) para verificar se poucos vasos não funcionais apesar de intensa colonização dos mesmos poderia indicar tolerância ao RS.

Embora alguns genótipos suscetíveis suportem a colonização da bactéria sem contudo terem a funcionalidade dos vasos do xilema afetada significativamente, o método MCVX de diagnose indireta mostra-se como uma alternativa àqueles que não dispõem dos equipamentos e reagentes requeridos pelo TBIA para a seleção de genótipos de cana-de-açúcar resistentes ao RS. Esta afirmativa se baseia no fato de que o dado de número de vasos funcionais de colmos de cana-de-açúcar inoculados com caldo bruto de plantas infectadas pelo RS apresentou boa correlação com a diferença de 
vazão de água entre colmos sadios e doentes (Chagas \& Tokeshi, 1994b; Cruz, 1983; Davis \& Harrison, 1987; Valarini, 1978), além de classificar genótipos em níveis de resistência semelhantes àqueles determinados através de comparação da produção (Matsuoka, 1980). Esses métodos identificaram os genótipos CB41-76 e CB47-355 como suscetível e resistente, respectivamente.

\subsection{Eficácia dos métodos MCVX e TBIA para identificação de genótipos de cana-de-açúcar resistentes ou tolerantes ao RS}

\subsubsection{Identificação de genótipos de cana-de-açúcar resistentes ao RS}

A descontaminação das lâminas da colheitadeira mecânica com solução fenólica 15\%, antes da colheita de parcelas sadias do tratamento controle, foi eficiente para evitar qualquer infeção pela bactéria e, consequentemente, nenhum VC foi observado em tais parcelas (Tabela 6). No entanto, $0,20 \%$ a $4,89 \%$ de VNF foram observados nos tratamentos controle, consistindo em falsos positivos da diagnose pelo MCVX. Colmos danificados fisicamente ou por insetos (Chagas \& Tokeshi, 1994b) e sintomas de Escaldadura-das-folhas (E. A. Giglioti \& J. C. Comstock, resultados preliminares não publicados) causados pela bactéria Xanthomonas albilineans poderiam ser os determinantes da frequência de falsos positivos. Presumivelmente, no presente estudo, Escaldadura-das-folhas, causando desintegração das paredes do xilema (Cruz, 1983), além de diminuição na área transpirante pela morte de tecidos foliares, pode ter afetado o fluxo transpiratório, sendo um importante fator para tais falsos positivos, pois a doença foi comumente observada no campo experimental.

Para cada genótipo, a média de porcentagem de vasos não funcionais observada no tratamento controle sadio (\%VNF-TT), ou seja, aquele que havia sido instalados com mudas tratadas termicamente (TT) foi subtraída daquela observada no tratamento inoculado (\%VNF-RS) para eliminar falsos positivos da diagnose pelo MCVX. Análises de regressão linear revelaram alta correlação positiva $(\mathbf{r}=0,991)$ entre os resultados do MCVX com (\%VNF-RS) e sem (\%VNF-RS-TT) falsos positivos 
(Figura 24). Portanto, contrastando com recomendações prévias (Iamauti, 1990; Chagas, 1996; Chagas \& Tokeshi, 1996), conclui-se que parcelas controle com plantas sadias para eliminar tal evento não são necessárias para selecionar genótipos de cana-de-açúcar resistentes ao RS. Isto implica numa significativa redução nos custos desta tarefa, visto que apenas metade da área e trabalho utilizados no presente estudo seriam suficientes para o sucesso do MCVX.

As análises de variância para \%VNF e \%VC evidenciaram diferenças significativas entre genótipos, sendo perfeitamente possível agrupá-los quanto ao nível de resistência ao RS (Tabela 6), através da separação das médias pelos métodos de análise de agrupamento (Scott \& Knott, 1974). Assim, a colocação de cada genótipo nos diferentes grupos foi relativa à posição dos demais, sendo a resistência ao RS determinada quantitativamente como um caráter típico da resistência horizontal (Vanderplank, 1984). Este tipo de análise pode ser muito interessante, pois a cana-deaçúcar, por ser uma planta polifilética e de propagação vegetativa, desenvolveu naturalmente, ao longo de sua evolução, a resistência horizontal para a maioria de suas doenças (Matsuoka, 1993; Tokeshi, 1983). A resistência durável é de capital importância estratégica para a segurança de uma cultura monoclonal, extensiva e com sobreposição de cultivos (Robinson, 1987), como é praticada a agricultura canavieira.

A comparação entre o método de análise de agrupamento de Scott-Knott e teste de comparação múltipla (Duncan, 1955) indicou que o primeiro teve a vantagem de classificar os genótipos em grupos discretos, ou seja, sem sobreposição, o que é sempre desejado pelos fitopatologistas e/ou melhoristas, pois elimina qualquer efeito subjetivo, no momento da separação dos grupos (Tabela 7). Portanto, o método de Scott-Knott se adaptou muito bem ao tipo de análise requerido pelo presente estudo, sendo um método eficaz para agrupar genótipos de cana-de-açúcar quanto ao nível de resistência à colonização (\%VC) ou ao entupimento dos vasos do xilema por $C$. $x$. subsp. xyli. Resultados semelhantes, porém fora do campo da fitopatologia, foram obtidos quando estes dois métodos de análises estatísticas foram aplicados a quatro conjuntos de dados: (i) teste de produção de grãos por sete genótipos de cevada; (ii) produção de tubérculos por sete genótipos de batata; (iii) produção de 28 genótipos de 
algodão; e (iv) avaliação do conteúdo de nitrogênio em plantas de Trifolium pratense L. inoculadas com seis diferentes culturas de Rhizobium (Gates \& Bilbro, 1978). Estes autores demostraram que quanto menor a variância das médias dos tratamentos, maior a similaridade na separação dos grupos pelos respectivos métodos. Contudo, em contraste ao processo de Duncan, o método Scott-Knott nunca resulta em grupos de médias sobrepostos, pois ele compara grupos ao invés de médias individuais. Apesar desta vantagem, o processo de agrupamento de Scott-Knott ainda não foi devidamente explorado pelas ciências agrárias, possivelmente devido à complexidade de seus cálculos. Neste particular, diante do grande avanço da informática, permitindo acesso a microcomputadores e calculadoras manuais programáveis pela maioria dos pesquisadores, esta dificuldade não mais se justifica, vislumbrando o uso intenso deste método, principalmente quando a intenção for separar médias em grupos homogêneos, como é o caso da classificação de genótipos em níveis de resistência a doenças e pragas.

Classificando os genótipos em três níveis de reação ao RS, resistentes, intermediários e suscetíveis, MCVX e TBIA foram equivalentes para 72 e $73 \%$ dos 11 genótipos estudados (Tabela 8), similarmente aos resultados obtidos por Iamauti \& Tokeshi (1994). Estes autores encontraram concordância de 79\% entre os resultados obtidos pelo MCVX e pelo método de observação de $C$. $x$. subsp. xyli em microscópio de contraste de fase, quando a resistência de sete genótipos, cada um representado por 40 colmos, foi avaliada em parcelas inoculadas com suco de plantas com sintomas de RS. Naquela ocasião, os autores sugeriram que a diferença entre os métodos tinha sido devida ao pequeno tempo entre a inoculação e a colheita do ensaio (três meses), tempo este não suficiente para que a bactéria do RS colonizasse os vasos do xilema e interferisse no transporte de água da planta, que é o processo fisiológico que o MCVX avalia.

A razão primária para a discordância de 27,27\% é que os genótipos L62-96 $(\% \mathrm{VNF}=9,37 ; \% \mathrm{VC}=58,99)$ e LCP82-89 $(\% \mathrm{VNF}=13,88 ; \% \mathrm{VC}=47,37)$ foram classificados como intermediárias pelo MCVX, mas suscetíveis pelo TBIA (Tabela 6). Para estes dois genótipos, $C$. $x$. subsp. $x y l i$ estava presente no xilema; no entanto, o transporte de água não foi completamente evitado, sendo as possíveis causas para tal 
comportamento discutidas no item 4.2.2. Também, o oposto foi observado para LCP87491, ou seja, este genótipo teve reação suscetível pelo MCVX (\%VNF $=21,19)$ enquanto intermediária pelo TBIA ( $\%$ VC $=26,09)$, devido ao fato de que a maioria dos VC estavam obstruídos (Tabela 6). Desde que esta alternância de reação ao RS ocorreu apenas entre genótipos suscetíveis e intermediárias, ela representa pouca influência em programas direcionados à identificação e seleção de genótipos resistentes. Em suporte a esta afirmativa vem o resultado com o genótipo CP52-68: previamente descrito como resistente (Gillaspie et al., 1976; Dean, 1983; Koike et al., 1982), foi classificado como tal pelo dois métodos MCVX e TBIA (Figura 22). Além disso, a correlação entre \%VC e correspondente \%VNF com $\mathbf{r}=0,676$ para os 11 genótipos testados, aumentou para $\mathbf{r}$ $=0,920$ quando os quatro genótipos mais suscetíveis (CP76-331, CP74-383, L62-96 e LCP82-89) foram retirados da análise (Figura 25), similarmente ao obtido para os genótipos moderadamente resistentes testados no item 4.2.2 (Figura 20). Por esta razão, tanto MCVX como TBIA podem ser utilizados para selecionar genótipos resistentes ao RS em estágios iniciais dos programas de melhoramento genético da cana-de-açúcar.

Os bons resultados obtidos pelo TBIA no presente estudo já eram esperados, pois este trata-se de um método de uso já consagrado no programa de melhoramento genético da cana-de-açúcar da Flórida (Comstock et al., 1993; Comstock et al., 1996ab; Davis et al., 1994; Miller et al., 1995). Naquele programa, o "screening" para resistência ao RS começa no terceiro ano de seleção, com aproximadamente 1.000 genótipos, sendo $15 \%$ deles classificados como suscetíveis por apresentarem acima de 10 VC (Comstock et al, 1996b). Análises de progênies têm demostrado que 16,6 ou 9,3\% de genótipos resistentes podem ser obtidos utilizando-se como limiar $\mathrm{VC}=4$ e 2 , respectivamente (Miller et al., 1995). Como a herdabilidade da resistência ao RS é alta (Miller et al., 1995), o incremento no uso de parentais resistentes combinado com "screening" para resistência nos estágios iniciais e finais do melhoramento genético têm permitido o desenvolvimento de genótipos resistentes ao RS. Esta estratégia está sendo conduzida com sucesso, permitindo o desenvolvimento de seis novos genótipos com boa resistência ao RS, somada a excelente potencial produtivo (Comstock, 1996a). 
Diante do exposto, embora alguns genótipos suscetíveis suportem alta taxa de colonização pela bactéria do RS sem contudo terem a funcionalidade de seus vasos afetada na mesma magnitude, relativo sucesso também poderia ser obtido pela seleção de genótipos resistentes com base no parâmetro \%VNF determinado pelo MCVX. Esta afirmativa é suportável, pois o número de vasos funcionais de colmos de cana-de-açúcar inoculados com caldo bruto de plantas infectadas pelo RS apresenta boa correlação com a vazão de água através desses colmos (Chagas \& Tokeshi, 1994a; Cruz, 1983; Davis \& Harrison, 1987; Valarini, 1978) que, por sua vez, está relacionada com os níveis de resistência determinados por medida de produção (Douglas, 1981). Também, a diferença de \%VNF entre parcelas sadias e doentes foi sugerida para separar culivares resistentes e suscetíveis e, através de modelos de regressão linear, tendências de danos de produtividade agro-industriais puderam ser expressas em função da \%VNF para sete dentre 10 genótipos testados (Chagas, 1996). Este tipo método de quantificação de doenças vasculares não é exclusivo do patossistema $C$. $x$. subsp. xyli - cana-de-açúcar. O bloqueio dos vasos em seç̧ões de caules de plantas de tomate infectadas por Fusarium oxysporum f. sp. lycopersici já era avaliado, na década de 50, pelo movimento de solução corante à base de eosina ou fucsina básica, sendo o número de vasos não funcionais proporcional à severidade do sintoma de murcha causado pelo fungo (Scheffer \& Walker, 1953).

Considerando que, nas fases mais adiantadas dos programas de melhormento genético da cana-de-açúcar, genótipos intermediários pelo MCVX e com excelente potencial produtivo não fossem descartados, correria-se o risco de se selecionar um material com intensa colonização dos vasos (alta \% VC), ou seja, suscetível pelo TBIA, mas com poucos vasos entupidos (baixa \%VNF). Isto caracteriza uma desvantagem do MCVX, pois este genótipo, caso fosse liberado para cultivo comercial, contribuiria com uma quantidade de inóculo muito maior do que aquela prevista pela \%VNF e, como conseqüência, a disseminação da doença também seria mais intensa. Porém, como o uso de genótipos intermediários deve ser acompanhado de medidas fitossanitárias complementares, como tratamento térmico e descontaminação de equipamentos de colheita, tal desvantagem não chega a ser restritiva. Assim, a 
redução do inóculo inicial e da disseminação do patógeno pelo tratamento térmico e descontaminação de equipamentos de colheita, respectivamente, contribuiria para evitar perdas causadas pelo RS, caso este genótipo viesse a ser liberado para cultivo comercial. Por outro lado, o TBIA requer equipamentos, reagentes e auxiliares com conhecimento muitas vezes aquém da realidade financeira dos programas de melhoramento genético da cana-de-açúcar, principalmente em países em desenvolvimento. Nestas condições, MCVX é uma ferramenta alternativa à disposição de fitopatologistas e melhoristas pois, ele tem aplicabilidade em condições de campo, requer materiais de custos reduzidos e permite a avaliação de uma grande quantidade de amostras num tempo reduzido (Iamauti \& Tokeshi, 1994), com eficiência comparável à do TBIA.

\subsubsection{Identificação de genótipos de cana-de-açúcar tolerantes ao RS}

Não existiu correlação significativa entre \%VC $(r=-0,133)$ nem \%VNF $(r=$ $-0,357$ ) com danos em produção (Figuras 26 e 27), pelo fato da existência de diferentes níveis de tolerância dentre os genótipos estudados (Tabela 8). Considerando a \%VC, como não foram observados danos significativos na produtividade em toneladas de cana por hectare para CP76-331, LCP82-89 e CP65-357, estes genótipos toleraram abundante colonização de seus tecidos vasculares por $C$. $x$. subsp. $x y l i$ e, consequetemente, foram classificados como tolerantes ao RS. Por outro lado, pequena intensidade de colonização já foi suficiente para causar danos significativos nos genótipos LCP87-491, LCP87-17, CP72-370 e HoCP85-845, sugerindo-os como intolerantes. Para os genótipos suscetíveis CP74-383, LCP62-96 e CP70-321, também foram observados danos significativos.

A \%VNF $(13,88)$ do genótipo tolerante LCP82-89 foi muito menor que a \%VC $(47,37$ ) (Tabela 8), sugerindo, a exemplo do discutido no item 4.2.2, que fatores intrínsecos da planta que impedem o entupimento dos vasos intensamente colonizados por C. $x$. subsp. $x y l i$ estariam contribuindo para tolerância ao RS. Porém, como a produção de outro genótipo, o L62-96, foi significativamente afetada pela intensa colonização dos vasos $(\% \mathrm{VC}=58,99)$ (Tabela 8$)$, mesmo tendo este poucos vasos 
entupidos (\%VNF=9,37), a manutenção da funcionalidade dos vasos colonizados não foi suficiente para determinar tolerância ao RS. Apesar de a absorção da solução corante pelos vasos colonizados da L62-96 não ter sido evitada completamente, o transporte de água e nutrientes pode ter sido limitado, possivelmente pela diminuição do fluxo de água através desses vasos. Este déficit nutricional durante a formação e desenvolvimento dos colmos resultaria em redução de crescimento, resultando em danos na produtividade. observado neste genótipo. Esta hipótese tem sustento, pois a diferença de vazão entre parcelas sadias e doentes tem se correlacionado positivamente com danos na produção (Davis \&Harrison, 1987; Douglas, 1981). Portanto, a associação do método conciliado MCVX/TBIA com o método do fluxômetro (Valarini, 1978; Valarini \& Tokeshi, 1981), possibilitando avaliar a colonização, entupimento e vazão de colmos doentes, poderia contribuir para melhor definir os mecanismos de tolerância ao RS.

A tolerância apresentada pela CP76-331 também sugere que a manutenção da funcionalidade dos vasos colonizados não é suficiente para explicar tal reação em todos os genótipos. Este genótipo não teve sua produtividade afetada pelo RS, mesmo tendo a \%VNF $(47,72)$ significativamente maior que a do L62-96 (\%VNF $=9,37)$. Neste caso, a tolerância foi determinada por outros fatores, sendo sugestiva a inclusão do fenômeno da compensação da redução do fluxo transpiratório nos xilemas colonizados pela intensificação da absorção de seiva bruta pelos vasos sadios, como mecanismo para tal evento. Esta hipótese se baseia no fato de que, intactos se alguns vasos estão fora de ação, a constante necessidade de parte do sistema pode resultar em aumento da taxa de fluxo através de vasos (Talboys, 1968).

Diferenças entre genótipos quanto aos efeitos do entupimento dos vasos na produtividade foram também observadas por Chagas (1996), quando a porcentagem de redução em quilogramas de açúcar por parcela foi estimada para cada unidade de índice de severidade do RS (ISRS). Para tanto, o ISRS expresso em porcentagem foi calculado com base na diferença de \%VNF entre parcelas inoculadas com caldo de cana infectada por C. $x$. subsp. xyli e parcelas controle. Dentre 10 genótipos estudados, o índice de dano variou desde 0,2 a 2,96, indicando diferentes níveis de tolerância ao RS. Portanto, embora o entupimento físico dos vasos do xilema por geis (Kao \& Damann, 1980), 
gomas, e pela própria célula bacteriana (Steindl, 1961; Weaver et al.. 1977) seja considerado o principal mecanismo que determina as perdas causadas pelo RS (Gillaspie et al., 1973), outros fatores, além da mera prevenção no transporte de água, podem estar interferindo na intensidade do dano.

Processos inatos da planta que regulam a taxa de transpiração (perda de água) e sensibilidade à prevenção no transporte de seiva bruta pelos vasos do xilema também poderiam estar envolvidos como mecanismos de tolerância ao RS. Diante da crucial importância do processo de absorção e translocação de água, as plantas terrestres têm desenvolvido, no curso de sua evolução, vários tecidos e mecanismos para assegurar o suprimento adequado de água como matéria prima para muitos processos fisiológicos ou como solvente de muitos compostos orgânicos e inorgânicos (Suitic \& Sinclair, 1991). Assim, interligando o movimento de água desde as raízes até as folhas, o xilema é responsável por grande parte da distribuição de muitos nutrientes essenciais ao metabolismo da planta. Porém, como o movimento de água é função de mudanças no conteúdo de solutos causadas pelo metabolismo e por gradientes de temperatura por toda a planta, ou seja, é função do fluxo transpiratório (Vaadia et al., 1961), a presença do patógeno e seus metabólitos, geis, gomas e tiloses, contribui mas não é a única causa de alteração no fluxo de água em vasos infectados. Qualquer órgão ou mecanismo, desde as raízes até as folhas, que altere o fluxo transpiratório em plantas doentes pode então afetar a movimentação de água, distribuição de nutrientes e, consequentemente, estar relacionado à tolerância da planta a doenças que reduzem a eficiência do transporte de água. Apesar de estudos preliminares não terem mostrado diferenças significativas na transpiração de plantas com RS e sadias (Kao \& Damann, 1980), este fenômeno precisa ser melhor investigado, pois redução foi demonstrada para outros patossistemas (Beckman et al., 1953; Dimond \& Waggoner, 1953). Como exemplo, folhas de plantas de tomateiro com os vasos do xilema da haste colonizados pelo fungo Fusarium oxysporum f. sp. lycopersici, patógeno que também causa murcha e subdesenvolvimento, transpiraram um terço menos, e seus estômatos permaneciam mais tempo fechados que folhas de plantas sadias, numa tentativa de contornar o déficit hídrico e nutricional gerado pelo ataque do patógeno (Dimond \& Waggoner, 1953). 
Como a manutenção da funcionalidade do vasos do xilema de colmos de cana-de-açúcar colonizados por $C$. $x$. subsp. xyli não foi suficiente para determinar tolerância ao RS, o método conciliado MCVX/TBIA só identificou genótipos tolerantes quando associado com dados de produção de parcelas sadias e doentes (Tabela 8). Esta associação é de capital importância para a liberação e orientação do manejo de genótipos, visando o controle do RS, pois, no decorrer dos programas de melhoramento genético da cana-de-açúcar, os genótipos têm que apresentar múltiplas qualidades agronômicas e industriais, além de resistência às principais doenças que afetam a cultura. Então, não é aconselhável pressionar a seleção para resistência ao RS a ponto de descarte de genótipos tolerantes. Tais genótipos podem ser liberados para o cultivo comercial, adotando-se medidas fitossanitárias complementares para evitar o aumento excessivo do inóculo em regiões canavieiras. Portanto, é recomendada a adoção do MCVX e/ou TBIA associados a dados de produção (YDT) para identificar genótipos tolerantes dentre aqueles intermediários ou suscetíveis, mas com excelente potencial para uso comercial. Como os efeitos do RS na produção são influenciados por fatores extra como tipo, fertilidade (Wang, 1966) e, especialmente, o teor de umidade do solo (Rossler, 1974; Steindl, 1961; Wang, 1966), a reação de tolerância apresentada pelos genótipos no presente estudo poderia ser diferente em outras condições. Por este motivo, pelo menos dois experimentos em anos e/ou locais diferentes precisam ser conduzidos para maior precisão dos resultados. Para este propósito, experimentos "microplots" (Matsuoka, 1980) ou "single stools" (Dean, 1983) poderiam ser implementados nos programas de melhoramento para determinar os danos causados pelo RS e, consequentemente, identificar genótipos tolerantes o mais cedo possível. Comparados aos experimentos normais de avaliação de danos causados pelo RS (Grisham, 1991; 1994), as parcelas reduzidas dos delineamentos "microplots" e "single stools" seriam úteis para racionar custos e mão de obra requeridos. 


\section{DISCUSSÃO GERAL}

Depois de um longo período de pesquisa para o desenvolvimento, padronização e aferição do MCVX (Valarini, 1978; Douglas, 1981; Cruz, 1983; Chagas, 1986; Iamauti, 1990; Chagas \& Tokeshi, 1994ab; Iamauti \& Tokeshi, 1994; Chagas, 1996), os resultados de correlações significativas entre \%VNF e \%VC obtidos no presente estudo não deixam dúvidas de que a identificação de genótipos de cana-deaçúcar resistentes ao RS pode ser orientada tanto pela intensidade da colonização dos vasos do xilema por $C$. $x$. subsp. xyli como pelo respectivo efeito na funcionalidade dos mesmos. Portanto, aqueles que não dispõem de reagentes e equipamentos requeridos pelo já consagrado TBIA, MCVX pode ser utilizado como uma ferramenta alternativa para a identificação da resistência.

Apesar de o entupimento físico dos vasos por géis (Kao \& Damann, 1980), gomas e pela própria célula bacteriana (Steindl, 1961; Weaver et al., 1977) ser entendido como o principal fator que induz à redução da produtividade de plantas com $\mathrm{RS}$, tanto a \%VC como a \%VNF não se correlacionaram com danos, sugerindo que, além da mera prevenção no transporte de água, outros fatores podem estar envolvidos. Neste particular, a aplicação do método conciliado MCVX/TBIA no patossistema canade-açúcar - $C$. $x$. subsp. xyli representa u m modelo bastante interessante de como medir alterações fisiológicas no hospedeiro induzidas por bactérias habitantes do xilema e respectivos efeitos indiretos na produtividade de plantas doentes. Aliado a métodos histológicos e bioquímicos, MCVX/TBIA poderia trazer grandes contribuições para o melhor entendimento fisiopatológico desse patossistema. Como exemplo, seria útil para elucidar se a obstrução dos vasos é induzida por mecanismos de ataque do patógeno e/ou por mecanismos de defesa do hospedeiro, estabelecer o que ocorre a nível histológico e bioquímico em genótipos que apresentam poucos vasos obstruídos apesar de intensa colonização dos mesmos, e determinar outros fatores possivelmente envolvidos nos mecanismos de tolerância. Seria a redução do fluxo transpiratório nos xilemas obstruídos compensada pela intensificação da absorção de seiva elaborada nos vasos sadios um desses mecanismos de tolerância? O que ocorre a nível de abertura e 
fechamento de estômatos? Podem alguns genótipos conviverem com certo déficit hídrico?

O uso do MCVX para a identificação de genótipos resistentes foi inicialmente sugerido com base na correlação entre diferença de vazão de água e vasos funcionais e diferença de produção entre parcelas sadias e doentes (Cruz, 1983; Douglas, 1981; Valarini, 1978). De maneira análoga, o uso do TBIA era justificado pela correlação da colonização do hospedeiro pelo patógeno com danos na produção (Davis et al., 1994; Miller et al., 1995). Porém, após a realização do presente estudo, o ponto de vista é diferente: a premissa para o uso desses métodos é que a população do patógeno disponível para o desenvolvimento do RS é o principal parâmetro epidemiológico que deve ser controlado para reduzir perdas. Tal premissa é justificada, pois a evolução de uma epidemia é função da densidade populacional do patógeno para dar início ao processo e do aumento dessa população no tempo e no espaço (Zadocks \& Schein, 1979), o que também é válido para o RS.

A população inicial de $C . x$. subsp. $x y l i$ para dar início à evolução do RS é determinada pelo número de colmos que ficam infectados e pelo tamanho da população que desenvolve nesses colmos entre o tempo de infecção e disseminação, ou seja, é função da incidência e severidade do RS, respectivamente. Quanto ao aumento populacional no tempo e no espaço, uma relação direta tem sido observada entre a intensidade de colonização de colmos (severidade) de diferentes genótipos de cana-deaçúcar e a taxa de disseminação do RS (Comstock et al., 1996b). Isso ocorre porque a concentração da bactéria do RS requerida para infectar a mesma proporção de toletes varia entre genótipos, e é inversamente correlacionada com a população do patógeno que se desenvolve após a infecção (Harrison \& Davis, 1986). Então, uma epidemia não seria sustentada em um genótipo altamente resistente, onde um inóculo concentrado é requerido, mas um inóculo diluído é fornecido. A meta principal de um programa de melhoramento com respeito ao RS poderia então ser direcionada para o desenvolvimento de genótipos com alto potencial produtivo que não sustentariam uma epidemia. Tanto TBIA como MCVX, permitiriam uma comparação direta do potencial para o progresso da doença em diferentes genótipos. Selecionando para baixa \%VNF ou 
$\% \mathrm{VC}$ estar-se-ia indiretamente selecionando materiais que suportariam baixo inóculo inicial (quantidade de inóculo nas mudas $=$ Xo) e baixa taxa aparente de infecção (velocidade de crescimento da doença ao longo dos cortes $=r$ ), retardando ou até mesmo impedindo a ocorrência de níveis epidêmicos de RS.

Devido ao fenômeno da tolerância, definida aqui como a habilidade de um genótipo de cana-de-açúcar sofrer poucos danos e perdas apesar de alta severidade de doença, é possível que para genótipos que sustentam similar dano devido ao RS tenham potencial epidêmico diferente. Por isso, selecionando para baixo nível de colonização ou entupimento poder-se-ia promover rápido progresso na prevenção de epidemias pela seleção indireta de genótipos que sofreriam menores danos e perdas pelo RS. Como no presente estudo o nível de dano causado pelo RS não foi determinado exclusivamente pela intensidade de colonização, nem pela diminuição no fluxo de água através do vasos do xilema, esta estratégia teria ainda maior sucesso, se MCVX ou TBIA fossem associados com dados de produção de parcelas sadias e doentes. A identificação do nível de resistência e tolerância de cada genótipo, previamente à sua liberação, permitiria uma recomendação para reduzir o Xo e r, através da produção de mudas sadias e descontaminação de equipamentos de colheita, respectivamente, em genótipos intolerantes ou com potencial epidemiológico elevado.

Um sistema de orientação para a tomada de medidas de controle do RS baseado na resistência e tolerância de genótipos de cana-de-açúcar em muito contribuiria para racionalizar o manejo varietal, visando manter a doença abaixo do nível econômico de dano, para que não haja comprometimento da produtividade de canaviais comerciais. Atualmente, a indisponibilidade de tal sistema de orientação tem causado certo mal estar junto aos departamentos de planejamento das unidades produtoras de cana-de-açúcar. Considerando a teoria de que "controle em excesso é tão ineficiente quanto ausência de controle" (Bergamin Filho \& Amorim, 1996), os técnicos das usinas ficam diante de um dilema: tratar as mudas de todos os genótipos e gastar desnecessariamente com aqueles que são resistentes? Ou não tratar nada e perder dinheiro com os intolerantes? O balanço econômico entre os gastos desnecessários e as perdas causadas pela bactéria $C$. $x$. subsp. xyli é, obviamente, função da proporção da 
área que é ocupada por genótipos suscetíveis e intolerantes. Portanto, o dilema de tratar ou não seria, em grande parte, resolvido se genótipos com baixo potencial epidemiológico e perdas fossem identificados dentre todos aqueles liberados para uso comercial. Apenas genótipos com potencial epidemiológico elevado seriam submetidos ao tratamento térmico e à descontaminação de equipamentos de colheita. Esta racionalização não mais permitiria gastos por falta ou excesso de medidas fitossanitárias, permitindo maior adesão e sucesso ao controle integrado do RS.

O setor canavieiro brasileiro mostra-se bastante apto a um sistema de orientação para o controle integrado do RS, pois o desenvolvimento de genótipos está sendo conduzido de maneira integrada pelos programas de melhoramento e setor produtivo (Matsuoka et al., 1997). A ampliação da rede de experimentação e trocas de informações têm sido estabelecida pelos pesquisadores junto aos técnicos que efetivamente conduzem a cultura da cana-de-açúcar, permitindo uniformização da linguagem para gerar mais informações e aumentar a eficiência durante a condução do programa de desenvolvimento de novos genótipos. Esta intensa atividade de experimentação tem proporcionado, mesmo que inconscientemente, um ganho em tolerância ao RS ao longo do tempo. De acordo com o censo varietal para o Estado de São Paulo (Gheller, 1996), o genótipo CB41-76, intolerante ao RS (Matsuoka, 1980), imperou durante toda a década de 70. Posteriormente, NA56-79 dominou nos anos 80, sendo superada somente em 1988 pela SP70-1143. Este genótipo foi ultrapassado em 1993 pelo SP71-6163, tolerante ao RS (Sanguino, 1993) que, principalmente em função da Síndrome do amarelecimento das folhas (YLS) teve vida curta e, desde 1995, a RB72454 ocupa o espaço de genótipo mais explorada comercialmente em todo Brasil. Por fim, analisando dados obtidos por Chagas (1996), em cana-soca, os genótipos NA56-79, SP70-1143 e RB72454 apresentaram índice de dano em quilogramas de açúcar por hectare igual a 2,96, 1,06 e 0,56\%, respectivamente, para cada unidade de índice de severidade do RS. Portanto, desde a década de 70, com a CB41-76, até os dias de hoje, com a RB72454, houve um aumento gradual na tolerância ao RS. Tal fato explica, pelo menos em parte, o abandono progressivo do tratamento térmico, amplamente utilizado na década de 80 (Ruas et al., 1987). Se este relativo sucesso foi 
conseguido de maneira inconsciente, sem nenhum programa direcionado para este fim, é possível vislumbrar sucesso muito maior, caso MCVX ou TBIA, associados a dados de produção de parcelas sadias e doentes, fossem aplicados em testes de rotina para orientar a escolha e manejo de genótipos de cana-de-açúcar para o controle integrado do RS. 


\section{CONCLUSÕES}

Diante dos resultados obtidos nas condições do presente estudo, pode-se concluir que:

- Uma pequena amostra circular de $10 \mathrm{~mm}$ de diâmetro por $10 \mathrm{~mm}$ altura é suficiente para representar toda a secção transversal de internódios de cana-de-açúcar;

- A porcentagem representa a severidade do RS melhor que o número absoluto de vasos colonizados e não funcionais, pois considera a diferença no total de vasos amostrados em cada genótipo;

- TBIA e MCVX demonstraram o mesmo padrão de colonização de colmos de cana-de-açúcar por $C$. $x$. subsp. xyli: a alta intensidade de colonização dos vasos distribuídos no centro do internódio diminui progressivamente à medida que se aproxima dos tecidos da epiderme;

- A intensidade da colonização de colmos de cana-de-açúcar por C. $x$. subsp. xyli está significativamente correlacionada com seus respectivos efeitos na funcionalidade dos vasos do xilema, quando genótipos moderadamente resistentes são analisados;

- Alguns genótipos de cana-de-açúcar suportam alta taxa de colonização de seus vasos por $C$. $x$. subsp. $x y l i$, sem contudo terem a funcionalidade desses vasos afetada na mesma magnitude;

- MCVX consiste numa excelente ferramenta alternativa ao TBIA para identificação de genótipos de cana-de-açúcar resistentes ao RS, principalmente em 
países cujos recursos financeiros para o desenvolvimento de novos cultivares são escassos;

- O método de análise de agrupamento Scott-Knot permitiu a classificação de cultivares de cana-de-açúcar em diferentes níveis de resistência ao RS, tendo a vantagem sobre o teste de Duncan de eliminar qualquer efeito subjetivo no momento da separação dos níveis;

- Diferentes níveis de tolerância ao RS foram responsáveis pela não correlação entre severidade de doença (\%VC e \%VNF) e danos em produção;

- Embora o entupimento físico do xilema por géis, gomas e pela própria célula bacteriana seja considerado o principal mecanismo que determina as perdas causadas pelo RS, a manutenção da funcionalidade dos vasos colonizados por $C$. $x$. subsp. xyli não foi suficiente para explicar a tolerância observada em diferentes cultivares;

- MCVX/TBIA não foi suficiente para identificar cultivares de cana-deaçúcar tolerantes ao RS, sendo necessário, para este fim, o confronto desse método com experimentos para obtenção de dados de produção de parcelas sadias e doentes;

- A premissa para o uso tanto do TBIA como do MCVX para identificação de genótipos de cana-de-açúcar resistentes ao RS é que a população do patógeno disponível para o desenvolvimento do RS é o principal parâmetro epidemiológico que deve ser controlado para reduzir perdas;

- O método conciliado MCVX/TBIA permite a avaliação da intensidade de colonização de colmos de cana-de-açúcar por $C$. $x$. subsp. xyli e os respectivos efeitos na funcionalidade dos vasos do xilema; 
- O desenvolvimento do método conciliado MCVX/TBIA para o patossistema $C . x$ subsp. xyli-cana-de-açúcar representa uma evolução bastante interessante, no que se refere a modelos para medir alterações fisiológicas no hospedeiro induzidas por bactérias habitantes do xilema e respectivos efeitos indiretos na produtividade de plantas doentes; 


\section{REFERÊNCIAS BIBLIOGRÁFICAS}

ABBOTT, E.V. El raquitismo del retoño de la canã de azucar y forma de disseminário. Boletim Oficial de la Asociacion de Tecnicos Azucareros de Cuba, 17:457-66, 1958.

ABBOTT, E.V. \& ZUMMO, N. Effect of ratoon stunting disease on yield of some sugar canevarieties in Louisiana. Sugar Bulletin, 40: 226-9, 1962.

ALMEIDA, I.M.G. Bacterial diseases of sugarcane in Brazil. In: RAO, G.P; GILLASPIE Jr., A.G.; UPADHYAYA, P.P.; BERGAMIN FILHO, A.; AGNIHOTRI, V.P. \& CHEN, C.T. eds. Current trends in sugarcane pathology. New Delhi: International Books \& Periodicals Supply Service, 1994. 449p.

ANTOINE, R. Cane diseases. Review of Appl. Mycology, 36:616-7, 1957.

ANTOINE, R. Ratoon stunting disease. In. MAURITIUS SUGAR INDUSTRY RESEARCH ISTITUTE. Port Louis, ANNUAL REPORT 1958, p. 51-8, 1959.

ANTOINE, R. \& RICAUD, C. Cane diseases. In: MAURITIUS SUGAR INDUSTRY RESEARCH INSTITUTE. Port Louis. Annual Report 1963, Port Louis, p. 75-89, 1964.

AMORIM, L. Ciclo das relações patógeno-hospedeiro. In: BERGAMIN FILHO, A.; KIMATI, H. \& AMORIM, L. Manual de Fitopatologia. São Paulo: Agronômica Ceres, 1995. v.1., p.234-342.

ARTSCHWAGER, E. Anatomy of the vegetative organs of sugarcane. J. Agric. Res., 30:197-221, 1925. 
ASTUA-MONGE, G. Detection of Clavibacter xyli subsp. xyli, the causal agent of ratoon stunting disease of sugarcane, based on amplification of DNA in the ribosomal DNA spacer, Gainesville, 1995. 58p. (Master of Science - University of Flórida).

AUTREY, L.J.C.; DOOKUN, A.; SAUMTALLY, S.; DHAYAN, S. \& SULLIVAN, S. Soil transmission of the ratoon stunting disease bacterium Clavibacter xyli subsp. xyli. Sugar Cane, 6:5-6, 1991.

BAILEY, R.A. The systemic distribution and relative occurrence of bacteria in sugarcane varieties affected by ratoon stunting disease. Proceedings of the South African Technologists Association, 6(9):466-7, 1977.

BAILEY, R.A. \& TOUGH, S.A. Mechanisms of infection of sugar cane by the ratoon stunting disease bacterium Clavibacter xyli subsp. xyli. Sugar Cane, 6:5, 1991.

BECHET, G.R. Ratoon stunting disease and rapid diagnostic techniques. The South African Sugar Journal, 60(10):539-45, 1976.

BECKMAN, C. H. ; KUNTZ, J.E.; RIKER, A.J. \& BERBEE, J.G. Host responses associated with development of oak wilt. Phytopathology, 43:448-54, 1953.

BENDA, G.T.A. Increased survival of young seed cane after hot-water treatment for RSD control. Sugar Bulletin, 56(19):7-8, 13-14. 1978.

BENDA, G.T.A. Studies on the wilt of a sorghum-sudangrass hybrid infected with ratoon stunting disease of sugarcane. Proceedings of the American Phytopathological Society., 2:65, 1975. 
BENDA, G.T.A. \& RICAUD, C. The use of heat tratment for sugarcane disease control. Proceedings of the International Society of Sugar Cane Technologists, 16:483-496, 1978.

BERGAMIN FILHO, A. \& AMORIM L. Doenças de plantas tropicais: epidemiologia e controle econômico. Piracicaba: Agronômica Ceres, 1996. 291p.

BETTI, J.A.; COSTA, A.S.; PARADELA, F.O.; SOAVE, J. \& MATSUOKA, S. Descoloração vascular na região dos nós em capim elefante causada por várias espécies de bactérias. Fitopatologia Brasileira, Brasília, 5(2):139-47, 1980.

BRIEGER, F. O. Raquistismo da soqueira. Boletim Informativo COPERESTE. Ribeirão Preto, 6:1-5, 1967.

BRIGGS, K. G. \& SHEBESKI, L. H. Early generation selection for yield and bread making quality of hard red spring wheat (Triticum aestivum L.). Euphytica, 20:453-63, 1971.

CAMPBELL, C.L. \& MADDEN, L.V. Introduction to plant disease epidemiology. New York: John Wiley \& Sons, 1990. 531p.

CAMPOS, H. Testes apropriados a dados pareados, teste do sinal. In: CAMPOS, H. Estatística experimental não-paramétrica. 4.ed. Piracicaba: FEALQ, 1983. cap.3, p.65-76.

CHAGAS, P.R.R. Método de coloração do xilema, pelo fluxo transpiratório, aplicado na determinação da infeç̧ão do raquitismo-da-soqueira em cana-de-açúcar. Piracicaba, 1986. 123p. Dissertação (Mestrado) - Escola Superior de Agricultura "Luiz de Queiroz", Universidade de São Paulo.

CHAGAS, P.R.R. Raquitismo-da-soqueira: severidade dos sintomas do xilema e quantificação de danos agro-industriais. Piracicaba, 1996. 161p. Dissertação 
(Doutorado) - Escola Superior de Agricultura "Luiz de Queiroz", Universidade de São Paulo.

CHAGAS, P.R.R. \& TOKESHI, H. Método alternativo de coloração do xilema para avaliação do índice de contaminação do raquitismo da soqueira em cana-de-açúcar. Brasil Açucareiro, 106(4): 16-24, 1988.

CHAGAS, P.R.R. \& TOKESHI, H. Comparison between methods for diagnosis of ratoon stunting disease: I. Water flow, flow and staining and staining by transpiration. In: RAO, G.P.; GILLASPIE Jr. A.G.; UPADHYAYA, P.P.; BERGAMIN FILHO, A.; AGNIHOTRI, V.P.; CHEN, C.T., eds. Current trends in sugarcane pathology. New Delhi: International Books \& Periodicals Supply Service, 1994a. p.163-71.

CHAGAS, P.R.R. \& TOKESHI, H. Staining by transpiration method for the diagnosis of ratoon stunting disease in sugarcane. In: RAO, G.P.; GILLASPIE Jr. A.G.; UPADHYAYA, P.P.; BERGAMIN FILHO, A.; AGNIHOTRI, V.P.; CHEN, C.T., eds. Current trends in sugarcane pathology. New Delhi: International Books \& Periodicals Supply Service, 1994b. p. 159-62.

CHO. Y.S.; WILCOXSON, R.D. \& FROSHEISER, F.I. Diferences in anatomy, plantextracts and movement of bacteria in plants of bacterial wilt resistant and susceptible varieties of alfafa. Phytopathology, 63:760-5, 1973.

CHU, H.T. \& LEE, S.M. Ratoon stunting disease control in Taiwan. Proceedings of the International Society of Sugar Cane Technologists, 13:1124-9, 1968.

COMSTOCK, J.C.; MILLER, J.D.; SHINE, J.M., Jr. \& TAI, P.Y.P. Screening for resistance to ratoon stunting disease in Florida. Proceedings of the International Society of Sugar Cane Technologists, 22:520-6, 1996a. 
COMSTOCK, J.C.; SHINE, J.M., Jr.; DAVIS, M.J. \& DEAN, J.L. Relationship between resistance to Clavibacter xyli subsp. xyli colonization in sugarcane and spread of ratoon stunting disease in the field. Plant Disease, 80(6):704-8, 1996b.

COMSTOCK, J.C.; SHINE, J.M., Jr. \& PERDOMO, R. Ratoon stunting disease in Florida's non-hot-water treated sugarcane seedfields. J. Am. Soc. Sugar Cane Technol., 13:14-7, 1993.

CRUZ, M.M. Avaliação de resistência ao raquitismo da soqueira pela vazão de água em colmos de cana-de-açúcar e a interferência da escaldadura das folhas no método. Piracicaba, 1983. 51p. Dissertação (Mestrado) - Escola Superior de Agricultura "Luiz de Queiroz", Universidade de São Paulo.

DAMANN Jr., K.E. Alkaline-induced metaxylem autofluorescence: a diagnostic symptom of ratoon stunting disease of sugarcane. Phytopathology, 78(2):23-6, 1988.

DAMANN Jr., K. E. Effect of sugarcane cultivar susceptibility on spread of ratoon stunting disease by the mechanical harvester. Plant Disease, 76:1148-9, 1992.

DAMANN Jr., K. E., \& HOLLIER, C. A. Distribution and incidence of ratoon stunting disease in Louisiana sugarcane. Plant Disease, 75:568-71, 1991.

DAMANN Jr., K.E.; OGUNWOLU, E.O. \& REAGAN, T.E. Incidence of ratoon stunting disease in Louisiana. (Abstract) Phytopathology, 74:627, 1984.

DAVIS, M. J. Direct-count techniques for enumerating Clavibacter xyli subsp. xyli which causes ratoon stunting disease of sugarcane. Phytopathology, 75:1226-31, 1985.

DAVIS, M.J. Taxonomy of plant-pathogenic coryneform bacteria Annual Review of Phytophatology, 24:115-140, 1986. 
DAVIS, M.J. \& DEAN, J.L. Comparison of diagnostic techniques for determinig incidence of ratoon stunting disease in Flórida. Plant Disease, 68(10):896-9, 1984.

DAVIS, M.J. \& HARRISON, N.A. Hydraulic conductivity in sugarcane clones as related to resistance to ratoon stunting disease. In Plant Pathogenic Bacteria, E.L. CIVEROLO, A. COLlMER, R.E. DAVIS \& A.G. GILlASPIE, Jr., eds., Boston: Martinus Nijhoff. pp. 613-6, 1987.

DAVIS, M.J., DEAN, J.L. \& HARRISON, N.A.. Distribution of Clavibacter xyli subsp. $x y l i$ in stalks of sugarcane cultivars differing in resistance to ratoon stunting disease. Plant Disease, 72:443-448, 1988a

DAVIS, M J., DEAN J.L. \& HARRISON, N.A. Quantitative variability of Clavibacter xyli subsp. xyli populations in sugarcane cultivars differing in resistance to ratoon stunting disease. Phytopathology, 78:462-468, 1988b.

DAVIS, M.J.; DEAN, J.L.; MILLER, J.D. \& SHINE, J.M., Jr. A method to screen for resistance to ratoon stunting disease of sugarcane. Sugar Cane, 6:9-16, 1994.

DAVIS, M.J. GILLASPIE, A.G,, Jr. HARRIS, R.W. \& LAWSON, R.H. Ratoon stunting disease of sugarcane: Isolation of the causal bacterium. Science, 240:1365-7, 1980.

DAVIS, M.J.; GILLASPIE Jr., A.G.; VIDAVER, A.K.; HARRIS, R.W. Clavibacter: a new genus containing some phytopathogenic coryneform bacteria, including Clavibacter xyli subsp. xyli sp. nov., subsp. nov. and Clavibacter xyli subsp. cynodontis subsp. nov., pathogens that cause ratoon stunting disease of sugarcane and bermusagrass stunting disease. International Journal of Systematic Bacteriology, 34(2):107-17, 1984.

DEAN, J.L. Single-stool plots for estimating relative yield losses caused by ratoon stunting disease of sugarcane. Plant Disease, 67(1):47-9, 1983. 
DEAN, J.L. \& DAVIS, M.J. Yield losses caused by ratoon stunting disease of sugarcane in Flórida. Journal of the American Society of Sugar Cane Technologists. 10:66-72, 1989.

DIMOND, A. E. \& WAGGONER, P. E. The water economy of Fusarium wilted plants. Phytopathology, 43:619-23, 1953.

DODSON, A. K. Equipamento para tratamento térmico desenvolvido no PLANALSUCAR. Planalsucar em notícias, (12):1-4, 1973.

DOUGLAS , R.A. Correlação entre vazão de água e resistência ao raquitismo da soqueira em cana-de-açúcar. Piracicaba, 1981. 57p. Dissertação (Mestrado) - Escola Superior de Agricultura “Luiz de Queiroz”, Universidade de São Paulo.

DUNCAN, D.B. Multiple range and multiple F tests. Biometrics, 21:11-42, 1955.

FREY, K. J. The utility of hill plots in oat research. Euphytica, 14:196-208, 1965.

GATES, C.E. \& BILBRO, J.D. Illustration of a cluster analysis method for mean separation. Agronomy Journal, 70:462-5, 1978.

GHELLER, A.C.A. Avaliação da eficiência de dois sistemas de tratamento térmico para inativação da bactéria causadora do raquitismo da soqueira em cana-deaçúcar. Piracicaba, 1986. 99p. Dissertação (Mestrado) - Escola Superior de Agricultura “Luiz de Queiroz”, Universidade de São Paulo.

GHELLER, A.C.A. Técnica cultural para o controle da podridão-abacaxi em cana-deaçúcar e modelo para estimativa de perdas. Piracicaba: 1995. 82p. Dissertação (Doutorado). Escola Superior de Agricultura "Luiz de Queiroz", Universidade de São Paulo. 
GHELLER, A.C.A. Variedades de cana-de-açúcar cultivadas no estado de São Paulo em 1995 - Censo varietal. Anais do Congresso Nacional da STAB, $6^{\circ}$ Congresso, p. 173-80, 1996.

GIGLIOTI, E. A. \& TOKESHI, H. Avaliação de perdas pelo carvão da cana-de-açúcar (Ustilago scitaminea Sydow): A compensação entre plantas não deve ser esquecida. Fitopatologia Brasileira, 18:348, 1993. (SUPLEMENTO).

GILLASPIE Jr., A.G. Ratoon stunting disease of sugarcane: serology. Phytopathology, 68(3):529-32, 1978.

GILLASPIE Jr., A. G. \& DAVIS, M. J. Ratoon stunting disease of sugarcane. In: A. N. MUKHOPADHYAY, J. KAMAR, H.S. CHAUBE, U.S. SING, eds. Plant diseases of international importance. disease of sugar, forest, and plantation crops, vol. 4, Englewood Cliffs: New Jersey, Prentice Hall. pp. 41-61, 1992

GILLASPIE Jr., A.G. \& HARRIS, R.W. Limitations of E.L.I.S.A. for detection of the RSD: associated bacterium in sugarcane and sudangrass. Sugarcane Pathologist's Newsletter, 22:25-8, 1979.

GILLASPIE Jr., A. G. \& TEAKLE, D. S. Ratoon stunting disease. In: RICAUD, C. ; EGAN, B. T. ; GILLASPIE Jr., A. G.; HUGHES, C. G. eds. Diseases of sugarcane, major diseases. Amsterdan, Elsevier, Cap. 4, p.58-80, 1989..

GILlASPIE, A. G., Jr., DAVIS, R. E. \& WORLEY, J. F. Diagnosis of ratoon stunting disease based on the presence of a specific microorganism. Plant Disease Reporter, 57(12):987-90, 1973.

GILLASPIE Jr. , A.G.; FLAX, G. \& KOIKE, H. Relationship between numbers of diagnostic bacteria and injury by ratoon stunting disease in sugarcane. Plant Disease Reporter, St. Paul, 60(7):573-5, 1976. 
GILLASPIE Jr.; IRVINE, J.E. \& STEERE, R.L. Ratoon stunting disease virus assay technique and partial purification. Phytopathology, 56:1426-7, 1966.

GRISHAM, M.P. Effect of ratoon stunting disease on yield of sugarcane grown in multiple three-year plantings. Phytopathology, 81(3):337-40, 1991.

GRISHAM, M.P. Effect of ratoon stunting disease on sugarcane yield. Annual Report of the USDA-ARS, Sugarcane Research Unit, Houma, Louisiana, p. 161-7, 1994.

HARRIS, R.W. \& GILLASPIE Jr., A.G. Immunofluorescent diagnosis of ratoon stunting disease. Plant Disease Reporter, 62(3):193-6, 1978.

HARRISON, N.A. \& DAVIS, M.J. Infectivity titrations of Clavibacter xyli subsp. xyli and sugarcane cultivars differing in susceptibility to ratoon stunting disease. Plant Disease, 70(6):556-8, 1986.

HARRISON, N. A. \& DAVIS, M.J. Colonization of vascular tissues by Clavibacter xyli subsp. xyli in stalks of sugarcane cultivars differing in susceptibility to ratoon stunting disease. Phytopathology, 78(6):722-7, 1988.

HARRISON, N. A. \& DAVIS, M.J. Comparison of serological techniques for diagnosis of ratoon stunting disease. Sugar Cane, 1990 Spring Suppl. p.5-9, 1990.

HUGHES, C.G. The economic importance of ratoon stunting disease. Procedings of the International Society of Sugar Cane Technologists, 15(1):213-7, 1974.

HUGUES, C.G. \& STEINDL, D.R.L. Ratoon stunting disease. Technical Communication Queensland Bureau of Sugar Experiment Station, 2:4, 1955. 
HUGUES, C.G. \& STEINDL, D.R.L. Testing for disease resistance. In: Annual Report of Bureau of Sugar Experiment Station, p.50-1, 1971.

IAMAUTI, M.T. Comparação de métodos para diagnose do raquitismo da soqueira da cana-de-açúcar (Clavibacter xyli subsp. xyli) e aplicação na seleção de variedades resistentes. Piracicaba, 1990. 133p. Dissertação (mestrado) - Escola Superior de Agricultura "Luiz de Queiroz", Universidade de São Paulo.

IAMAUTI, M.T. \& TOKESHI, H. Comparison between methods for diagnosis of ratoon stunting disease (Clavibacter xyli subsp. xyli): II. Staining by transpiration method, observation of bacterium in contrast phase microscope, alkaline-induced metaxylem autofluorescence. In: RAO, GP.; GILLASPIE JR., A.G. ; UPADHYAYA, P.P; BERGAMIN FILHO, A.; AGNIHOTRI, V.P.; CHEN, C.T. eds. Current trends in sugarcane pathology. New Delhi: International Books \& Periodicals Supply Service: 1994, p. 173-84.

JENSEN, N. F. \& ROBINSON, D. S. Miniature plots for cereal testing. Crop Science, 9: 288-9, 1969.

KAMIUNTEN, H. \& WAKIMOTO, S. Coryneform bacteria found in xylem of the ratoon stunting diseased sugarcane. Annals of the Phytopathological Society of Japan. 42(4):500-3, 1976.

KAO, J. \& DAMANN Jr. , K.E. In situ localization and morphology of the bacterium associated with ratoon stunting disease of sugarcane. Canadian Journal of Botany, 58(3):310-5, 1980.

KING, N.J. \& STEINDL, D.R.L. The relationship between varietal yield deterioration and ratoon stunting disease. Proceedings of the International Society of Sugar Cane Technologists, 8:852-60, 1953. 
KIMATI, H. \& BERGAMIN FILHO, A. Princípios gerais de controle. In: BERGAMIN FILHO, A.; KIMATI, H. \& AMORIM, L. eds. Manual de Fitopatologia. São Paulo, Agronômica Ceres, 1995. V.1., p.692-709.

KOIKE, H. Interaction between diseases on sugarcane. Sugarcane mosaic and ratoon stunting disease Procedings of the International Society of Sugar Cane Technologists, 15:258-65, 1974.

KOIKE, H. Interaction between mosaic and ratoon stunting disease on two commercial sugarcane clones. Sugarcane Pathologist's Newsletter, 29:44-8, 1982.

KOIKE, H.; GILlASPIE Jr. A.G. \& BENDA, G.T.A. Cane yield response to ratoon stunting disease. International Sugar Journal, 84(11):131-3, 1982.

LIU, L.J.; CORTÉS-MONLLOR, A.; MARAMOROSCH, K.; HIRUMI, H.; PÉREZ, J.E. \& BIRD, J. Isolation of an organism resembling Xanthomonas vasculorum from sugarcane affected by ratoon stunting disease. Procedings of the International Society of Sugar Cane Technologists, 15(1):234-40, 1974.

LOPEZ-ROSA, J. H. \& ADSUAR, J. Effect of stunting disease on yield of some sugarcane varieties in Puerto Rico. Journal Agricultural University Puerto Rico, 54:149-60, 1970.

MARAMOROSCH, K.; PLAVSIC-BANJAC, B.; BIRD, J. \& LIU, L.J. Electron microscopy of ratoon stunted sugar cane: microorganisms in xylem. Phytopathologische Zeitscript, 77:270-3, 1973.

MATSUOKA, S. Incidência do vírus do raquitismo da soqueira em canas provenientes de material propagativo tratado termicamente. Campinas: Instituto Agronômico, 1971. 2p. 
MATSUOKA, S. Ratoon stunting disease diagnosis with elephant-grass as a indicator plant. Sugarcane Pathologist's Newsletter, 8:10-1, 1972.

MATSUOKA, S. Recuperação da produtividade de variedades de cana-de-açúcar pelo tratamento térmico de toletes. Brasil Açucareiro, 87(5):20-4, 1976.

MATSUOKA,S. Microplots for screencing sugarcane varieties for tolerance to ratoon stunting disease. In: Proceedings of the International Society of Sugar Cane Technologists, 17:1628-38, 1980

MATSUOKA, S. Longevidade do efeito do tratamento térmico em canas infectadas pelo raquitismo da soqueira. Anais do Congresso Nacional da STAB, 3:244-9, 1984.

MATSUOKA, S. Ter ou não ter doença, eis a questão. Summa Phytopathologica, Jaguariuna, 19(34): 145-51: 1993.

MATSUOKA, S. \& AGUILLERA, M.M. Efeito aditivo de nematóides e raquitismo-dasoqueira sobre a produção de algumas variedades de cana-de-açúcar. Anais do Congresso Nacional da STAB, 2(2):409-20, 1981.

MATSUOKA, S.; ARIZONO, H.; BASSINELLO, A.I.; GARCIA, A.A.F.; GHELLER, A.C.A.; GIGLIOTI, E.A.; HOFFMANN, H.P.; MASUDA, Y. \& SANTOS, G.H.R. Parceria UFSCar-Empresa para o melhoramento genético da cana-de-açúcar. Stab, 15(5):12, 1997.

MILLER, J.D.; DAVIS, M.J.; DEAN, J.L. \& SHINE, J.M., Jr. Heritability of resistance to ratoon stunting disease in Sugarcane. Sugar Cane, 1:3-8, 1995.

NELSON, P.E. \& DICKEY, R.S. Histopathology of plants infected with vascular bacterial pathogens. Annual Review of Phytopathology, 8:259-80, 1970. 
PLAVSIC-BANJAC, B. \& MARAMOROSCH, K. Electron microscopy of the xylem of ratoon stunted sugarcane. Phytopathology, 65(5):498-9, 1972.

RICAUD C. Problems in the diagnosis of ratoon stunting disease. Proceedings of the International Society of Sugar Cane Technologists, 15:241-8, 1974.

ROACH, B.T. Susceptibility to ratoon stunting disease in the Saccharum complex and feasibility of breeding for resistance. Sugar Cane, 3:1-11, 1992.

ROBINSON, R.A. Host managment in crop pathosystems. New York: Macmillan, 1987. $263 p$.

ROSSLER, L.A. The effects of ratoon stunting disease on three sugarcane varieties under different irrigation regimes. In: Proceedings International Society of Sugar Cane Technologists, 15:250-7, 1974.

RUAS, D.G.G.; MATSUOKA, S. \& GHELLER, A.C.A. Situação do uso do equipamento de tratamento térmico no centro-sul na safra 1985/86. Brasil Açucareiro, 105(1):13-6, 1987.

SANGUINO, A. Principais moléstias da cana-de-açúcar. In: PARANHOS, S.B. Cana-deaçúcar: cultivo e utilização. Campinas, Fundação Cargill, 1987. Cap.6, p.741-57.

SANGUINO, A. Binômio tempo $\mathrm{x}$ temperatura no controle do raquitismo da soqueira (RSD) da cana-de-açúcar, pelo processo de termoterapia de gemas isoladas. Cadernos Copersucar, (25): 1-5, 1989.

SANGUINO, A. Tolerância de variedades ao raquitismo da soqueira . Anais do Congresso Nacional da STAB, 5:143-7, 1993. 
SCHEFFER, R. P. \& WALKER, J. C. The physiology of Fusarium wilt of tomato Phytopathology, 43:116-25, 1953.

SCOTT, A.J. \& KNOTT, M. A cluster analysis method for grouping means in the analysis of variance. Biometrics, 30:507-12, 1974.

SILVA, W. M. Hot water treatment of single buds for ratoon stunting disease control. Sugarcane Pathologist's Newsletter, (11/12):32-3, 1974.

SIVANESAN, A. \& WALLER, J.M. Sugarcane diseases. Commonwealth Mycological Institute, Phytopathological Paper no.29. p. 73, 1986.

STEIB, R.J. Results of studies relating to the mosaic-RSD disease complex of sugarcane in Louisiana . Sugarcane Pathologist's Newsletter, 8:8-9, 1972.

STEIB, R.J. Influence of sugarcane disease tolerance on commercial planting of varieties infected with mosaic and RSD. Proceedings of the International Society of Sugar Cane Technologists, 15:1:319-326, 1974.

STEIB, R.J. \& CHILTON, S. J. P. The role of RSD in deterioration of sugarcane varieties. Sugar Journal, 30(12):10-2, 1968.

STEIB, R.J.; FORBES, I.L. \& CHILTON, S.J.P. A report on further studies on the ratoon stunting disease of sugarcane in Louisiana. Sugar Journal, 19:35-7, 1957.

STEINDL, D.R.L., Host range of the sugarcane ratoon stunting disease virus. Journal of Australian Institute of Agricultural Science, 23(3):238, 1957.

STEINDL, D. R. L. Q. 28 disease. Cane Grow. Q. Bull (Queensland), 12(4):191-3, 1949. 
STEINDL, D. R. L. Ratoon stunting disease. In: MARTIN, J.P. ; ABBOTT, E. V. ; HUGHES, C. G. eds. Sugar cane disease of the world, Amsterdam: Elsevier, 1961. v1, p. 433-59.

STEINDL, D.R.L. The use of phase contrast microscopy in the identification of ratoon stunting disease. In: Proceedings Queensland Society of Sugarcane Technologists, p.71-2, 1976.

STEINDL, D.R.L. \& TEAKLE, D.S. Recent developments in the identification of ratoon stunting disease. In: Proceedings Queensland Society of Sugarcane Technologists, p.101-4, 1974.

SUITIC, D. \& SINCLAIR, J. B. Anatomy and physiology of diseased plants. Boca Raton: CRC Press, 1991, p. 232.

TALOYS, P.M. Water deficits in vascular disease. In: KOZLOWSKI, T.T. ed. Water deficits and plant growth. New York: Academic Press, v.2, p.255-331, 1968.

TAYLOR, P.W.J.; RYAN, C.C. \& BIRCH, R.G. Harvester transmission of leaf scald and ratoon stunting disease. Sugar Cane, 4:11-4, 1988.

TEAKLE, D.S. The sugarcane ratoon stunting disease bacterium. In: FAHY, P.C. \& PERSLEY, G.J. (ed). Plant bacterial diseases: a diagnostic guide. North Ryde: Academic Press, 1983. Cap. 11, p.247-57.

TEAKLE, D.S.; APPLETON, J.M. \& STEINDL, D.R. An anatomical basis for resistance of sugarcane to ratoon stunting disease. Physiological Plant Pathology, 12:83-91, 1978.

TEAKLE, D.S., KONTZE, D. \& APPLETON, J.M. A note on the diagnosis of ratoon stunting disease of sugarcane by negative-stain eletron microscopy of the associated bacterium. J. Appl. Bacteriol. 46:279-84, 1979. 
TEAKLE, D.S.; SMITH, P.M. \& STEINDL, D.R.L. Association of a small coryneform bacterium with the ratoon stunting disease of sugarcane. Australian Journal of Agricultural Research, 24:869-74, 1973.

TEAKLE, D.S., SMITH, P.M., HAYWARD, A. C. \& STEINDL, D.R.L. Diagnosis of R.S.D. by electron microscopy of sugar-cane tissue diffusates. In: Proceedings Queensland Society of Sugarcane Technologists, 42:115-6, 1975a.

TEAKLE, D.S.; SMITH, P.M.; STEINDL, D.R.L. Ratoon stunting disease of sugarcane: possible correlation of resistance with vascular anatomy. Phytopathology, 65(2):138$41,1975 b$.

TOKESHI, H. Doenças da cana-de-açúcar. In: GALLI, F. (coord.). Manual de Fitopatologia. São Paulo: Agronômica Ceres, 1980. V.2, cap.12, p.141-206.

TOKESHI, H. Carvão da cana-de-açúcar (Ustilago scitaminea). Summa Phytopathologica, 9:98-110, 1983.

TOKESHI, H. Perfilhamento e perdas pelo carvão da cana-de-açúcar. Stab, p. 34-44, maio/jun. 1986.

TOKESHI, H.; GHELLER, A. C. A.; SORDI, R.A.; MASUDA, Y. \& MATSUOKA, S. Nova unidade de tratamento térmico de toletes de cana-de-açúcar para controle do raquitismo da soqueira (RSD). Summa Phytopathologica, 9: 59-61, 1983.

TOKESHI, H.; BERTOLOTI, S. G.; WAGNER, R.; BORTOLETTO, A. A. \& INNOCENTE Jr., L. A. Avaliação de perdas pelo carvão da cana-de-açúcar. In: Coleção Sopral, número 15, São Paulo: 26 p. 1987. 
TOKESHI, H.; SANGUINO, A. \& AKIBA, F. Xanthomonas albilineans, provável agente causal de raquitismo da soqueira e escaldadura da cana-de-açúcar. Brasil Açucareiro, 84(6):28-40, 1974.

VAADIA, Y. ; RANEY, F. C. \& HAGAN, R. M. Plant water deficits and physiological process. Annual Review of Phytopathology, 12:265-92, 1961.

VALARINI, P.J. Avaliação da resistência ao raquitismo da soqueira pelo método da vazão de água em colmos de cana-de-açúcar. Piracicaba, 1978. 78p. Dissertação (Mestrado) - Escola Superior de Agricultura "Luiz de Queiroz”, Universidade de São Paulo.

VALARINI, P.J. \& TOKESHI, H. Factors that interfere in evaluation of ratoon stunting disease resistance by water flow in sugarcane stalks. Summa Phytopathologica, 7(3/4):51-6, 1981.

VANDERMOLEN, G.E.; BECKMAN, C.H. \& RODEHORST, E. Vascular gelation: a general response phenomenon following infection. Physiol. Plant Pathol., 11:95-100, 1977.

VANDERPLANK, J.E. Plant diseases: epidemic and control. New York: Academic Press, 1963. 349p.

VANDERPLANK, J.E. Disease resistance in plants. 2ed, Orlando: Academic Press, 1984.

VEIGA, F. M. Notas sobre o raquitismo das socas em campos. Brasil Açucareiro, $47(1): 81-3,1956$.

WANG, C.S. Relationship between some environmental factors and cane yield with ratoon stunting disease. 2. Fertilizer and soil moisture content. Rep. Taiwan Sugar Exp. Sta., 38:81-9, 1966. 
WEHLBURG, C. Ratoon stunting disease in Cuba. Sugar Journal, 51(3):27-9, 1956.

WEAVER, L. ; TEAKLE, D.S. \& HAYWARD, A.C. Ultrastructural studies on the bacterium associated with the ratoon stunting disease of sugarcane. Australian Journal of Agricultural Research, 28:843-52, 1977,

WISMER, C.A., A sugarcane clone apparently immune to RSD. Sugarcane Pathologist's Newsletter, 6:46, 1971.

WORLEY, J.F. \& GILLASPIE Jr., A.G. Electron microscopy in situ of the bacterium associated with ratoon stuting disease in sudangrass. Phytopathology, 65:287-95, 1975

YOUNG, J.M., TOKIKAWA, Y.; GARDAN, L. \& STEAD, D.E. Changing concepts in the taxonomy of plant pathogenic bacteria. Annual Review of Phytopathology, 30:67-105, 1992.

ZADOKS, J.C. \& SCHEIN, R.D. Epidemiology and plant disease management. Oxford, Oxford University Press, 1979. 427p. 
ANEXO: Figuras e tabelas 


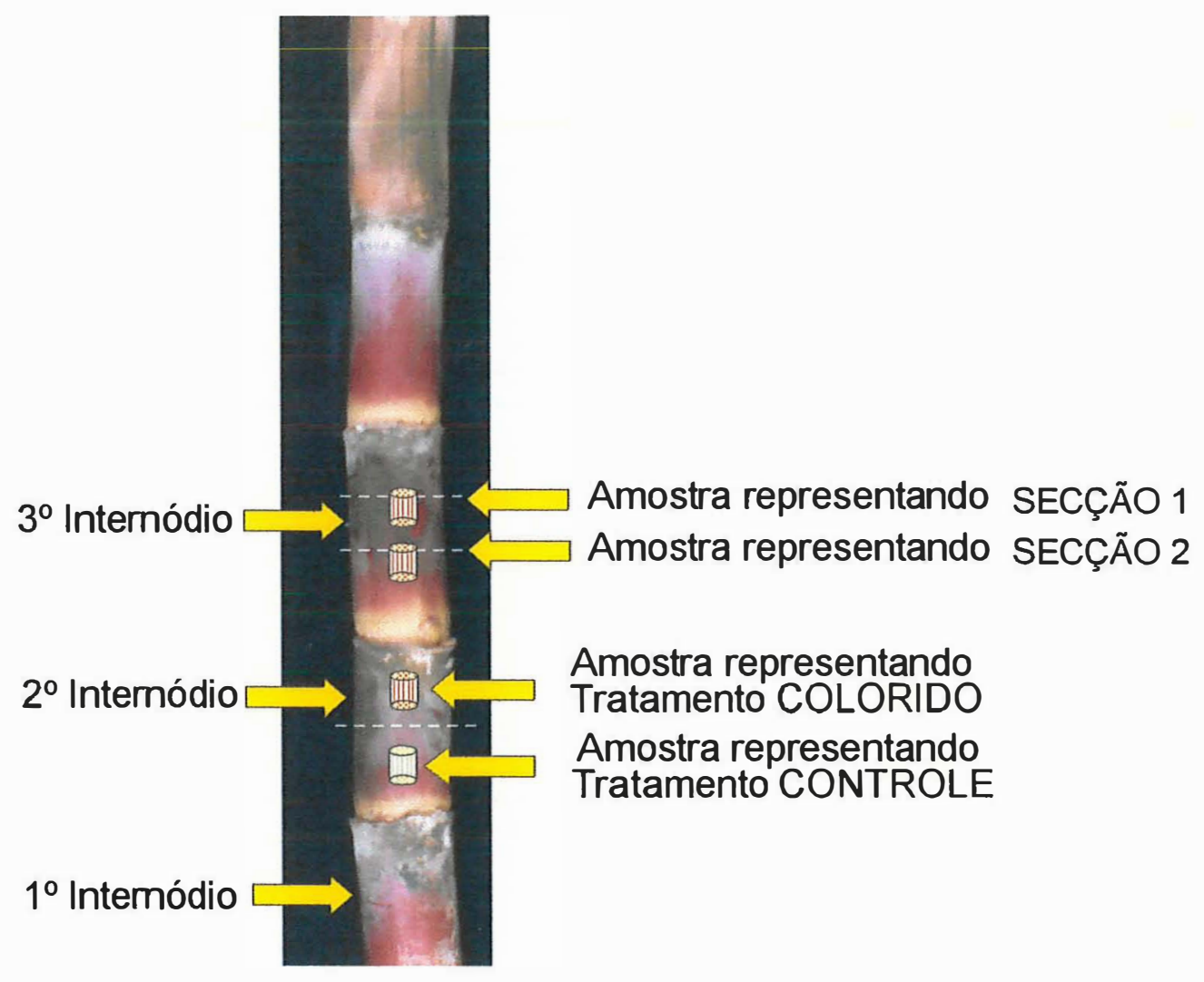

a) Colmo de cana-de-açúcar

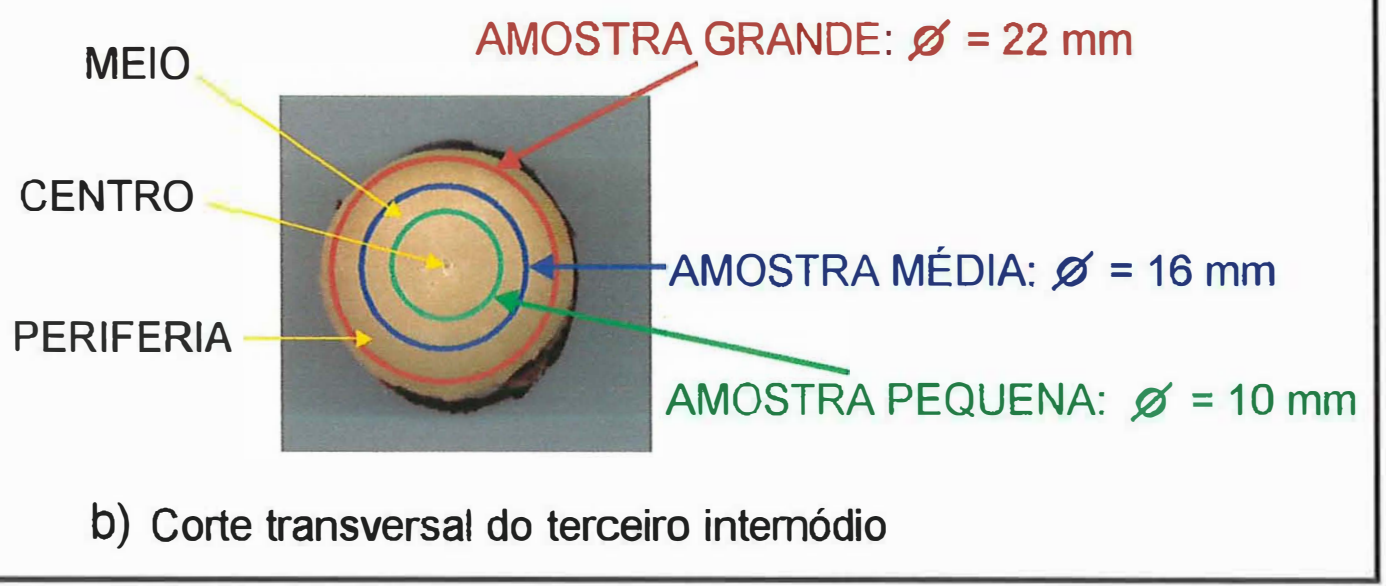

Figura 1. Representação esquemática de colmos de cana-de-açúcar ilustrando diferentes tipos de amostras (a: colmo de cana de açúcar; b: seç̧ão transversal do terceiro internódio). 

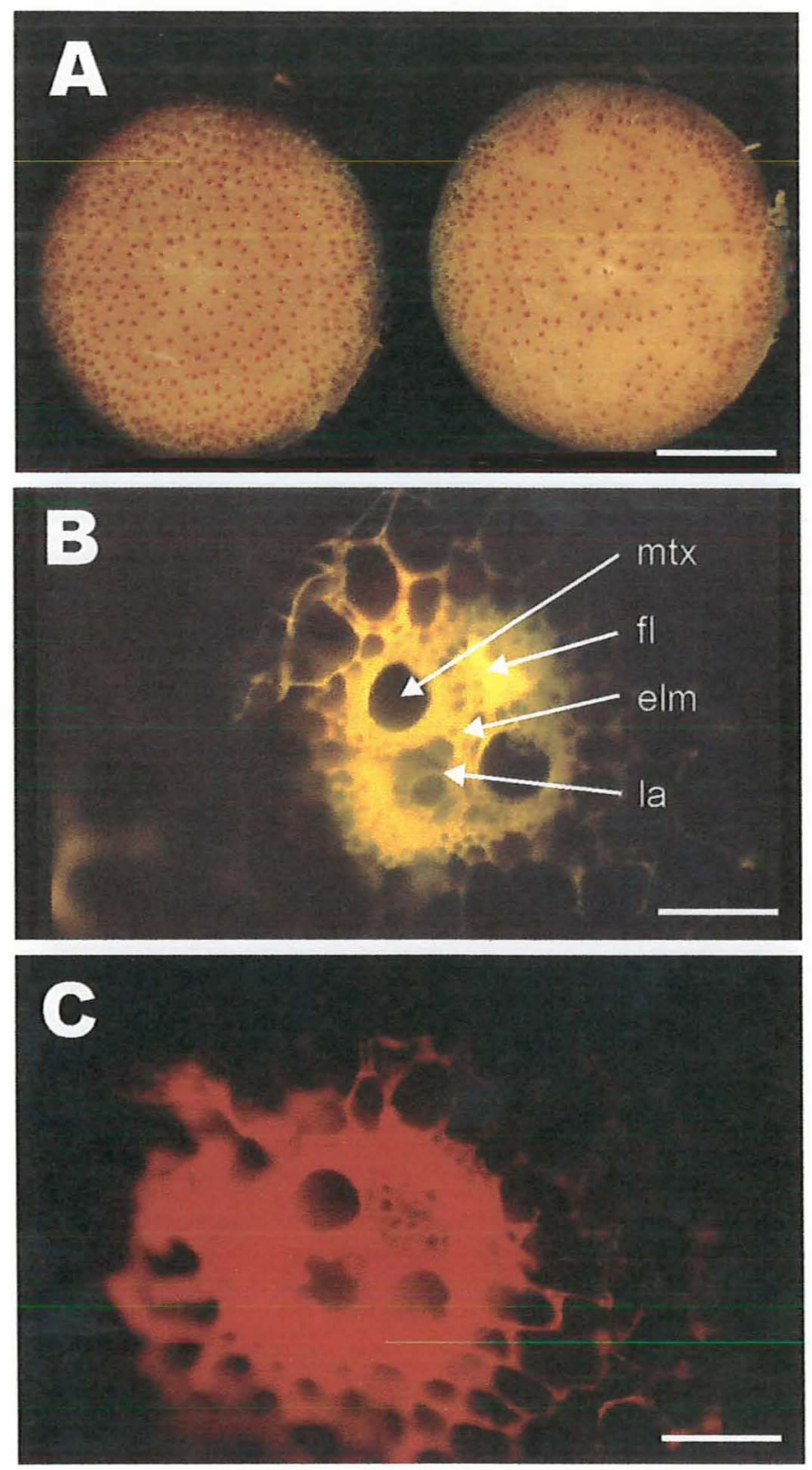

Figura 2. Deteç̧ão de feixes vasculares funcionais e entupidos por Clavibacter xyli subsp. $x y l i$ em cana-de-açúcar com Raquitismo-da-soqueira, através do Método da coloração do xilema. A, Seç̧ões transversais de colmos de cana-de-açúcar representando uma amostra sadia (esquerda) e doente (direita) (barra $=10 \mathrm{~mm}$ ). B, Seç̧ão transversal de um feixe vascular entupido por C.x. subsp. $x y l i$, quando observado ao microscópio de epifluorescência $($ barra $=200 \mu \mathrm{m}, \mathrm{mtx}=$ metaxilema, elm $=$ elementos do metaxilena, $\mathrm{fl}=$ floema, la= lacuna). $\mathbf{C}$, Seç̧ão transversal de um feixe vascular funcional colorido por solução de safranina O $($ barra $=200 \mu \mathrm{m})$. 


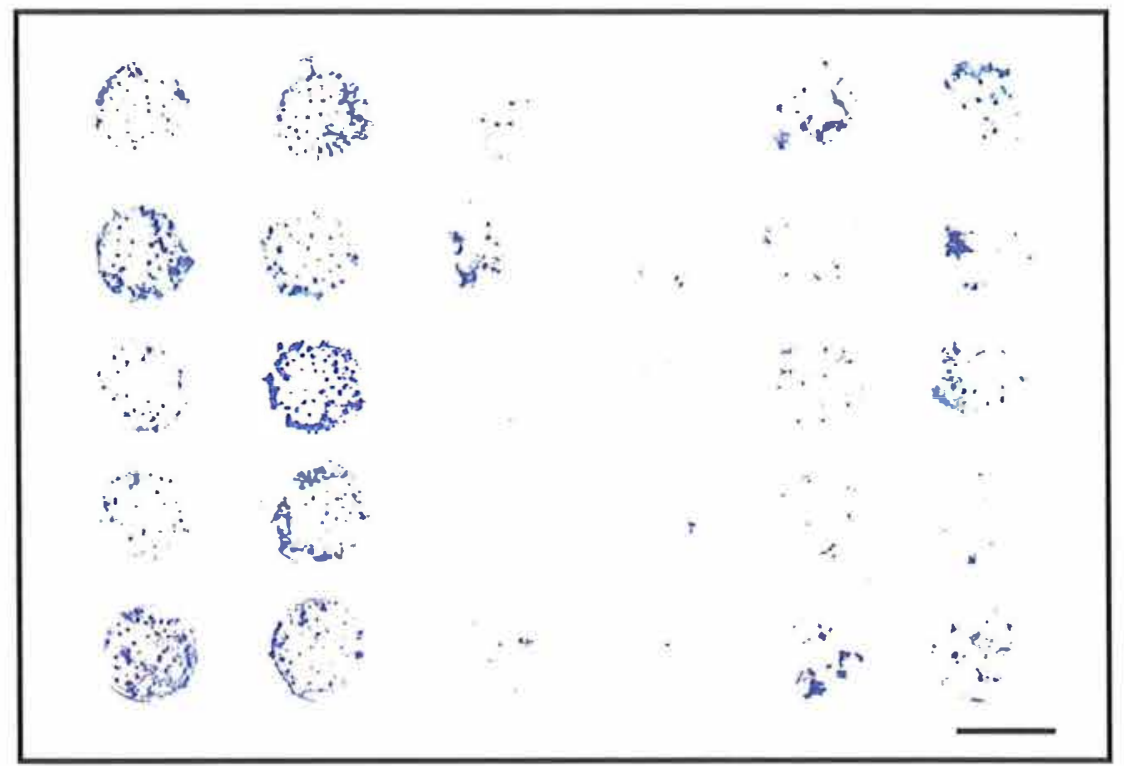

Figura 3. Membrana de nitrocelulose ( 30 amostras) ilustrando a detecção de feixes vasculares colonizados por Clavibacter xyli subsp. xyli $($ barra $=10 \mathrm{~mm})$, através do TBIA. 


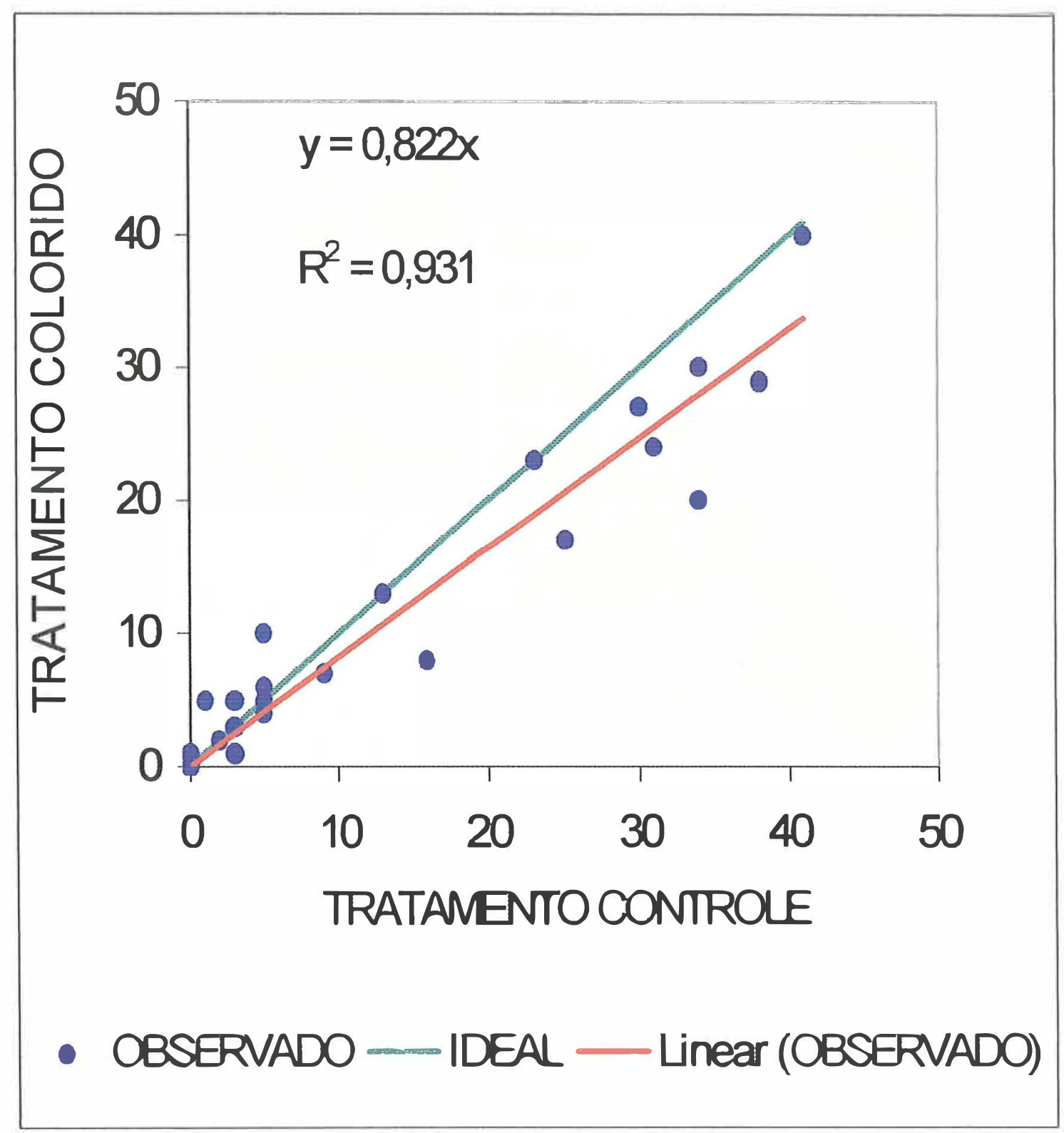

Figura 4. Relação entre a média de feixes vasculares de colmos de cana-de-açúcar colonizados por Clavibacter xyli subsp. xyli em membranas do tratamento CONTROLE (sem safranina $\mathrm{O}$ ) e do COLORIDO (manchadas com safranina $\mathrm{O}$ ). 

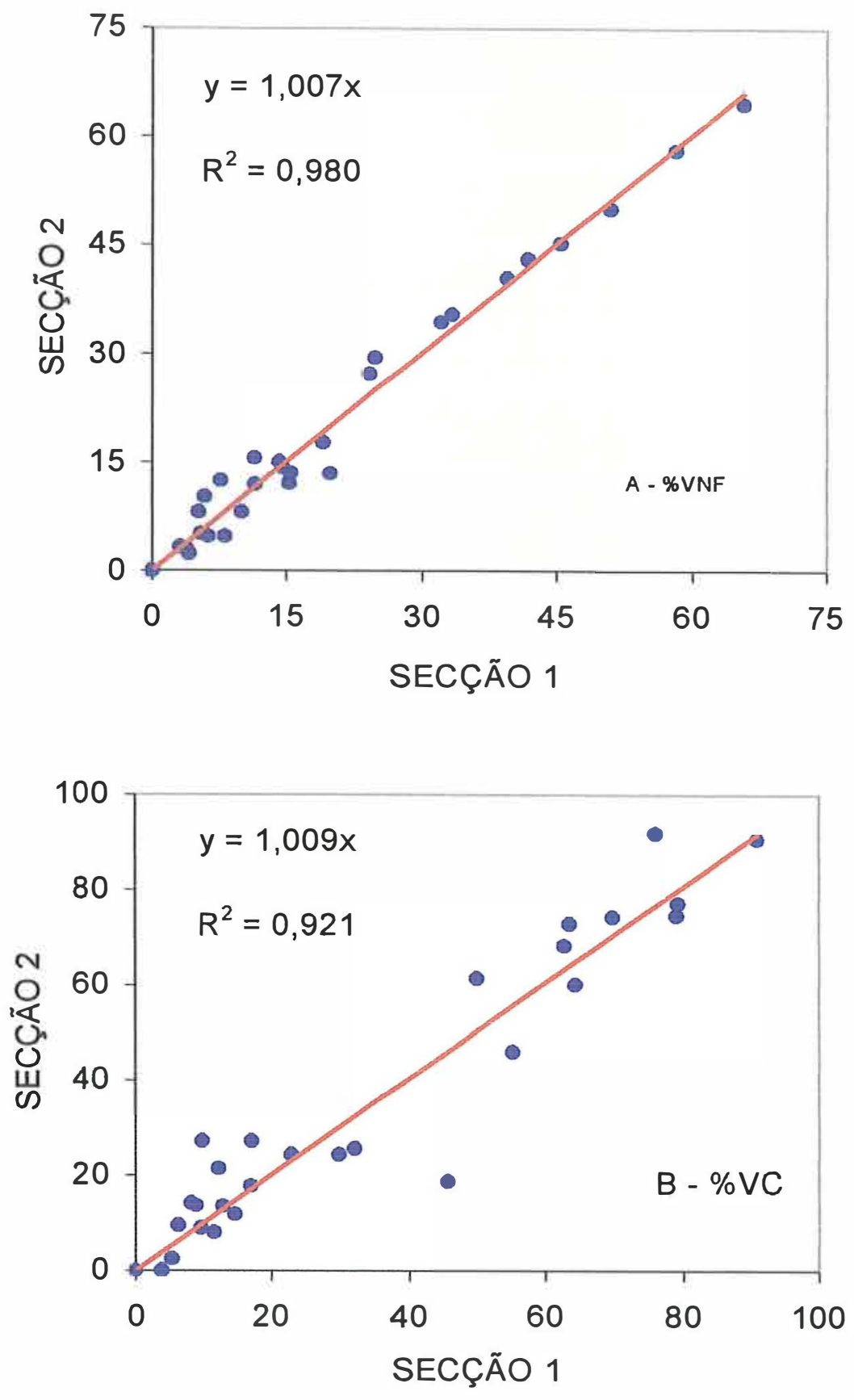

- OBSERVADO — Linear (OBSERVADO)

Figura 5. Regressões lineares entre a severidade do RSD estimada na SECÇÃO 1 e SECÇÃO 2 (A - porcentagem de vasos não funcionais = \%VNF; B - porcentagem de vasos colonizados $=\% \mathrm{VC}$ ) 

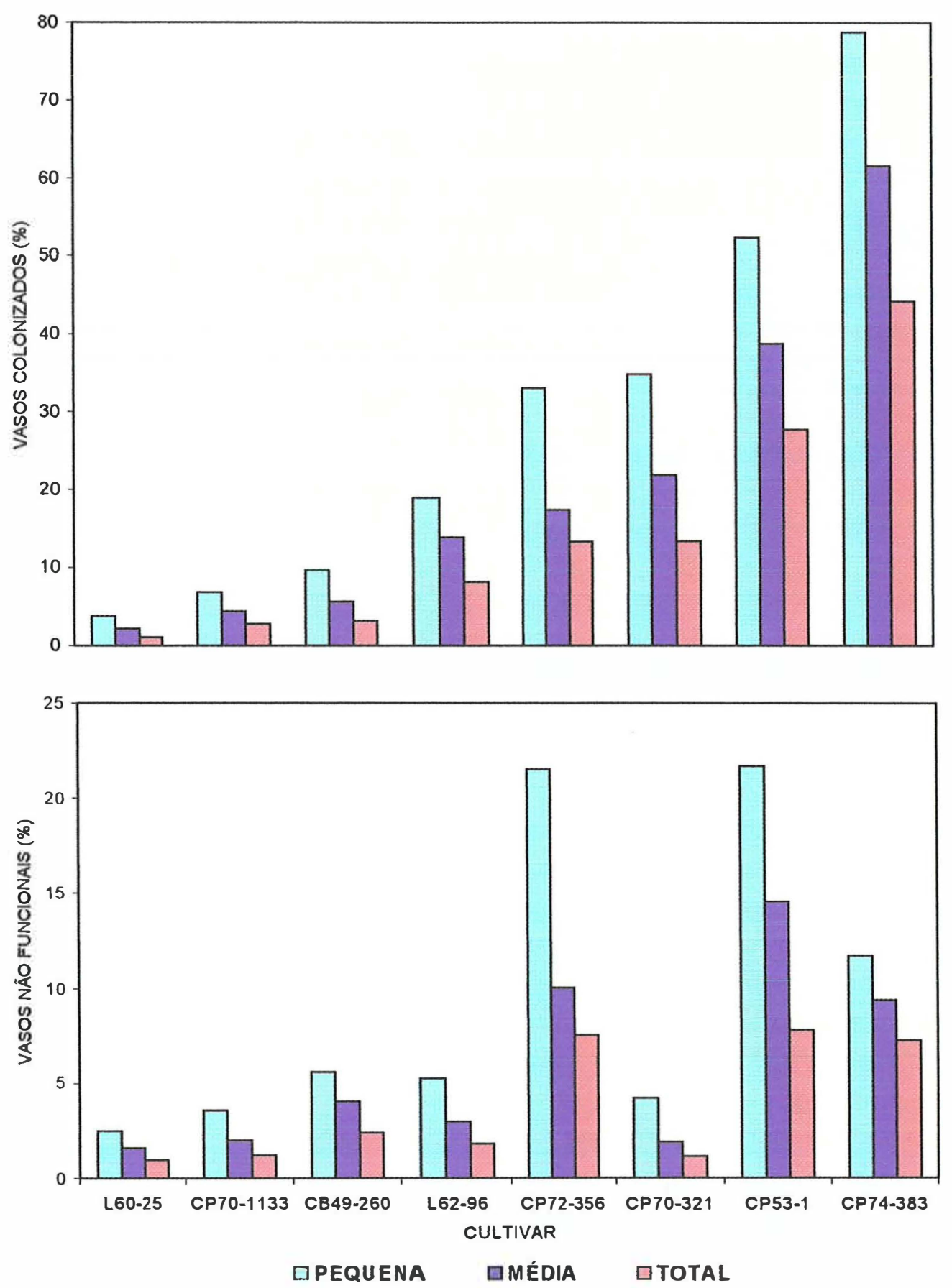

Figura 6. Porcentagem de vasos colonizados e não funcionais nas amostras PEQUENA $\left(0,789 \mathrm{~cm}^{2}\right)$, MÉDIA $\left(2,010 \mathrm{~cm}^{2}\right)$ e GRANDE $\left(3,399 \mathrm{~cm}^{2}\right)$ retiradas do centro de secções transversais do terceiro internódio de colmos de cana-de-açúcar (média de 10 colmos para cada cultivar). 

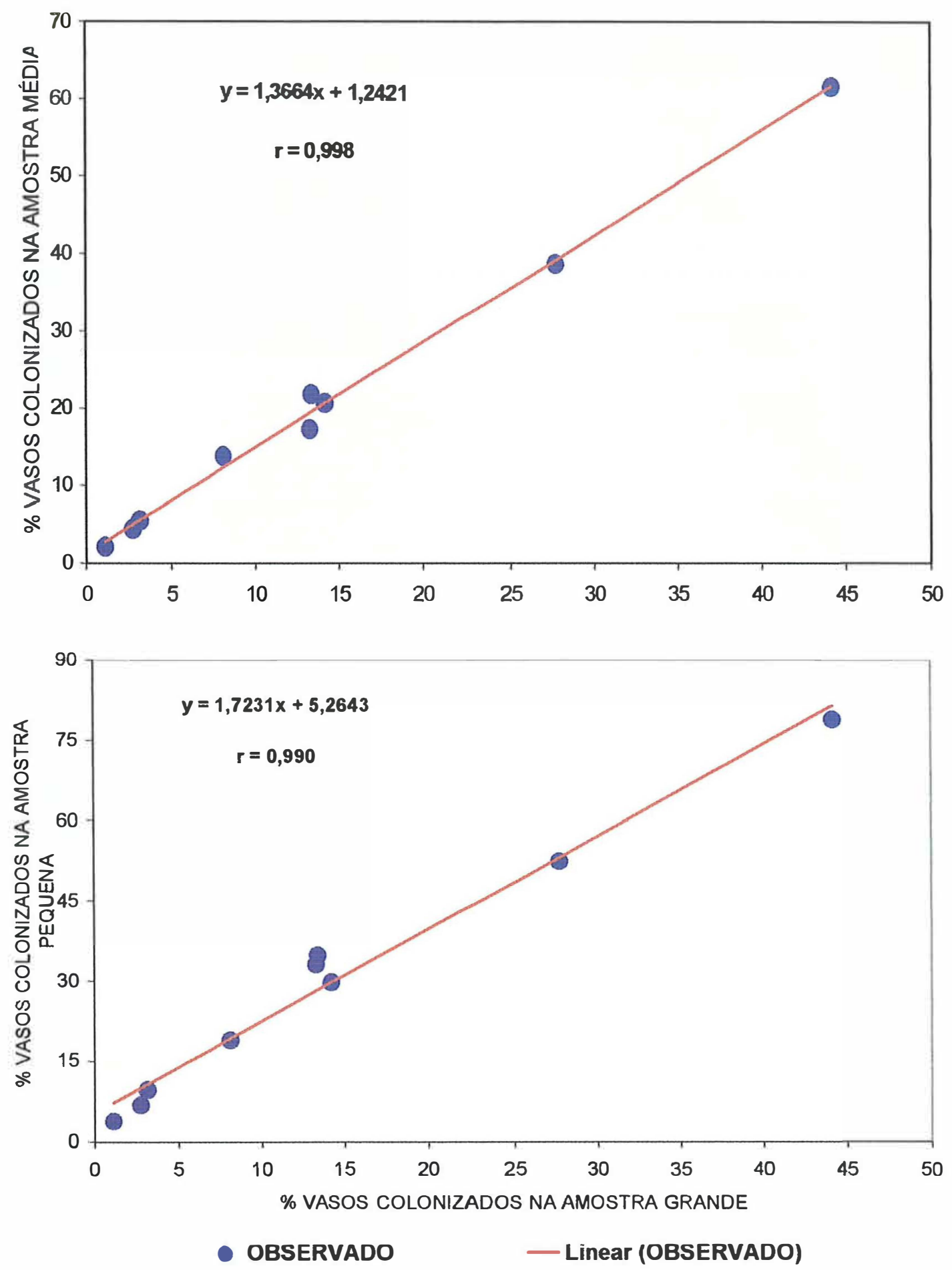

Figura 7. Regressões lineares e correlações entre a porcentagem de vasos colonizados por $C$. $x$. subsp. $x y l i$ em amostras reduzidas (PEQUENA e MÉDIA) e GRANDE para oito cultivares de cana-de-açúcar, sendo cada um representado pela média de 10 colmos. 

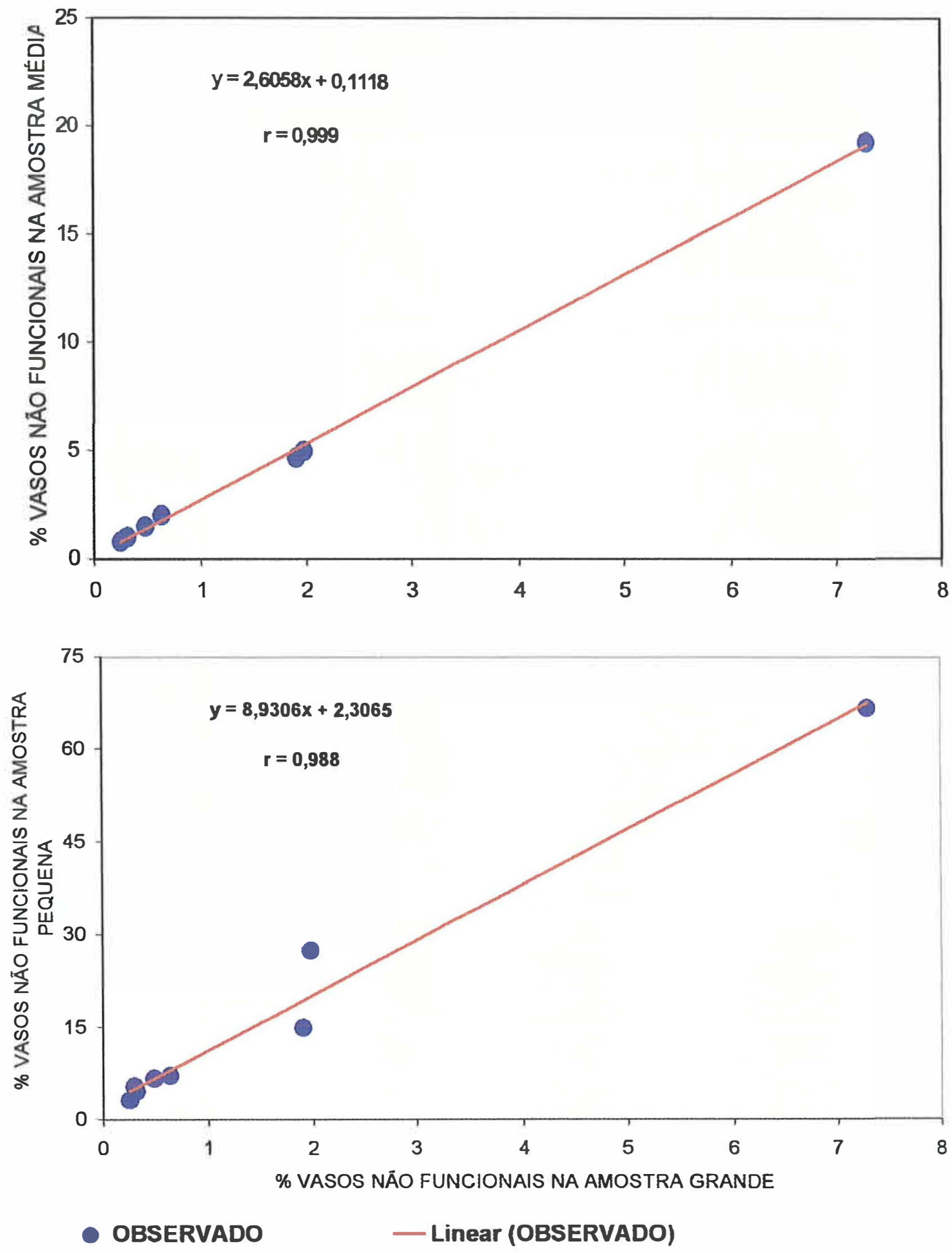

Figura 8. Regressões lineares e correlações entre a porcentagem de vasos não funcionais em amostras reduzidas (PEQUENA E MÉDIA) e GRANDE para oito cultivares de cana-de-açúcar, sendo cada um representado pela média de 10 colmos. 


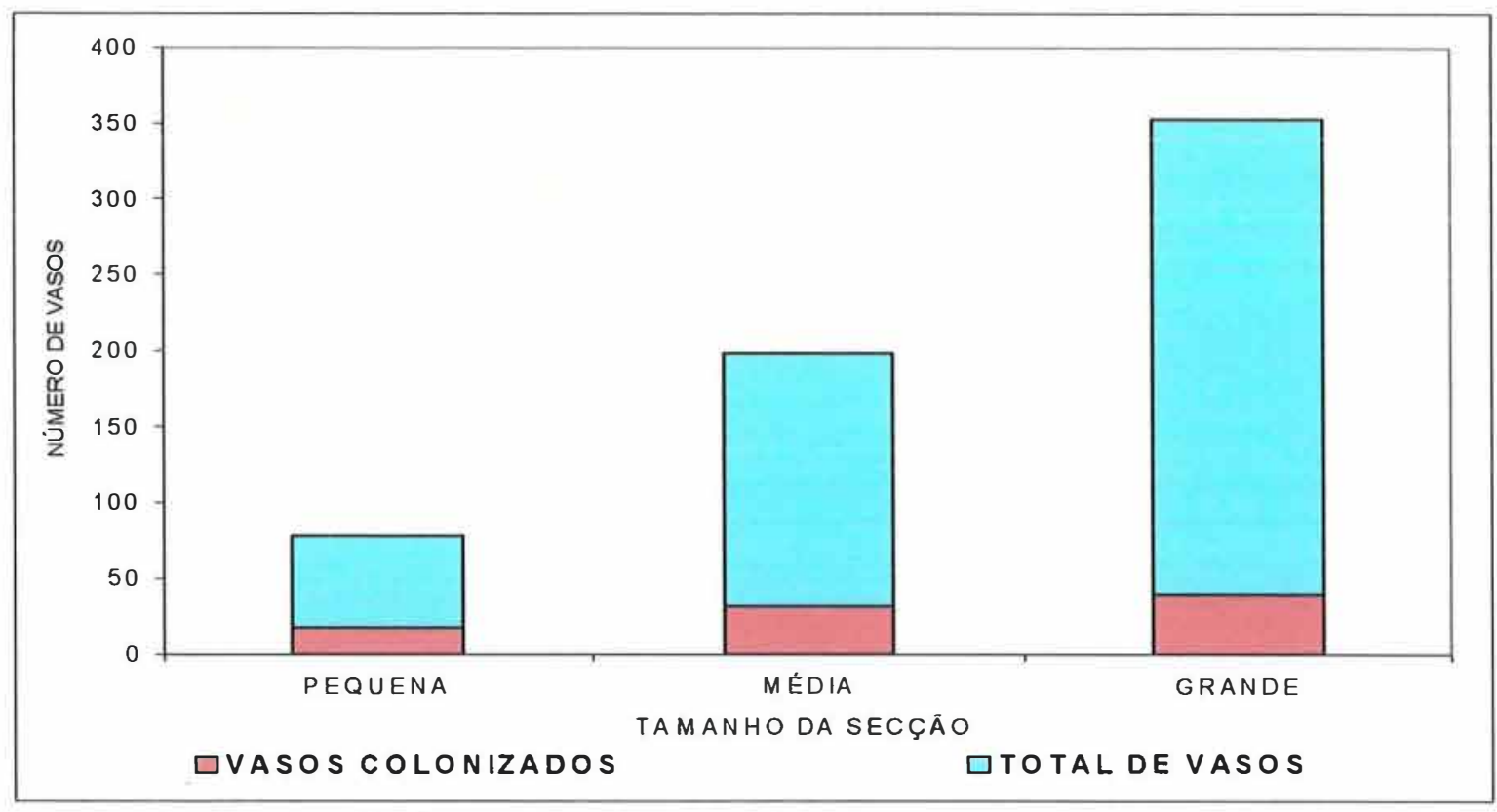

Figura 9. Vasos colonizados por $C$. $x$. subsp. xyli e total de vasos em secções transversais PEQUENA $\left(0,785 \mathrm{~cm}^{2}\right)$, MÉDIA $\left(2,010 \mathrm{~cm}^{2}\right)$ e GRANDE $\left(3,799 \mathrm{~cm}^{2}\right)$ de colmos de cana-de-açúcar (média de oito cultivares, sendo cada um representado por 10 colmos).

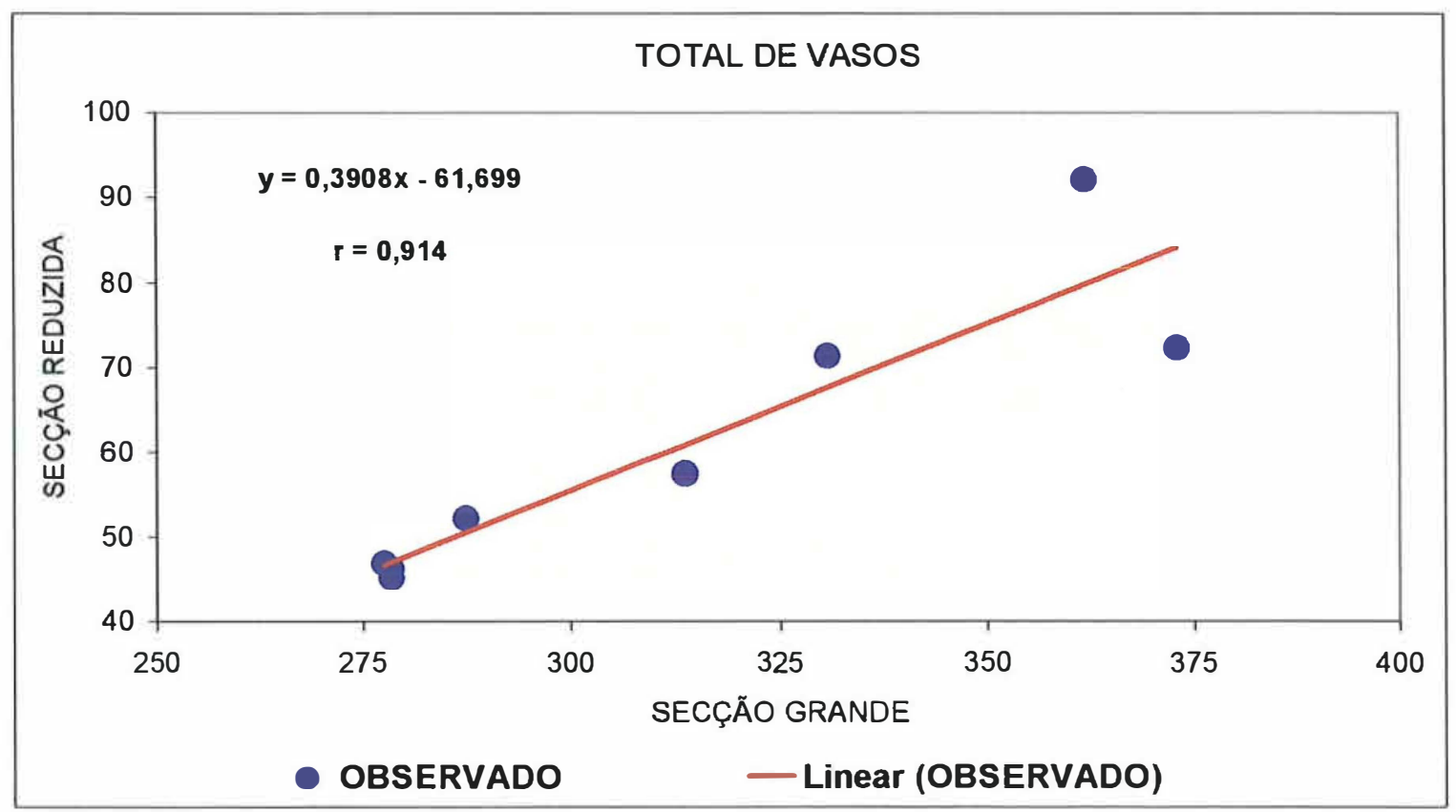

Figura 10.Regressão linear e correlação entre o númeto de feixes vasculares avaliados nas seç̧ões transversais PEQUENA e GRANDE de oito cultivares de cana-de-açúcar (média de 10 colmos para cada cultivar). 


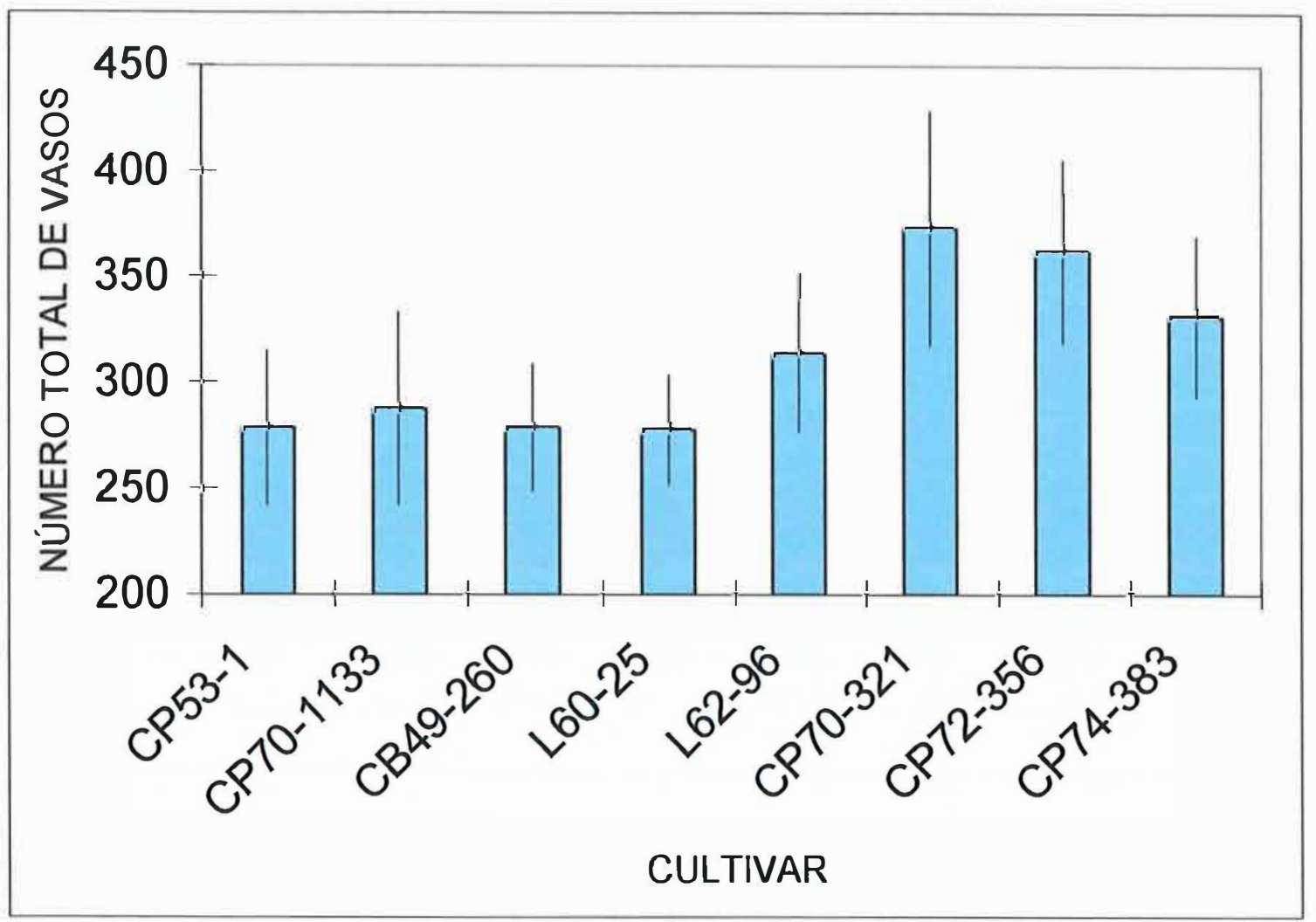

Figura 11. Número total de vasos na secção transversal da amostra GRANDE $(3,799$ $\mathrm{cm}^{2}$ ) retirada centro de colmos de oito cultivares de cana-de-açúcar (10 colmos para cada cultivar). 


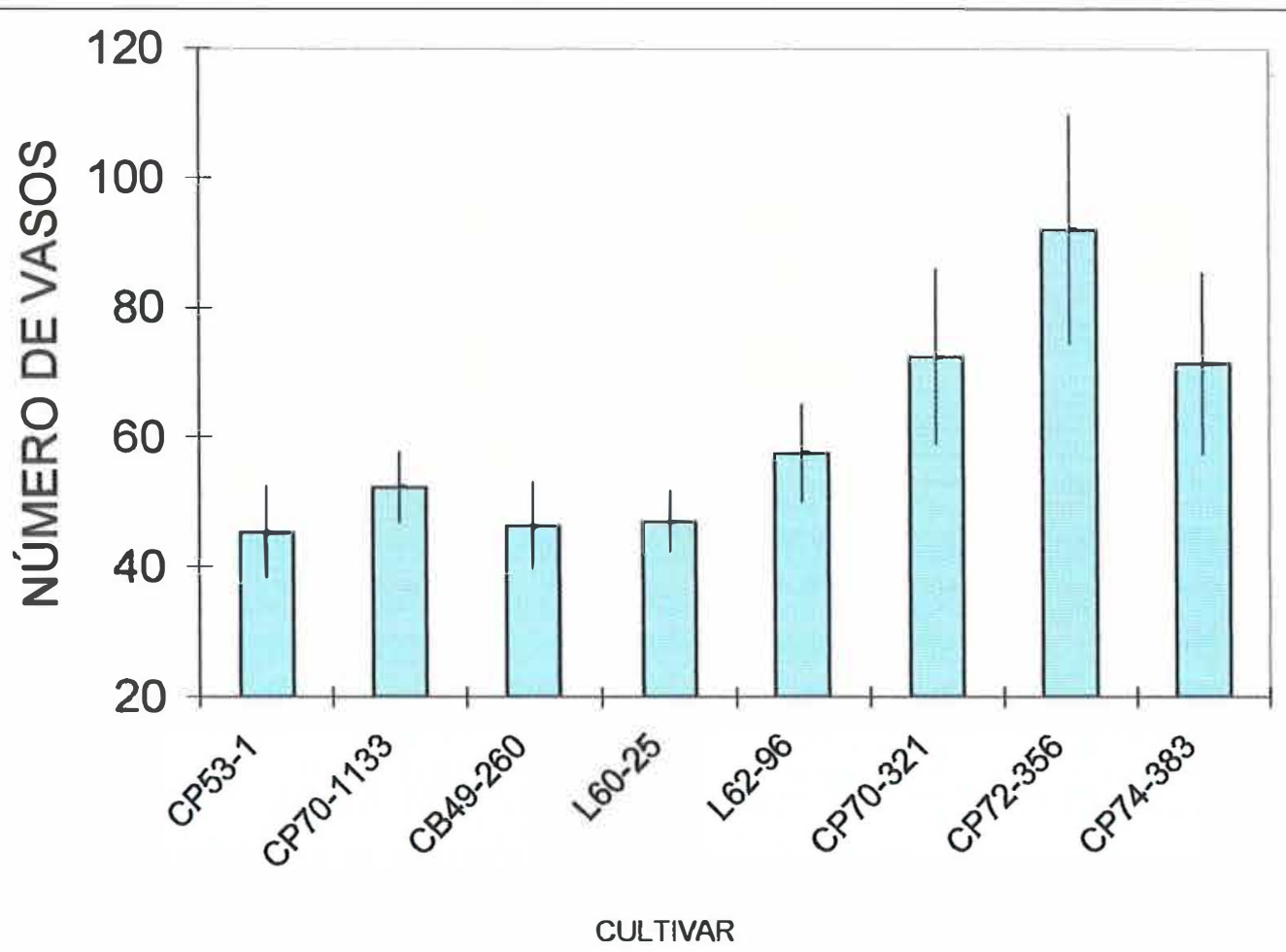

Figura 12. Número total de vasos avaliados na seç̧ão transversal PEQUENA GRANDE $\left(0,785 \mathrm{~cm}^{2}\right)$ retirada centro de colmos de oito cultivares de cana-de-açúcar (10 colmos para cada cultivar). 


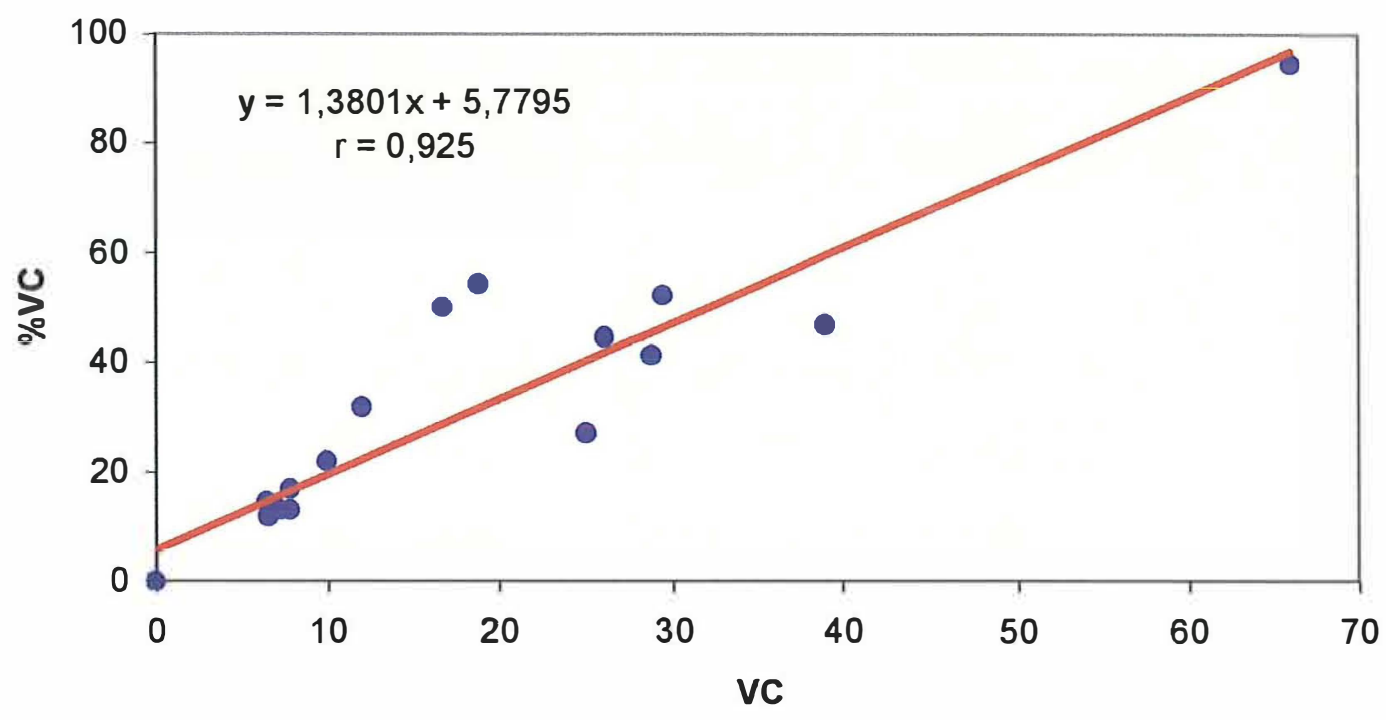

Figura 13. Regressão linear e correlação entre a porcentagem (\%VC) e o número absoluto (VC) de vasos colonizados por $C$. $x$. subsp. xyli em 19 cultivares de cana-deaçúcar, sendo cada um representado pela média de 10 colmos.

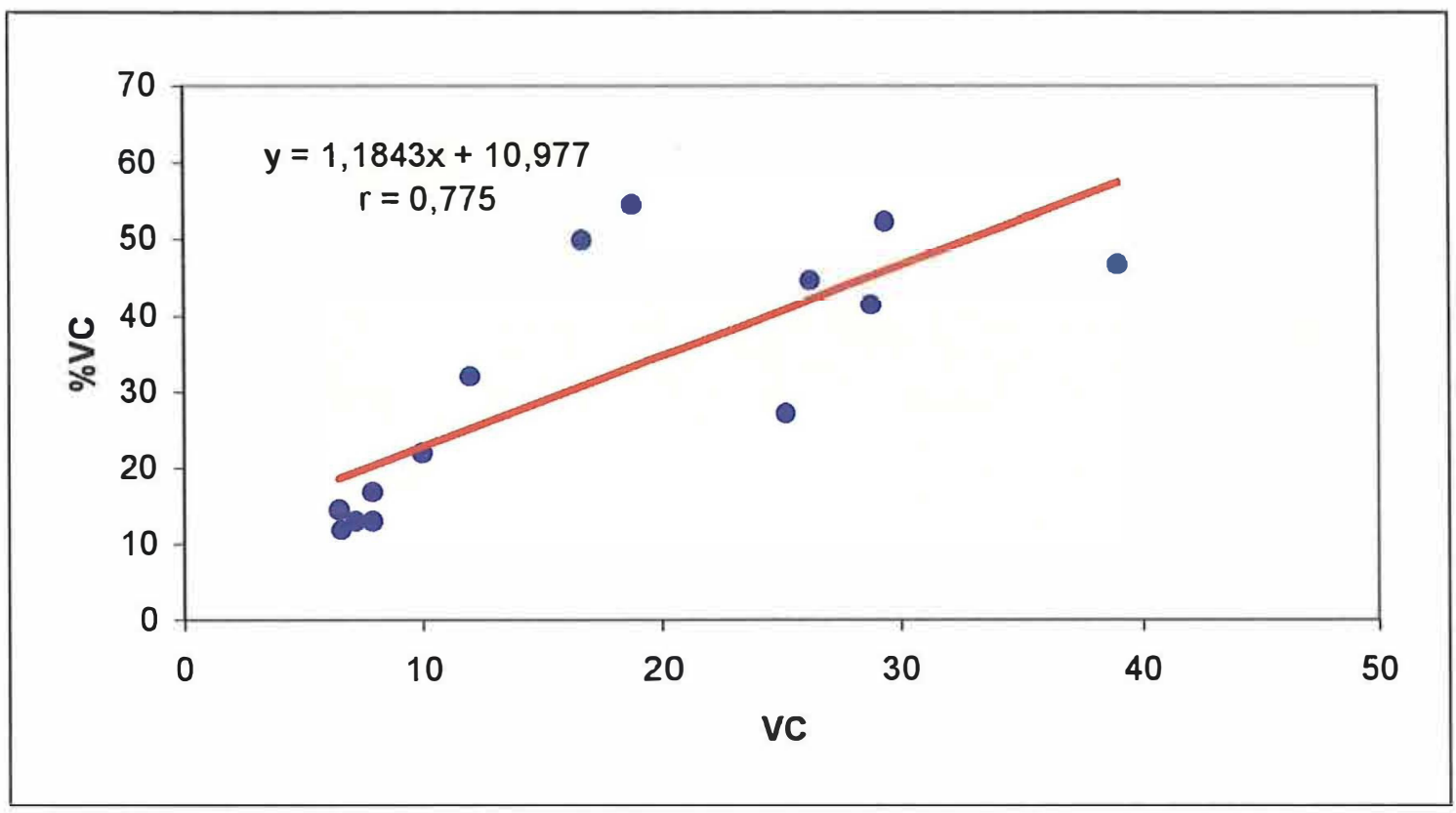

Figura 14. Regressão linear e correlação entre a porcentagem $(\% \mathrm{VC})$ e o número absoluto (VC) de vasos colonizados por $C$. $x$. subsp. xyli em 14 cultivares de cana-deaçúcar, sendo cada um representado pela média de 10 colmos. 


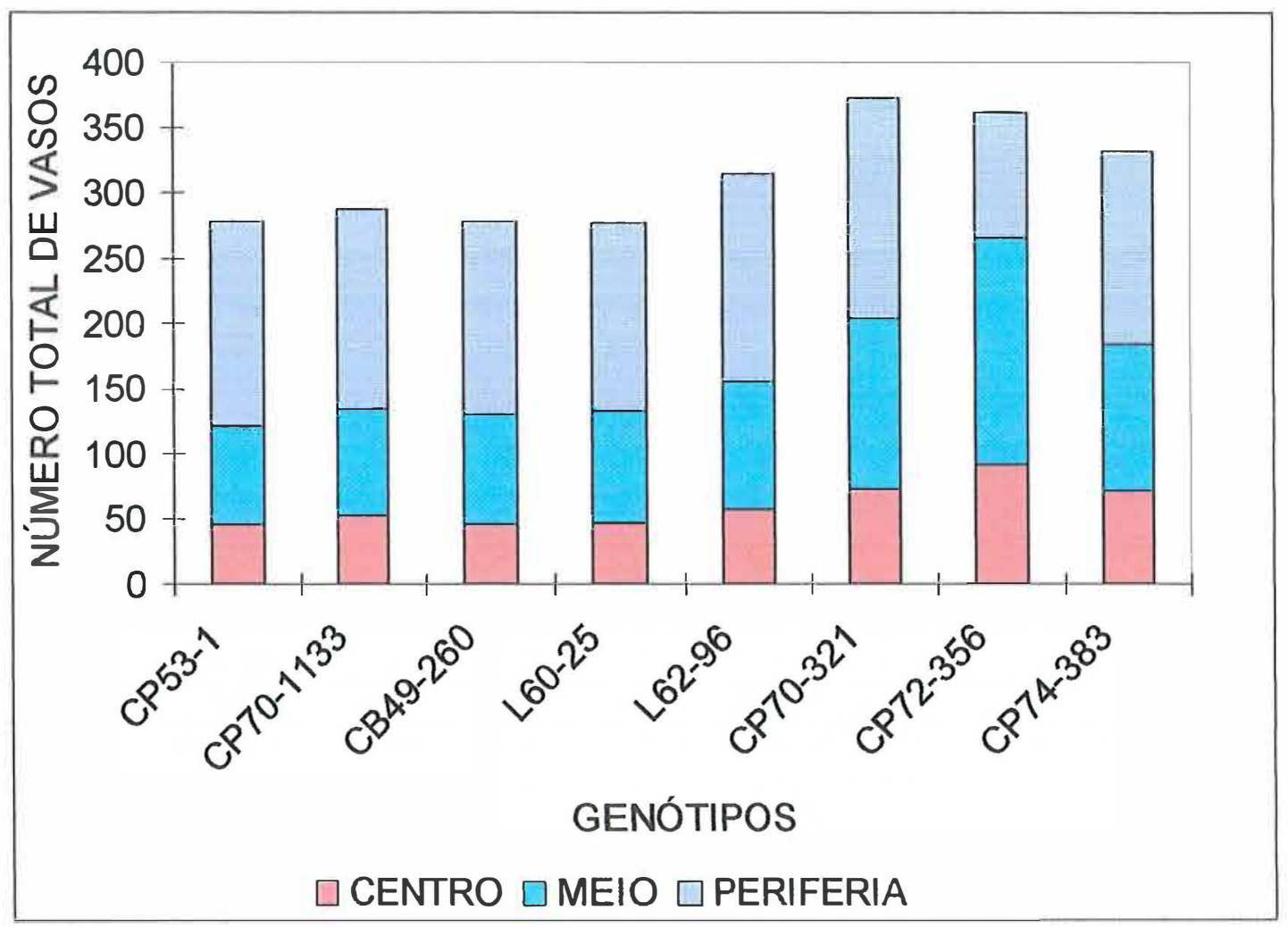

Figura 15. Distribuição de feixes vasculares em secções transversais de colmos de diferentes genótipos de cana-de-açúcar (média de 10 colmos para cada genótipo). 


\section{NÚMERO DE VASOS AMOSTRADOS}

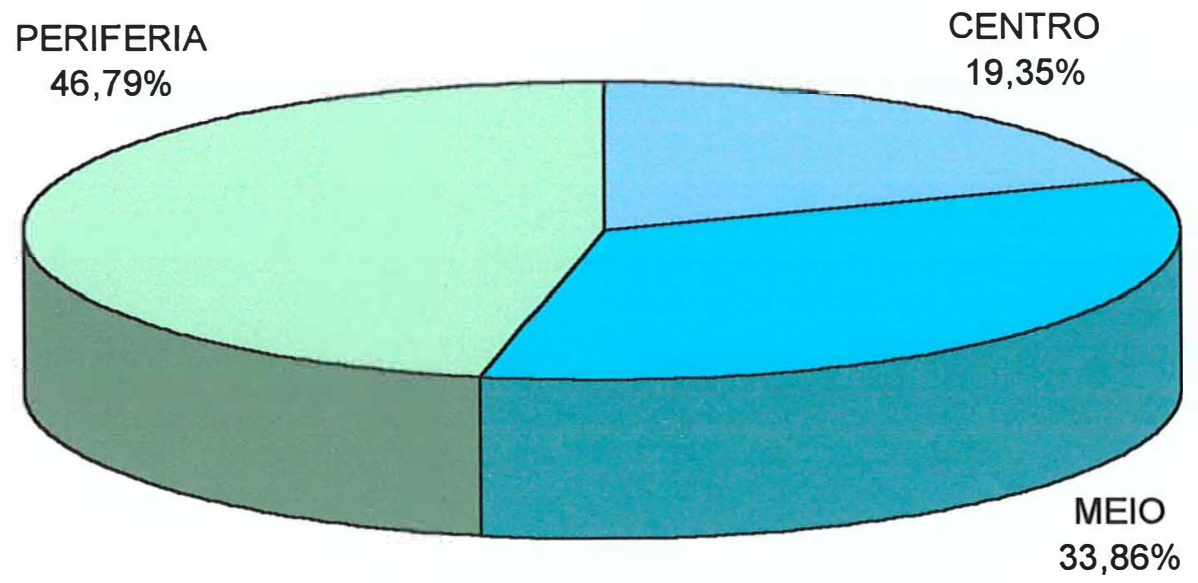

Figura 16. Distribuição de feixes vasculares no meio, centro e periferia de seç̧ões transversais de colmos de cana-de-açúcar (média de oito cultivares, sendo cada um representado por 10 colmos. 


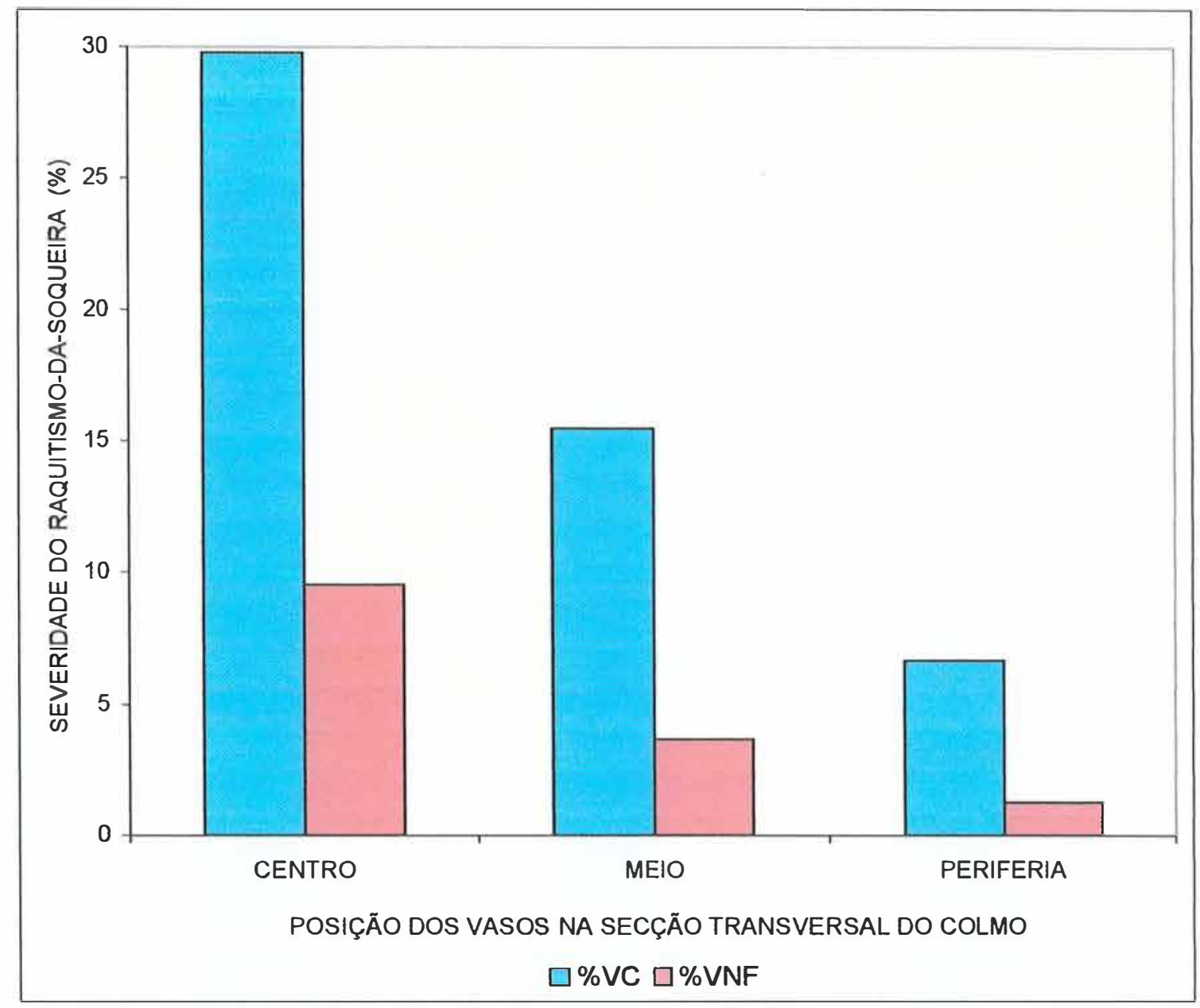

Figura 17. Distribuição de feixes vasculares colonizados por C. $x$. subsp. $x y l i$ no meio, centro e periferia de seç̧ões transversais de colmos de cana-de-açúcar (média de oito cultivares, sendo cada um representado por 10 colmos; $\% \mathrm{VC}=$ porcentagem de vasos colonizados e \%VNF = porcentagem de vasos não funcionais). 


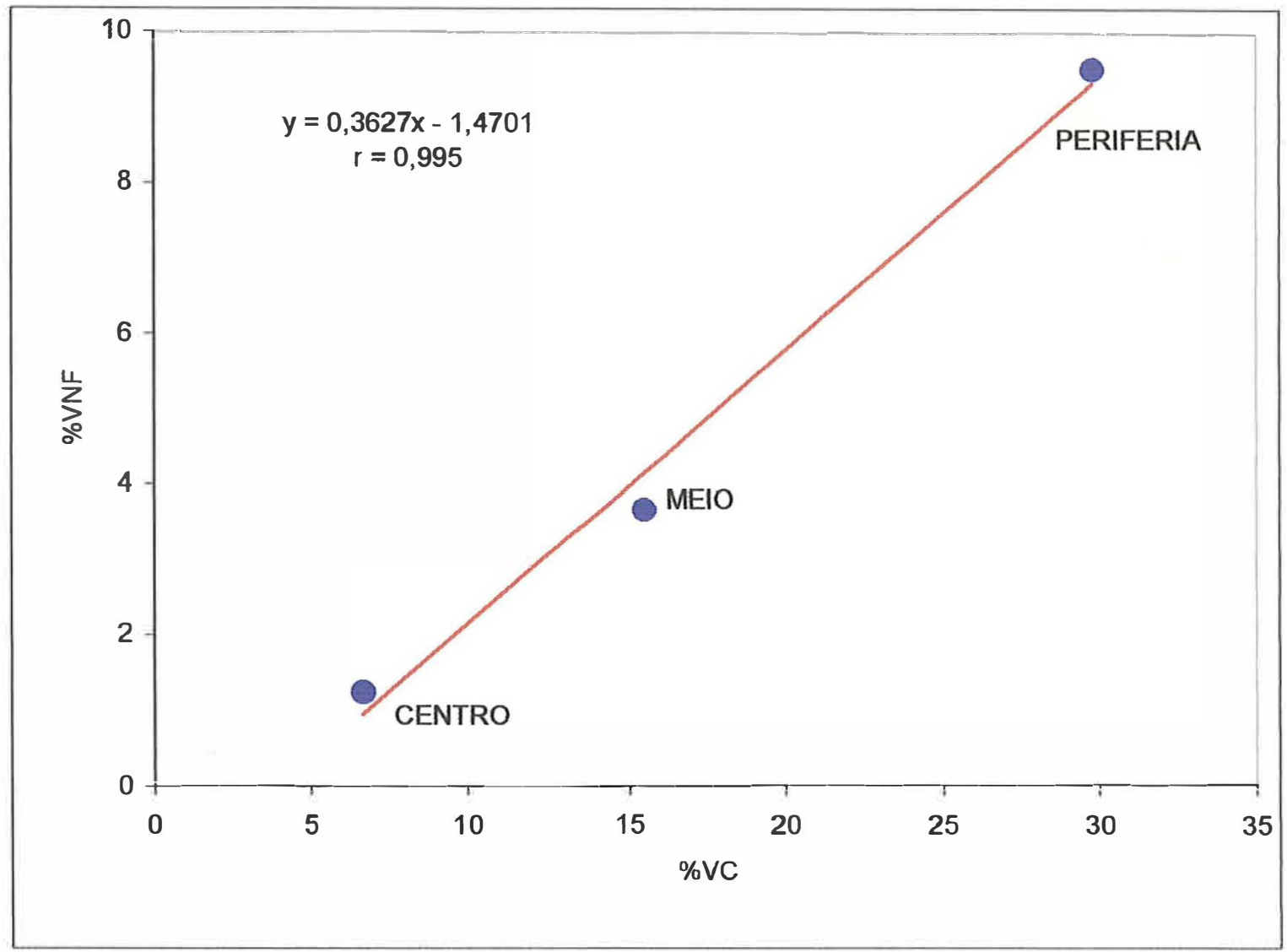

Figura 18. Relação entre porcentagem de vasos não funcionais (\%VNF) e porcentagem de vasos colonizados (\%VC) no centro, meio e periferia de seç̧ões transversais de colmos de cana-de-açúcar (média de oito cultivares, sendo cada um representado por 10 colmos). 

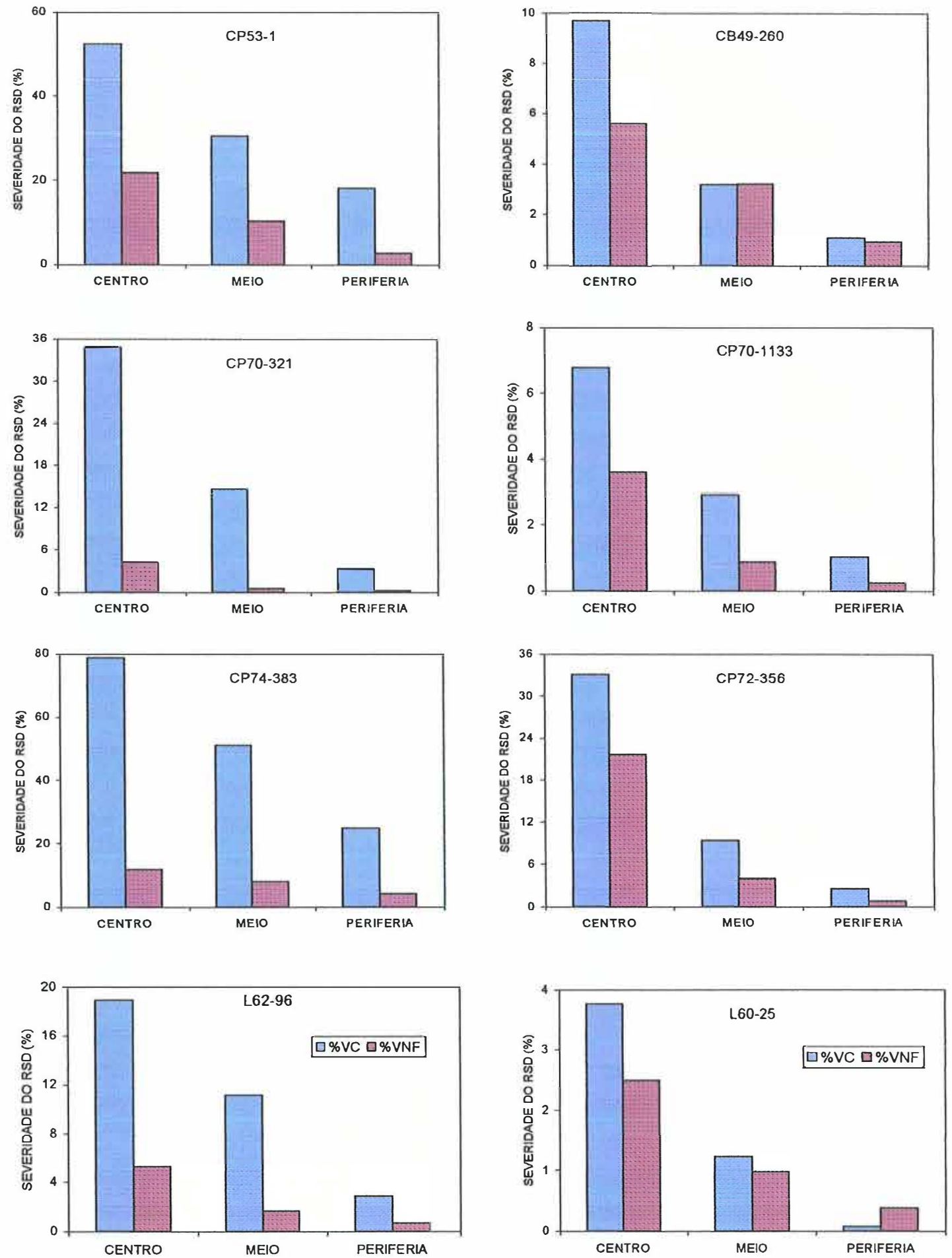

Figura 19. Padrão de colonização do xilema de colmos de oito genótipos de cana-deaçúcar por $C$. $x$. subsp. xyli $(\% \mathrm{VC}=$ porcentagem de vasos colonizados; $\% \mathrm{VNF}=$ porcentagem de vasos não funcionais). 


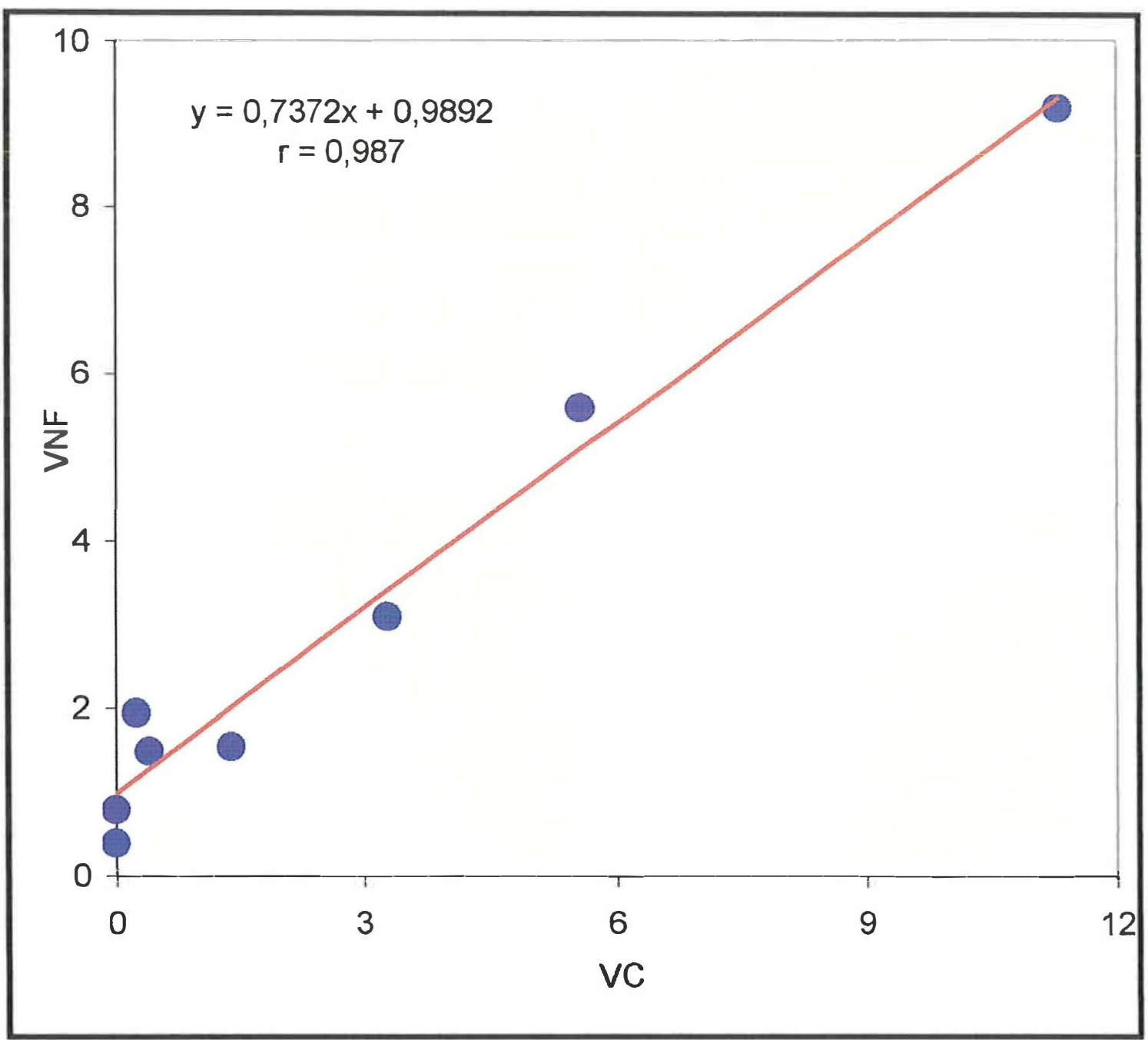

Figura 20. Relação entre o número de vasos colonizados por $C$. $x$. subsp. $x y l i$ e os respectivos vasos não funcionais em amostras do tecido central do terceiro internódio basal de colmos de nove genótipos de cana-de-açúcar moderadamente resistentes ao RSD ( $\mathrm{VNF}=$ vasos não funcionais; $\mathrm{VC}=$ vasos colonizados). 


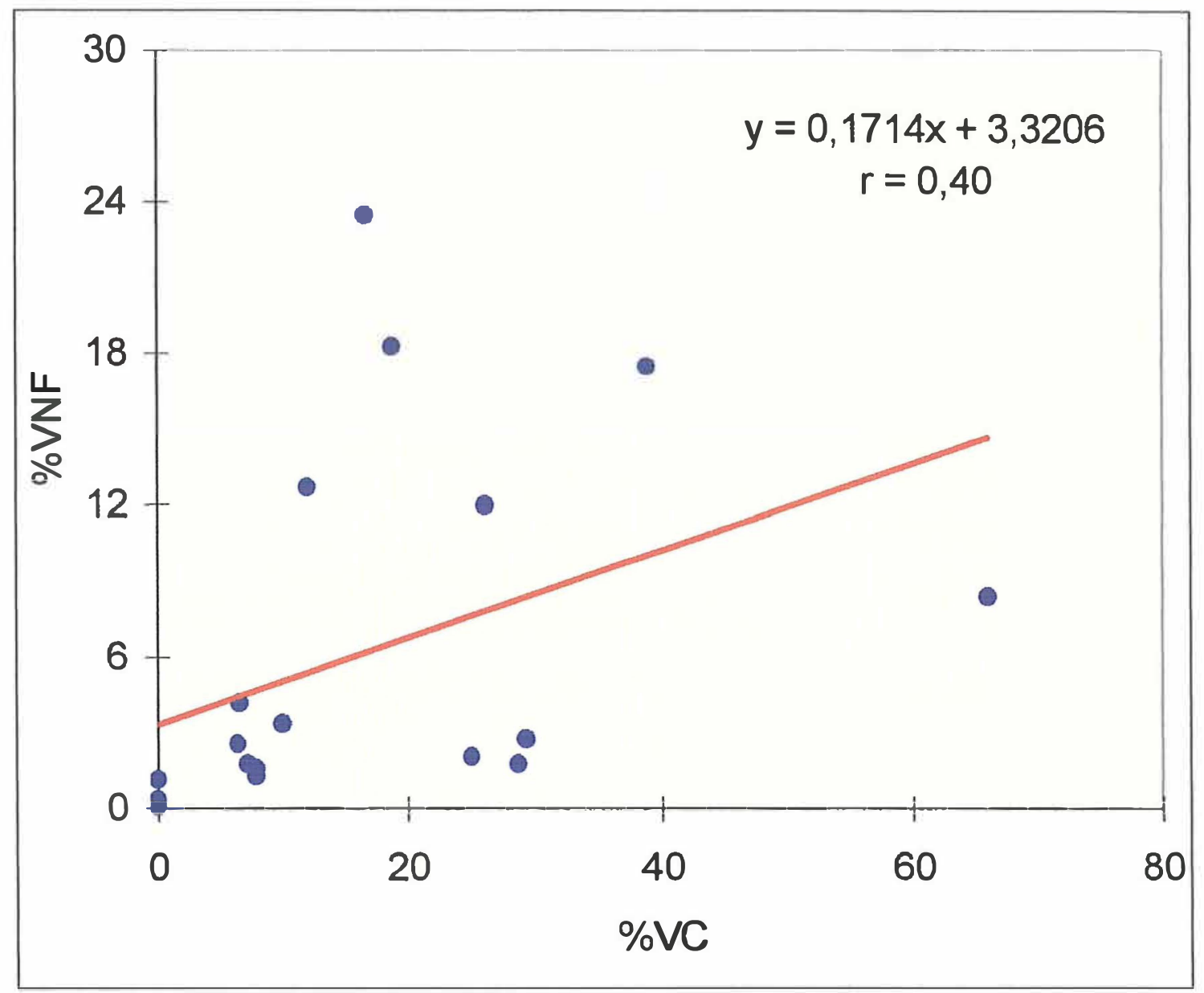

Figura 21. Relação entre a porcentagem de vasos colonizados $(\% \mathrm{VC})$ por $C$. $x$. subsp. xyli e as respectivas porcentagens de vasos não funcionais (\%VNF) em amostras do tecido central do terceiro internódio basal de colmos de 19 genótipos de cana-de-açúcar diferindo quanto ao nível de resistência ao RSD. 


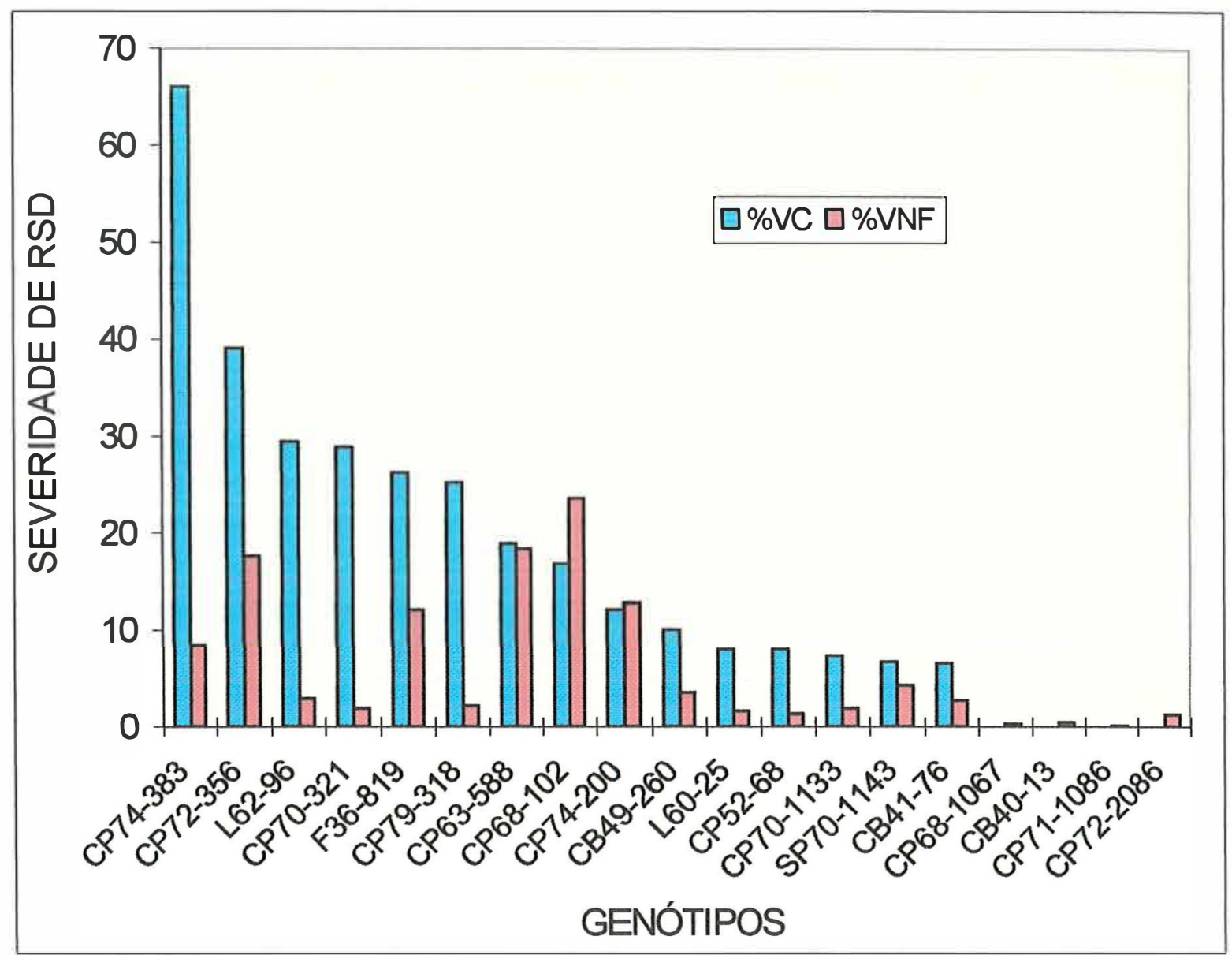

Figura 22. Porcentagem de vasos colonizados por C. $x$. subsp. xyli e as respectivas porcentagem de vasos não funcionais de 19 cultivares de cana-de-açúcar diferindo quanto à resistência ao $\mathrm{RSD}$ (média de 10 colmos para cada cultivar). 

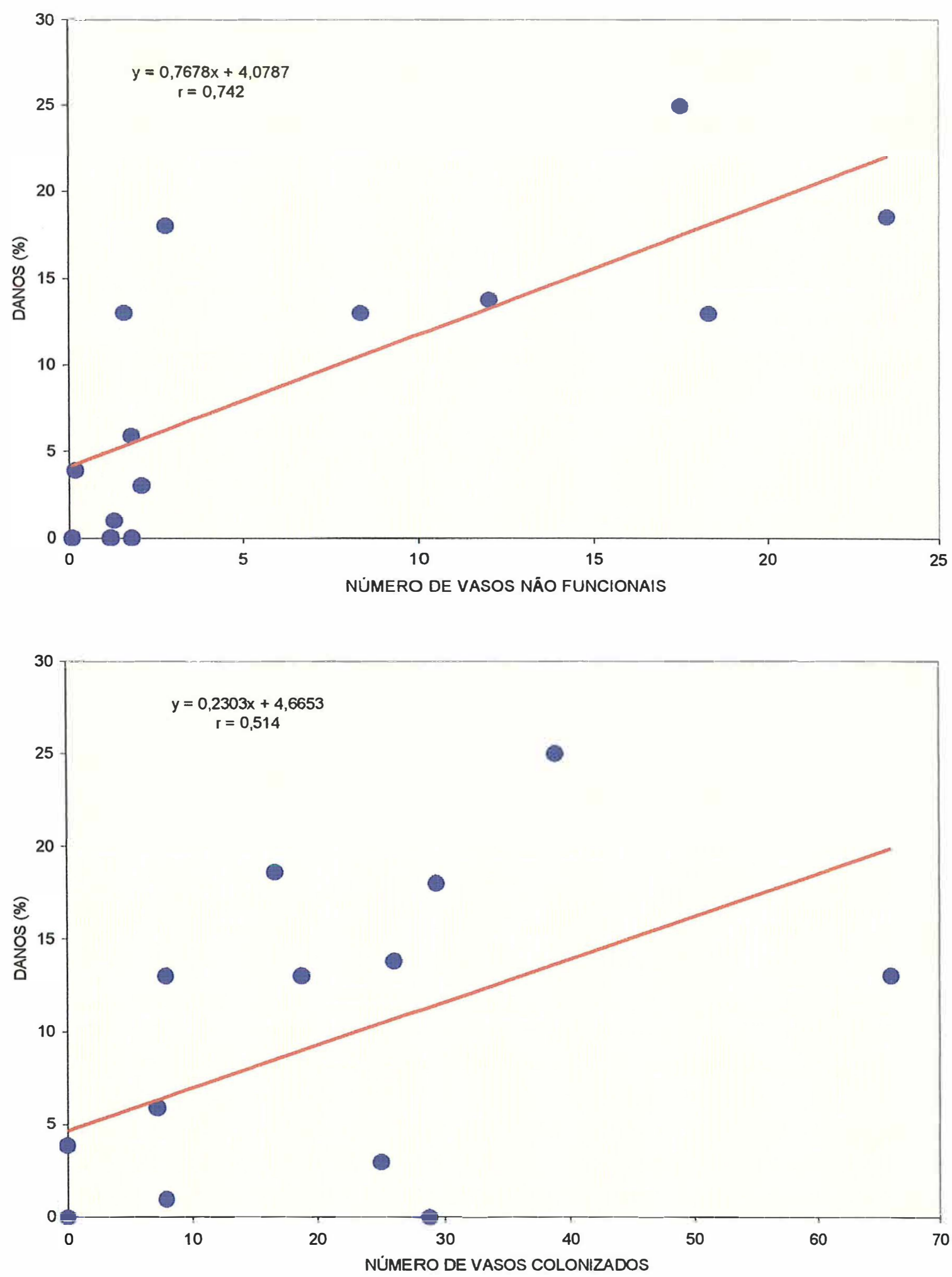

Figura 23. Relação entre severidade do RSD e danos em toneladas de cana. 


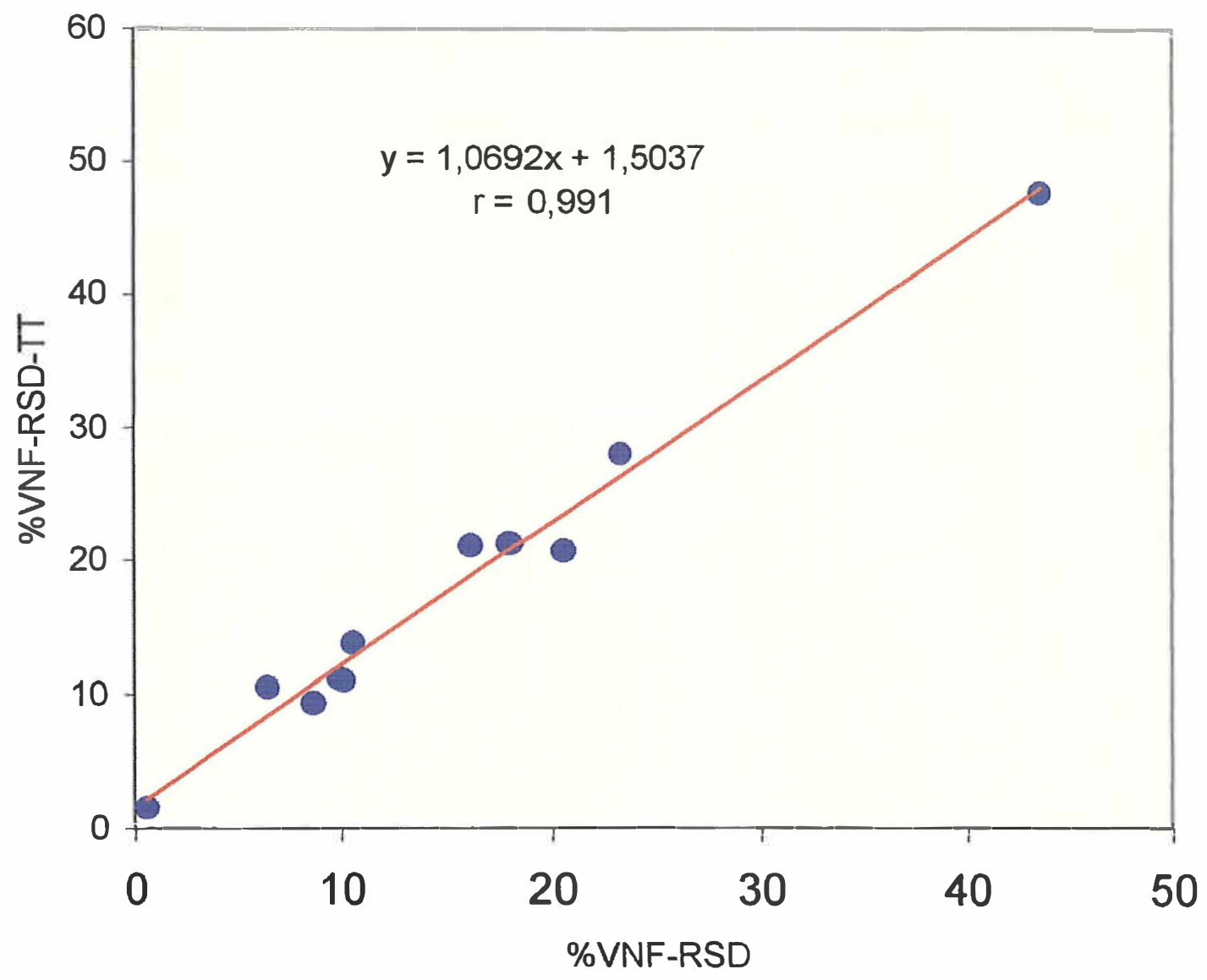

Figura 24. Relação entre a porcentagem de vasos não funcionais com $(\%$ VNF-RSD $=$ porcentagem de vasos não funcionais observada no tratamento com RSD) e sem falsos positivos (\%VNF-RSD-TT = obtida quando a porcentagem de vasos não funcionais do tratamento controle sadio foi subtraída daquela observada no tratamento controle). 


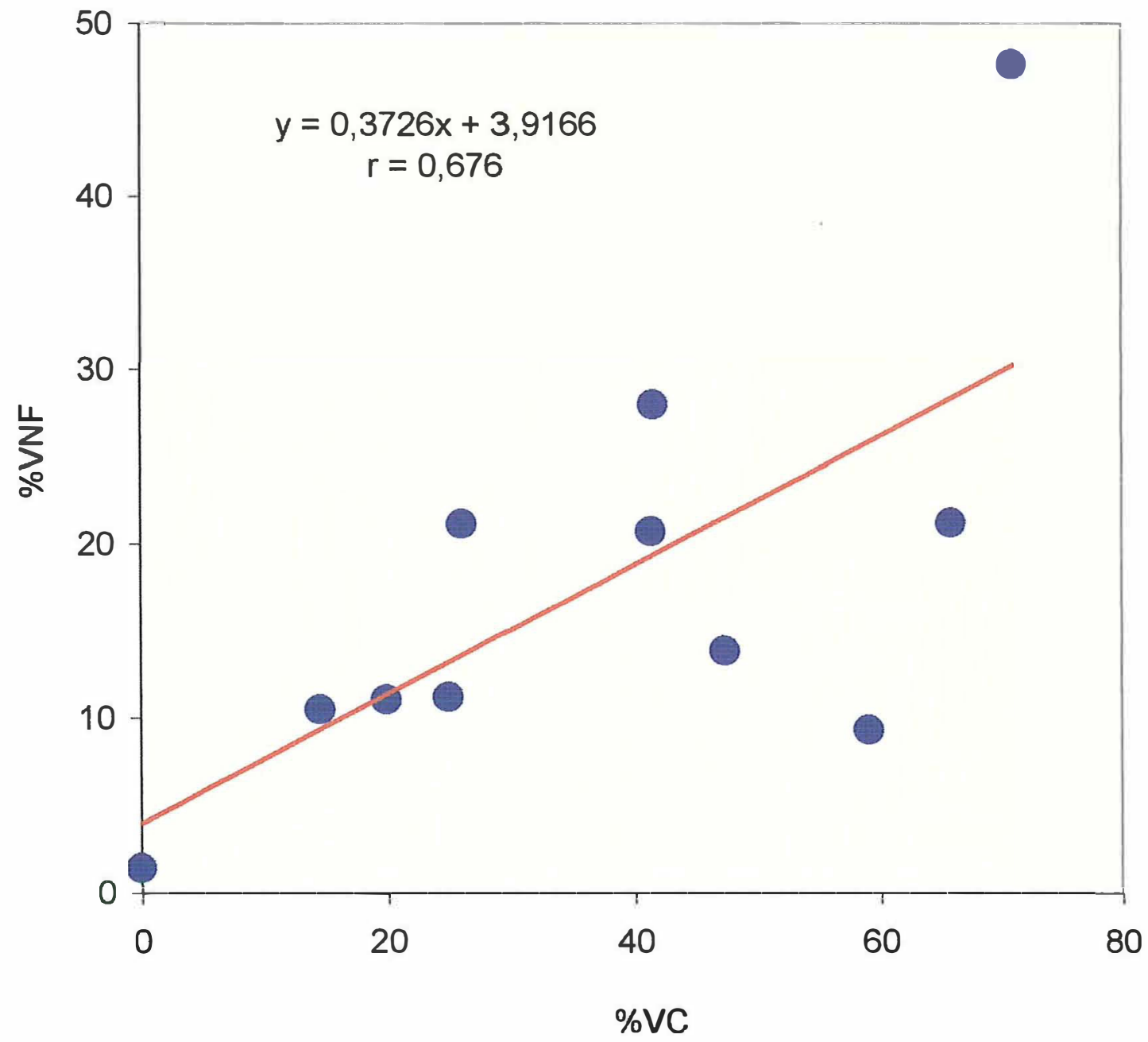

Figura 25. Relação entre colonização de colmos de cana-de-açúcar por C. $x$. subsp. xyli e entupimento dos vasos de 11 cultivares variando quanto ao nível de resistência ao $\mathrm{RSD}(\% \mathrm{VC}=$ porcentagem de vasos colonizados; \% VNF = porcentagem de vasos não funcionais). 


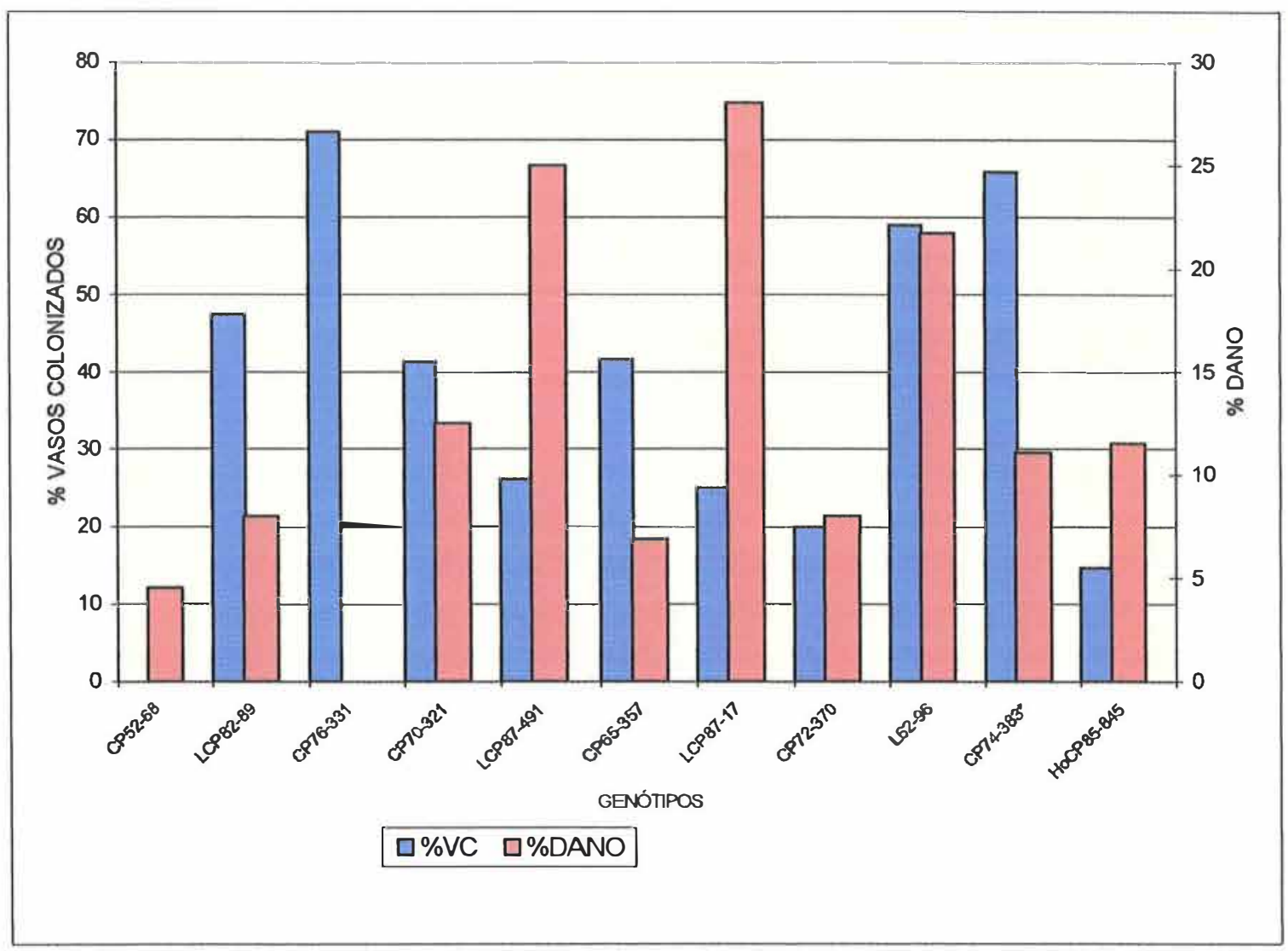

Figura 26. Porcentagem de vasos colonizados (\%VC) por Clavibacter xyli subsp. xyli e os respectivos danos causados em diferentes genótipos de cana-de-açúcar. 


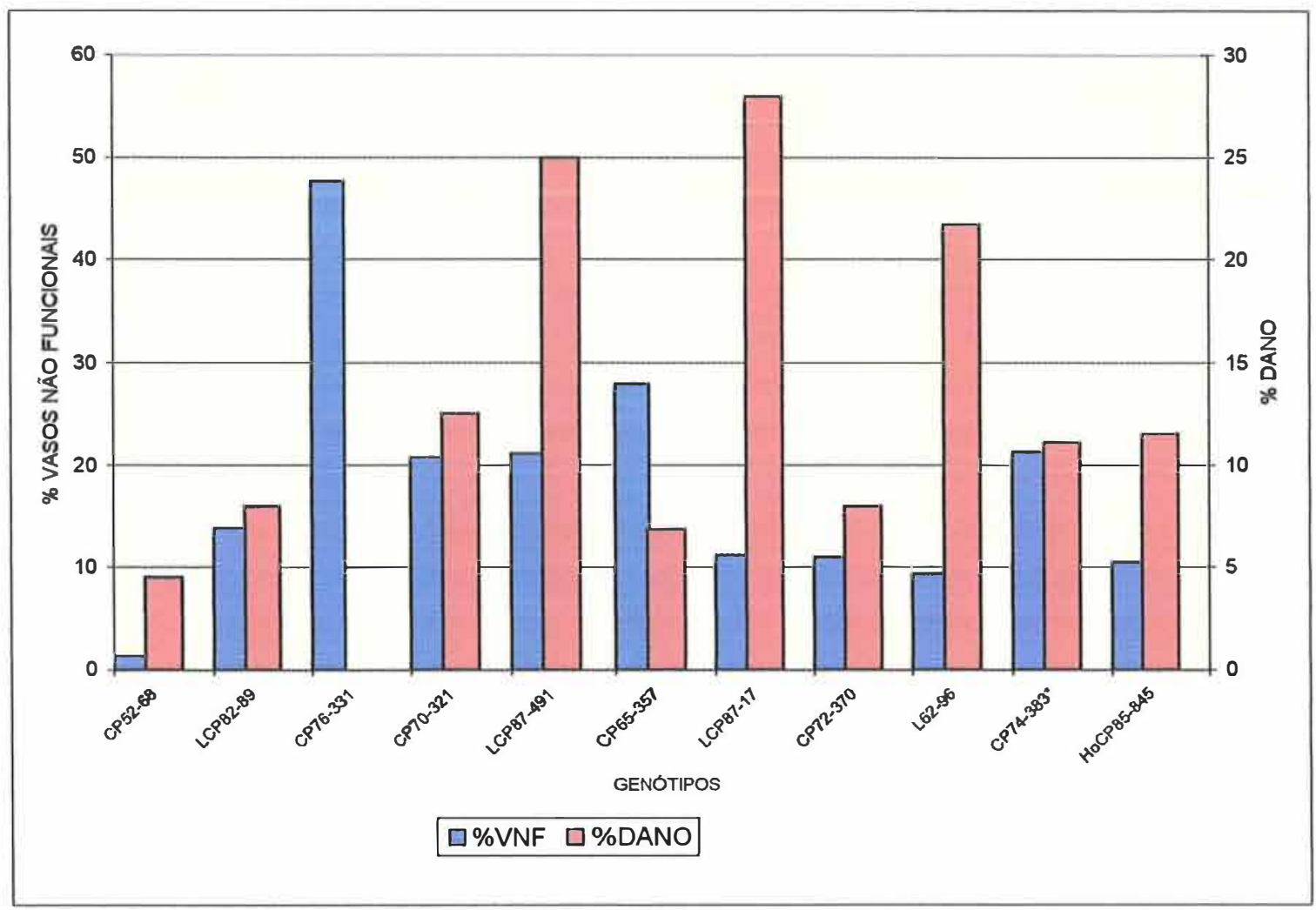

Figura 27. Porcentagem de vasos não funcionais (\%VNF) obstruídos e os respectivos danos causados em diferentes genótipos de cana-de-açúcar. 
Tabela 1. Colonização (\%VC) e entupimento (\%VNF) de vasos por C. $x$. subsp. xyli em seç̧õoes transversais de colmos de três cultivares de cana-de-açúcar diferindo em suscetibilidade ao RSD.

\begin{tabular}{lccc}
\hline \multirow{2}{*}{$\begin{array}{c}\text { Cultivar } \\
\text { estudado }\end{array}$} & \multicolumn{2}{c}{ Severidade do RSD } \\
\cline { 2 - 4 } & \%VC & \%VNF \\
\hline CP72-2086 & 7,55 & 6,42 \\
CB41-76 & 29,68 & 13,17 \\
CP53-1 & & 69,12 & 40,19 \\
\hline \multicolumn{2}{r}{ Média } & $\mathbf{3 5 , 4 5}$ & $\mathbf{1 9 , 9 3}$ \\
\hline
\end{tabular}

\footnotetext{
${ }^{\mathrm{x}}$ Média de 10 colmos

${ }^{y}$ Porcentagem de vasos colonizados

${ }^{x}$ Porcentagem de vasos não funcionais
} 
Tabela 2. Colonização e entupimento de feixes vasculares por $C$. $x y l i$ subsp. $x y l i$ em seç̧ões transversais de colmos de cana-de-açúcar.

\begin{tabular}{|c|c|c|c|c|c|c|}
\hline \multirow{3}{*}{ Cultivar } & \multicolumn{6}{|c|}{ Tamanho da amostra (área da seç̧ão transversal do colmo) ${ }^{\mathrm{X}}$} \\
\hline & \multicolumn{2}{|c|}{$\begin{array}{l}\text { PEQUENA } \\
\left(0,785 \mathrm{~cm}^{2}\right)\end{array}$} & \multicolumn{2}{|c|}{$\begin{array}{c}\text { MÉDIA } \\
\left(2,010 \mathrm{~cm}^{2}\right)\end{array}$} & \multicolumn{2}{|c|}{$\begin{array}{l}\text { GRANDE } \\
\left(3,799 \mathrm{~cm}^{2}\right)\end{array}$} \\
\hline & $\% \mathrm{VC}^{\mathrm{y}}$ & $\% \mathrm{VNF}^{\mathrm{z}}$ & $\% \mathrm{VC}$ & $\%$ VNF & $\% \mathrm{VC}$ & $\%$ VNF \\
\hline CP53-1 & 52,36 & 21,65 & 38,71 & 14,53 & 27,71 & 7,93 \\
\hline CP70-1133 & 6,77 & 3,58 & 4,44 & 2,02 & 2,76 & 1,20 \\
\hline CB49-260 & 9,66 & 5,62 & 5,56 & 4,07 & 3,16 & 2,41 \\
\hline L60-25 & 3,76 & 2,49 & 2,14 & 1,59 & 1,13 & 0,96 \\
\hline L62-96 & 18,92 & 5,27 & 13,8 & 3,00 & 8,12 & 1,83 \\
\hline CP70-321 & 34,81 & 4,24 & 21,85 & 1,93 & 13,4 & 1,14 \\
\hline CP72-356 & 33,07 & 21,53 & 17,31 & 10,04 & 13,31 & 7,53 \\
\hline CP74-383 & 78,84 & 11,69 & 61,61 & 9,38 & 44,2 & 7,24 \\
\hline Média & 29,77 & 9,51 & 20,68 & 5,82 & 14,22 & 3,78 \\
\hline
\end{tabular}

\footnotetext{
${ }^{\mathrm{x}}$ Média de 10 colmos

${ }^{y}$ Porcentagem de vasos colonizados

${ }^{x}$ Porcentagem de vasos não funcionais
} 
Tabela 3. Número total de vasos (TV) e colonização de feixes vasculares por $C$. xyli subsp. xyli em secções transversais (área $=0,785 \mathrm{~cm}^{2}$ ) de colmos de 19 cultivares de cana-de-açúcar naturalmente infectados, sendo cada um representado por 10 colmos.

\begin{tabular}{|c|c|c|c|}
\hline CULTIVAR & TV & $V C^{\mathbf{x}}$ & $\% V C^{\mathrm{y}}$ \\
\hline CP74-383 & 70,3 & 66,0 & 94,62 \\
\hline CP72-356 & 86,8 & 39,0 & 46,76 \\
\hline L62-96 & 56,4 & 29,4 & 52,27 \\
\hline CP70-321 & 69,7 & 28,8 & 41,40 \\
\hline F36-819 & 60,4 & 26,2 & 44,68 \\
\hline CP79-318 & 92,6 & 25,1 & 27,21 \\
\hline CP63-588 & 33,9 & 18,8 & 54,41 \\
\hline CP68-102 & 34,2 & 16,7 & 49,88 \\
\hline CP74-200 & 42,0 & 12,0 & 32,03 \\
\hline CB49-260 & 46,6 & 10,0 & 22,00 \\
\hline L60-25 & 49,8 & 7,9 & 16,90 \\
\hline CP52-68 & 58,0 & 7,9 & 13,15 \\
\hline CP70-1133 & 56,9 & 7,2 & 13,15 \\
\hline SP70-1143 & 52,6 & 6,6 & 11,95 \\
\hline CB41-76 & 44,3 & 6,5 & 14,60 \\
\hline CP68-1067 & 34,6 & 0 & 0 \\
\hline CB40-13 & 42,2 & 0 & 0 \\
\hline CP71-1086 & 48,9 & 0 & 0 \\
\hline CP72-2086 & 52,6 & 0 & 0 \\
\hline
\end{tabular}

${ }^{\mathrm{x}}$ Número absoluto de vasos colonizados; ${ }^{\mathrm{y}}$ Porcentagem de vasos colonizados 
Tabela 4. Número de vasos colonizados (VC) e entupidos (VNF) por $C$. $x$. subsp. $x y l i$ em uma mesma amostra de tecido central do terceiro internódio basal de colmos de nove genótipos moderadamente resistentes ao RSD.

\begin{tabular}{|c|c|c|c|}
\hline \multirow{2}{*}{$\begin{array}{c}\text { GENÓTIPOS } \\
\text { DA SÉRIE CP92 }\end{array}$} & \multicolumn{2}{|c|}{ SEVERIDADE DE RSD ${ }^{X}$} & \multirow{2}{*}{$\begin{array}{c}\text { NÍVEL DE } \\
\text { RESISTÊNCIA }^{Z}\end{array}$} \\
\hline & VC & VNF & \\
\hline 1980 & 0 & 0,40 & $\mathbf{R}$ \\
\hline 1238 & 0 & 0,80 & $\mathbf{R}$ \\
\hline 1062 & 0,25 & 1,95 & $\mathrm{R}$ \\
\hline 1150 & 0,40 & 1,50 & R \\
\hline 1880 & 0,40 & 1,50 & $\mathrm{R}$ \\
\hline 1883 & 1,40 & 1,55 & $\mathbf{R}$ \\
\hline 1924 & 3,30 & 3,10 & MR \\
\hline 1914 & 5,60 & 5,60 & MR \\
\hline 2246 & 11,30 & 9,20 & I \\
\hline
\end{tabular}

$\mathrm{X}$ Média de quatro repetições (cinco colmos por repetição)

${ }^{\mathrm{z}} \mathbf{R}=$ resistente, $M R=$ Moderadamente resistente $\mathrm{e} I=$ intermediário. 
Tabela 5. Colonização e entupimento de feixes vasculares de colmos de cana-de-açúcar por C. $x$. subsp $x y l i$ e dados históricos de danos em produção de cana por parcela

\begin{tabular}{|c|c|c|c|}
\hline $\begin{array}{l}\text { CULTIVAR } \\
\text { ESTUDADO }\end{array}$ & $\begin{array}{c}\text { VASOS } \\
\text { COLONIZADOS } \\
\text { (VC) }\end{array}$ & $\begin{array}{c}\text { VASOS NÃO } \\
\text { FUNCIONAIS } \\
\text { (VNF) }\end{array}$ & $\begin{array}{l}\% \text { DE DANO } \\
\text { (Kg/parcela) }\end{array}$ \\
\hline CP74-383 & 66,0 & 8,4 & $13,0^{*}$ \\
\hline CP72-356 & 39,0 & 17,5 & $25,0^{*}$ \\
\hline L62-96 & 29,4 & 2,8 & $18,0^{*}$ \\
\hline CP70-321 & 28,8 & 1,8 & 0* \\
\hline F36-819 & 26,2 & 12,0 & $13,8^{*}$ \\
\hline CP79-318 & 25,1 & 2,1 & $3,0 * *$ \\
\hline CP63-588 & 18,8 & 18,3 & $13,0^{* *}$ \\
\hline CP68-102 & 16,7 & 23,5 & $18,6 * *$ \\
\hline L60-25 & 7,9 & 1,6 & $13,0^{* *}$ \\
\hline CP52-68 & 7,9 & 1,3 & $1,0^{*}$ \\
\hline CP70-1133 & 7,2 & 1,8 & $5,9 * *$ \\
\hline CP68-1067 & 0 & 0,2 & $3,9 * *$ \\
\hline CP71-86 & 0 & 0,1 & $0^{* *}$ \\
\hline СР72-2086 & 0 & 1,2 & $0 * *$ \\
\hline
\end{tabular}

* Dados obtidos por Dean (1983)

** Dados obtidos por Davis et al. (1984) 
Tabela 6. Porcentagem de feixes vasculares colonizados (\%VC) e entupidos (\%VNF) por $C$. $x$. subsp. $x y l i$ e a respectiva de reação de cultivares de cana-de-açúcar ao RSD.

SEVERIDADE DE RSD (\%)

\begin{tabular}{lcccc}
\hline CULTIVAR & \multicolumn{2}{c}{ CONTROLE ${ }^{\mathbf{1}, \mathbf{2}}$} & \multicolumn{2}{c}{ RSD $^{\mathbf{3}, \mathbf{4}}$} \\
\cline { 2 - 5 } & \%VC & \%VNF & \%VC & \%VNF \\
\hline CP76-331 & 0 & 4,15 & $70,96 \mathrm{a}$ & $47,72 \mathrm{a}$ \\
CP74-383 & 0 & 3,21 & $65,78 \mathrm{a}$ & $21,31 \mathrm{~b}$ \\
L62-96 & 0 & 0,71 & $58,99 \mathrm{a}$ & $9,37 \mathrm{c}$ \\
\hline LCP82-89 & 0 & 3,28 & $47,37 \mathrm{a}$ & $13,88 \mathrm{c}$ \\
CP65-357 & 0 & 4,74 & $41,58 \mathrm{a}$ & $28,00 \mathrm{~b}$ \\
\hline CP70-321 & 0 & 0,20 & $41,41 \mathrm{a}$ & $20,77 \mathrm{~b}$ \\
\hline LCP87-491 & 0 & 4,89 & $26,09 \mathrm{~b}$ & $21,19 \mathrm{~b}$ \\
\hline LCP87-17 & 0 & 1,30 & $24,99 \mathrm{~b}$ & $11,23 \mathrm{c}$ \\
\hline CP72-370 & 0 & 0,87 & $19,94 \mathrm{~b}$ & $11,06 \mathrm{c}$ \\
\hline HoCP85-845 & 0 & 4,01 & $14,62 \mathrm{~b}$ & $10,49 \mathrm{c}$ \\
\hline CP52-68 & 0 & 0,82 & $0,00 \mathrm{c}$ & $1,45 \mathrm{~d}$ \\
\hline Média & $\mathbf{0}$ & $\mathbf{2 , 5 6}$ & $\mathbf{3 7 , 4 3}$ & $\mathbf{1 7 , 6}$ \\
\hline
\end{tabular}

1/ Segunda soca avaliada em setembro de 1995.

21 Média de três repetições.

3/ Valores de médias seguidas pela mesma letra não diferem significativamente ao nível de 5\% de probabilidade pelo teste de Scott-Knott.

4/ Sombra azul forte, leve e ausente, correspondem a genótipos suscetíveis, intermediários e resistentes ao RSD, respectivamente. 
Tabela 7. Comparação do agrupamento de cultivares quanto ao nível de resistência ao RSD pelos métodos estatísticos de Scott-Knott e Duncan.

\begin{tabular}{|c|c|c|c|c|c|c|}
\hline \multirow{2}{*}{$\begin{array}{l}\text { CULTIVAR } \\
\text { ESTUDADO }\end{array}$} & \multicolumn{3}{|c|}{$\mathrm{TBIA}^{\mathbf{1}, \underline{2}}$} & \multicolumn{3}{|c|}{ STM } \\
\hline & $\% \mathrm{VC}$ & $\begin{array}{l}\text { Scott- } \\
\text { Knott }\end{array}$ & Duncan & $\% \mathrm{VNF}$ & $\begin{array}{l}\text { Scott- } \\
\text { Knott }\end{array}$ & $\begin{array}{c}\text { Dunca } \\
n\end{array}$ \\
\hline CP76-331 & 70,96 & a & $\mathrm{AB}$ & 47,72 & $\mathrm{a}$ & $\mathrm{AB}$ \\
\hline CP74-383 & 65,78 & a & $\mathrm{AB}$ & 21,31 & b & $\mathrm{AB}$ \\
\hline L62-96 & 58,99 & a & B & 9,37 & c & B \\
\hline LCP82-89 & 47,37 & a & BCD & 13,88 & c & $\mathrm{BCD}$ \\
\hline CP65-357 & 41,58 & a & $\mathrm{BCD}$ & 28,00 & $b$ & $\mathrm{BCD}$ \\
\hline CP70-321 & 41,41 & a & $\mathrm{BCD}$ & 20,77 & b & $\mathrm{BCD}$ \\
\hline LCP87-491 & 26,09 & $\mathrm{~b}$ & $\mathrm{CDE}$ & 21,19 & $\mathrm{~b}$ & $\mathrm{CDE}$ \\
\hline LCP87-17 & 24,99 & b & $\mathrm{CDE}$ & 11,23 & c & $\mathrm{CDE}$ \\
\hline CP72-370 & 19,94 & $b$ & $\mathrm{DE}$ & 11,06 & c & $\mathrm{DE}$ \\
\hline HoCP85-845 & 14,62 & b & E & 10,49 & c & E \\
\hline CP52-68 & 0,00 & c & $\mathrm{F}$ & 1,4 & $\mathrm{~d}$ & F \\
\hline
\end{tabular}

1/'Valores de médias seguidas pela mesma letra não diferem significativamente ao nível de 5\% de probabilidade pelo teste de Scott-Knott ou Duncan.

2l Dados originais transformados pela fórmula $\operatorname{arcsen} \sqrt{(\% R S D / 100)} ; \mathbf{C V}=\mathbf{2 5 , 9 8 \mathrm { e }}$ 24,55 para $\%$ VC e \%VNF, respectivamente. 
Tabela 8. Níveis de resistência e tolerância de cultivares de cana-de-açúcar ao RSD determinados pela associação do método conciliado STM/TBIA com ensaios de produção (Yield Data Trial $=$ YDT $)$.

\begin{tabular}{|c|c|c|c|c|c|c|}
\hline \multirow{3}{*}{ CULTIVAR } & \multirow{2}{*}{\multicolumn{2}{|c|}{$\begin{array}{c}\text { STM/TBIA } \\
\text { CONCILIADO }\end{array}$}} & \multicolumn{3}{|c|}{ ENSAIOS DE PRODUÇÃO ${ }^{1}$} & \multirow{3}{*}{$\begin{array}{l}\text { TBIA/STM } \\
\text { ASSOCIADO } \\
\text { AO YDT }\end{array}$} \\
\hline & & & \multicolumn{2}{|c|}{ TCANa/ACRE ${ }^{2}$} & \multirow{2}{*}{$\frac{\text { DANO }}{(\%)}$} & \\
\hline & $\% \mathrm{VC}$ & $\%$ VNF & CONT & RSD & & \\
\hline CP76-331 & S & $S$ & 26 & 26 & 0,00 & Tolerante \\
\hline CP74-383 & S & S & 27 & 24 & $11,11^{* *}$ & Suscetível \\
\hline L62-96 & $S$ & I & 23 & 18 & $21,74^{* *}$ & Suscetível \\
\hline LCP82-89 & $\mathrm{S}$ & I & 25 & 23 & 8,00 & Tolerante \\
\hline CP65-357 & $S$ & S & 29 & 27 & 6,90 & Tolerante \\
\hline CP70-321 & S & $S$ & 24 & 21 & $12,50 * *$ & Suscetível \\
\hline LCP87-491 & I & $S$ & 28 & 21 & $25,00 * *$ & Intolerante \\
\hline LCP87-17 & I & I & 25 & 18 & $28,00 * *$ & Intolerante \\
\hline CP72-370 & I & 1 & 25 & 23 & $8,00^{*}$ & Intolerante \\
\hline HoCP85-845 & I & I & 26 & 23 & $11,54 * *$ & Intolerante \\
\hline CP52-68 & $\mathbf{R}$ & $\mathrm{R}$ & 22 & 21 & 4,55 & Resistente \\
\hline
\end{tabular}

1/ Cana-planta colhida e pesada em 08 de Novembro de 1993 (Grisham, 1994).

2! Médias de quatro repetições $($ CONT = parcelas sadias controles; $\mathbf{R S D}=$ parcelas inoculadas).

* Médias entre tratamentos dentro de cultivar difere significativamente ao nível de $5 \%$ de probabilidade.

**Médias entre tratamentos dentro de cultivar difere significativamente ao nível de $1 \%$ de probabilidade. 